\author{
Universidade de São Paulo \\ Faculdade de Filosofia, Ciências e Letras de Ribeirão Preto
}

Programa de Psicobiologia

\title{
Modelos Matemáticos e Computacionais para o Comportamento do Rato no Labirinto em Cruz Elevado
}

Julián Tejada Herrera

Ribeirão Preto

2010 



\author{
Universidade de São Paulo \\ Faculdade de Filosofia, Ciências e Letras de Ribeirão Preto \\ Programa de Psicobiologia
}

\title{
Modelos Matemáticos e Computacionais para o Comportamento do Rato no Labirinto em Cruz Elevado
}

\author{
Julián Tejada Herrera
}

Tese submetida ao Programa de Pós-Graduação em Psicobiologia da Faculdade de Filosofia, Ciências e Letras de Ribeirão Preto da Universidade de São Paulo como parte dos requisitos para a obtenção do título de Doutor em Psicobiologia.

Orientador: Antonio Roque da Silva Filho Co-orientador: Silvio Morato de Carvalho 
AUTORIZO A REPRODUÇÃO TOTAL OU PARCIAL DESTE DOCUMENTO, POR MEIO CONVENCIONAL OU ELETRÔNICO PARA FINS DE ESTUDO E PESQUISA, DESDE QUE CITADA A FONTE.

Tejada, J.

Modelos Matemáticos e Computacionais para o Comportamento do Rato no Labirinto em Cruz Elevado / Julián Tejada Herrera; orientador Antonio Roque da Silva Filho, co-orientador Silvio Morato de Carvalho.

- Riberão Preto - SP, 2010.

$81 \mathrm{p}$

Tese (Doutorado - Programa de Pós-Graduação em Psicobiologia) - Faculdade de Filosofia, Ciências e Letras de Ribeirão Preto da Universidade de São Paulo.

Labirinto em cruz elevado, conexionismo, cadeias de Markov, efeitos de fármacos, comportamento exploratório. 


\section{Julián Tejada Herrera}

\section{Modelos Matemáticos e Computacionais para o Comporta- mento do Rato no Labirinto em Cruz Elevado}

Tese submetida ao Programa de Pós-Graduação em Psicobiologia da Faculdade de Filosoa, Ciências e Letras de Ribeirão Preto da Universidade de São Paulo como parte dos requisitos para a obtenção do título de Doutor em Psicobiologia.

Banca Examinadora:

Prof. Dr. Antônio Carlos Roque da Silva

Prof. Dr. Leandro José Bertoglio

Prof. Dr. Ricardo Luiz Nunes de Souza

Prof. Dr. Renato Tinós 



\section{Resumo}

TEJADA, J.. Modelos Matemáticos e Computacionais para o Comportamento do Rato no Labirinto em Cruz Elevado. Tese (Doutorado) - Faculdade de Filosofia, Ciências e Letras de Ribeirão Preto, Universidade de São Paulo, Ribeirão Preto, 2010.

O Labirinto em Cruz Elevado (LCE) é um modelo animal para o estudo da ansiedade, suas bases biológicas e os efeitos de diferentes tipos de fármacos sobre o comportamento. Diferentes métodos têm sido usados para estudá-lo, dentro dos quais encontra-se a modelagem computacional. O presente trabalho junta-se a esses estudos utilizando as ferramentas da modelagem computacional para desenvolver dois modelos computacionais e índices que permitiram avaliá-lo.

O primeiro deles estuda a maneira como os animais exploram o labirinto usando cadeias de Markov. Esta abordagem rendeu um método de caracterização capaz de identificar os efeitos de certos tipos de fármacos sobre a maneira como o animal explora o LCE, ao mesmo tempo que levanta alguns indícios sobre a quantidade de informação que o rato usa para tomar uma decisão.

O segundo foi construído baseado na ideia do conflito como o determinante do comportamento do rato no LCE, adaptando um modelo de rede neural usado para avaliar informação conflitante: o modelo de dipolo chaveado de Grossberg. O objetivo desse segundo modelo foi avaliar a viabilidade de um modelo de competição de três forças: uma que insta explorar locais considerados amedrontadores, uma outra que insta procurar proteção e a última que representa o vigor do animal. Cada uma das forças que compõem o modelo recebe sinais vindos do ambiente e a maneira como processam esses sinais pode ser afetada pelos efeitos de um determinado fármaco.

O modelo reproduz os efeitos esperados dos três tipos de fármacos fazendo mudanças em no máximo dois de seus parâmetros. Da mesma maneira, o modelo reproduz parte do comportamento esperado na Arena, precisando apenas de um pequeno ajuste para reproduzir as trajetórias que o animal costuma fazer em torno das paredes desse labirinto.

Pode-se concluir que o modelo computacional descreve uma possível maneira de como as variáveis que controlam o comportamento do rato no LCE interagem e de como os fármacos interagem com essas variáveis, permitindo a reprodução do comportamento do rato no LCE e em outros labirintos como a Arena.

O modelo foi construído para reproduzir os efeitos de três tipos de fármacos, porém, a maneira como esses tipos de fármacos interagem com o modelo não foi condicionada a um local ou maneira específico. Esta abordagem permite procurar outras interações que não somente reproduzam os efeitos de fármacos conhecidos, mas também possam predizer os efeitos de fármacos ainda não estudados.

Palavras-chave: Labirinto em cruz elevado, conexionismo, cadeias de Markov, efeitos de fármacos, comportamento exploratório. 



\section{Abstract}

TEJADA, J.. Mathematical and Computational models of the rat behavior into the Elevated Plus Maze . Dissertation (Doctoral degree) - Faculdade de Filosofia, Ciências e Letras de Ribeirão Preto, Universidade de São Paulo, Ribeirão Preto, 2010.

The Elevated Plus Maze (EPM) is an animal model for the study of anxiety, its biological foundations, and the effects of different kinds of drugs on behavior. A group of different modeling methods have been used to study the rat behavior in the EPM. One of them characterizes rat behavior the EPM using directed graphs and proposes an index which can be used to classify the drug type and dosis. The other two methods were used to construct computational models for the rat behavior.

The first of these models used Markov chains to reproduce the rat behavior. This approach offers a method to characterize the rat behavior, which is able to identify the effects of certain kinds of drugs on the way the rat explores the maze and, at the same time, raises some clues on how much information is used by the animal to take a decision.

The second one was built based on the idea that conflict determines the rat behavior in the EPM. Conflict was introduced in the model via an adapted version of Grossberg's gated dipole artificial neural network model. The goal was to evaluate the viability of a competition-based model with three kind of drives: a drive to explore threatening places, a drive to seek protection, and a drive to move, related to the energy of the animal. The model receives and processes signals from the environment according to the states of these three drives, and the way in which the signals are processed can be influenced by effects of specific drugs.

This model reproduces the expected effects of three types of drugs with modifications of up to two parameters. The model also reproduces part of the expected behavior of the animal in the Arena, a different maze, by requiring only small adjustments to reproduce the trajectory of the rat around the walls. It is possible to conclude that this computational model captures elements of the interaction of variables which control the rat behavior in the EPM and how drugs interact with these variables. These elements may also be present in the rat behavior in the Arena.

The tools and models presented here offer new paradigms to study rat behavior in the EPM. They can offer new benchmarks to characterize rat behavior and can be used to study the effects of different drugs and their interactions.

Keywords: Elevated Plus Maze, conexionism, Markov chain, drug effects, exploration behavior. 



\section{Dedicatória}

À Kamilla 



\section{Agradecimentos}

Ao meu orientador Antônio Roque por me aceitar e me dar a oportunidade de trabalhar na área na que sempre quis trabalhar.

Ao Professor Sílvio Morato, coorientador do meu trabalho, por me oferecer sua amizade e me abrir as portas do seu laboratório.

À Professora Geraldine Bosco por seus aportes que deram um grande impulso para a realização dos estudos dos capítulos 2 e 3.

Ao Rodrigo Oliveira, por acreditar em mim e me acolher, este projeto não tivesse começado sem seu apoio.

À Cristiane Salum por ter construído o primeiro modelo e por todas suas contribuições como avaliadora do meu trabalho que continua seu legado.

Aos meus colegas do laboratório: Janaína, Denise, André, Lucas, Diogo, Rodrigo P, Carlos, Pedro, Tiago, Rafael e recentemente Misael, por compartilhar discussões, brincadeiras, cafés e o dia a dia no laboratório.

Aos meus colegas do laboratório do Sílvio: Aninha, Carol, Milena, Javier e Thiago por me abrir um espaço no laboratório e suportar as excentricidades da minha paixão pelo Linux.

Aos funcionários da USP, Renata Vicentini Del Moro, Maria Inês Joaquim, Paulinho Castrechini cujo profissionalismo contribuiu na consolidação deste trabalho.

Aos estudantes do laboratório de Sílvio: Milena, Ana, Javier e Tulio quem amavelmente facilitaram para mim os registros de seus animais, sem os quais não tivesse conseguido consolidar os estudos de caraterização.

À Kamilla por me acolher no seu país, na sua família e no seu coração.

Aos Colombianos, Milena, Claudia, Mariandrés, Javier, Omar, Guillermo, Astrid, Rogelio, e um grande etc. por sua amizade e apoio. E em especial a Lina que compartilhou comigo os primeiros anos do meu doutorado.

Agradeço aos meus pais que sempre tem me brindado seu apoio e compreensão.

Ao restante de minha família, em especial a meu irmão que ajudou minha família em quanto eu estava por aqui estudando.

À Jenny, à Yohanna, à Aleja e à Sol, por seu apoio e cumplicidade. 
Ao Arturo Clavijo e ao Juan Oliveros, grandes amigos com os que sempre pude contar apesar da distância.

A todos meus amigos e amigas em Colômbia.

A todos os brasileiros em geral, porque sempre tem sido uma grata surpresa conhece-los, por sua alegria e sua capacidade de me fazer sentir em casa.

A todas as pessoas no Brasil e na Colômbia que de uma ou outra maneira tem contribuído ao presente trabalho.

À Fundação de Amparo à Pesquisa do Estado de São Paulo (FAPESP) pelo apoio financeiro. 


\section{Sumário}

Resumo

p. vii

Abstract

p. ix

Lista de Siglas

p. iii

Lista de Figuras

p. V

Lista de Tabelas

p. xi

1 Introdução $\quad$ p. 1

1.1 O que faz o rato no interior do LCE e como isso é medido ....... p. p. 2

1.2 Modelos computacionais para o comportamento do rato no LCE ..... p. 4

2 Caracterização do comportamento do rato no LCE usando grafos direcionados p. 11

2.1 Método . . . . . . . . . . . . . . . . . . . . . . . . . . . . p. 12

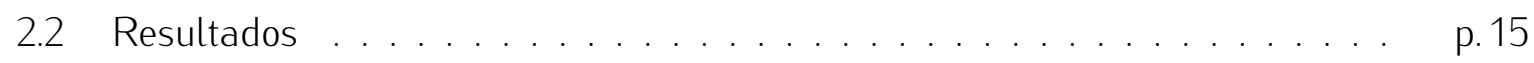

2.3 Discussão . . . . . . . . . . . . . . . . . . . . . . . . . p. 21

3 Caracterização do comportamento do rato no LCE com cadeias de Markov p. 23

3.1 Método . . . . . . . . . . . . . . . . . . . . p. 23

3.2 Resultados ... . . . . . . . . . . . . . . . . . . . p. 30

3.3 Discussão . . . . . . . . . . . . . . . . . . . . . . . . . . p. 35

4 Modelo conexionista para o comportamento exploratório do rato p. 39

4.1 Descrição do modelo . . . . . . . . . . . . . . p. 40 
4.2 Método . . . . . . . . . . . . . . . . . . . . p. 46

4.2 .1 Ajuste do modelo . . . . . . . . . . . . . . . . p. 47

4.2.2 Identificação dos parâmetros cujas mudanças representam efeitos

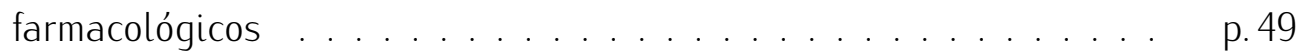

4.2 .3 Teste do modelo na Arena ... . . . . . . . . . . . . . p. 49

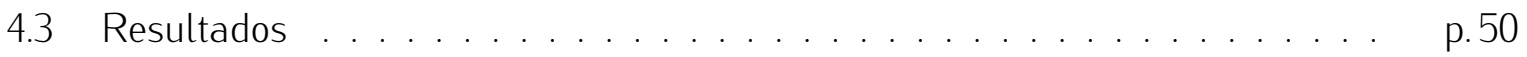

4.3.1 Labirinto em Cruz Elevado . . . . . . . . . . . . . . . p. 50

4.3 .2 Arena. . . . . . . . . . . . . . . . . . . . p. 56

4.4 Discussão . . . . . . . . . . . . . . . . . . . . . . . p. 60

5 Conclusões finais $\quad$ p. 65

Apêndice $A$ - Cálculo do índice de atividade exploratória $\quad$ p.69

$\begin{array}{ll}\text { Apêndice } B-\text { Cálculo dos vetores de valores de } \pi & \text { p.71 }\end{array}$

B.1 Cálculo solucionando o sistema de equações . . . . . . . . . . . . . p.71

B.2 Cálculo multiplicando a matriz estocástica f . . . . . . . . . . p.72

Apêndice C - Relação dos valores dos parâmetros usados no modelo do LCE e $\begin{array}{ll}\text { da Arena p.75 } & \text { p. }\end{array}$

$\begin{array}{ll}\text { Referências } & \text { p.77 }\end{array}$ 


\section{Lista de Siglas}

AG Algoritmos genéticos

AIC Akaike's Informationn Criterion

ANOVA Analise de Variância

BIC Bayes Information Criterion

CDP Clordiazepóxido

CTRL Grupo Controle

LCE Labirinto em cruz elevado

LCEF Labirinto em cruz elevado com todos os braços fechados

MDZ Midazolam

PTZ Pentilenotetrazol

SCZ Semicarbazida 


\section{Lista de Figuras}

2.1 (a) Esquema do LCE apresentando as divisões do piso em quadrados e as possíveis transições que o animal pode realizar ao se movimentar de um quadrado para outro. (b) Detalhe de três quadrados vizinhos (nós) mostrando as possíveis transições que do nó $i$ se pode fazer para os nós vizinhos $j$ e $k$.

2.2 A figura mostra como foi construída a representação reduzida do LCE: (a) o braço aberto direito foi rebatido ao redor do quadrado central sobre o braço aberto esquerdo, (b) o braço fechado superior foi rebatido ao redor do quadrado central sobre o braço fechado inferior. (c) A representação reduzida do LCE que consiste em um único braço aberto e um único braço fechado. (d) Para a contagem das transições considerou-se que os quadrados nos braços abertos rebatidos tiveram o mesmo número atribuido aos correspondentes quadrados nos braços não rebatidos.

2.3 Frequências (a) e tempo de permanência (b) de cada uma das possíveis transições que o rato pode fazer no LCE rebatido, com as ordenadas organizadas da maior para a menor para cada uma das condições experimentais. As barras de erro indicam a média do erro padrão. Os números sob as barras pretas (braços fechados), cinzas (braços abertos) e brancas (centro) indicam a posição do quadrado no labirinto rebatido. As setas, que são duas por cada quadrado, indicam se o rato estava indo em direção aos braços fechados (seta apontando para a esquerda) ou em direção aos braços abertos (seta apontando para direita) quando fez a transição. Por último, a linha contínua representa a curva obtida com o melhor ajuste da função de lei de potência. 
2.4 Gráfico de cada um dos valores de $k$ para cada grupo farmacológico e sua respectiva dosagem. No eixo $x$ a condição farmacológica varia da droga ansiogênica com a mais alta dosagem para a droga ansiogênica com a mais baixa, passando pelo grupo controle e terminando com os dois grupos de drogas ansiolíticas. A altura de cada barra indica o valor de $k$. . . . . .

2.5 Porcentagem de entradas e tempo de permanência nos braços abertos. As barras indicam a porcentagem (calculadas respectivamente a partir do total de entradas em ambos os tipos de braços e do total de tempo gasto em toda a sessão). As barras de erro representam o erro padrão e os asteriscos diferenças significativas quando comparados com o grupo controle (Duncan, $P<0,05)$.

3.1 Valores de probabilidade de transitar para cada um dos possíveis estados da cadeia de Markov do exemplo dado no texto, representados numa tabela (a) e como uma matriz estocástica $\mathbb{P}$ (b).

3.2 Modelo de Cadeia de Markov para a simulação do comportamento do rato no LCE. Cada número representa o local onde o organismo pode se encontrar num dado momento, as setas representam para onde ele pode-se deslocar.

3.3 Matriz estocástica que contém as probabilidades de que o animal transite de uma posição $i$ (filas) para outra posição $j$ (colunas) dentro do LCE rebatido. p. 26

3.4 Matriz estocástica com as probabilidades de transição calculadas para o grupo controle.

3.5 Matriz estocástica com as probabilidades de transição calculadas para o grupo tratado com PTZ $30 \mathrm{mg} / \mathrm{kg} . \ldots \ldots$. . . . . . . . . . . . . . . . . 31

3.6 Matriz estocástica com as probabilidades de transição calculadas para o grupo tratado com CDP.

3.7 Valores de $\pi$ calculados para cada um dos estados (posições dentro do LCE rebatido) de três grupos farmacológicos, PTZ 30 mg/kg, Controle e CDP 5 $\mathrm{mg} / \mathrm{kg}$.

3.8 Média e erro padrão das entradas nos braços abertos (a) e fechados (b) para as sete condições farmacológicas diferentes calculados usando os dados experimentais e os simulados. 
3.9 Média e erro padrão dos deslocamentos nos braços abertos (a) e fechados (b) para as sete condições farmacológicas diferentes calculados usando os dados experimentais e os simulados.

4.1 (a) Esquema original da rede de dipolo chaveado de Grossberg. (b) Esquema modificado que foi utilizado para modelar o sistema emocional. A entrada $A$ no esquema modificado representa a motivação para se deslocar na direção aos locais considerados aversivos, S representa a motivação para se movimentar em direção aos locais considerados seguros, o termo energia representa o vigor do rato e o termo / representa a informação vinda do ambiente. . . . . . . . . . . . . . . . . . . . . . .

4.2 Representação das posições instantânea, passada e (possivelmente) futura do rato. A seta representa a direção na qual o animal transita num dado momento, indicando que o rato esteve na posição 10 (denominada $x-1$ ) antes de visitar a 9 (denominada de $x$ ), ficando a posição 8 na direção do movimento (denominada de $x+1$ ).

4.3 Discretização do espaço na Arena (a) e no LCE (e). Em b, c, d, f e g são apresentadas as atribuições de zona segura (quadrados cinza) ou zona amedrontadora (quadrados brancos) a cada um dos locais ao redor da posição que o organismo ocupa atualmente (representado no diagrama por uma seta que aponta na direção da cabeça do organismo). As figuras b, c e d representam as configurações de zonas para 3 locais da Arena: perto de um canto (b), encostado numa parede (c), e em direção ao centro (d). As figuras $f$ e $g$ mostram dois locais diferentes dentro do LCE: dentro dos braços fechados (f) e dentro dos braços abertos (g).

4.4 Esquema do LCE rebatido. Os quadrados numerados de 1 a 5 (cor cinza) representam os braços abertos. Os quadrados numerados de 7 a 11 (cor preta) representam os braços fechados, e o quadrado de número 6 representa a área central do labirinto. . . . . . . . . . . . . . . . . . . p. . . 46 
4.5 Gráficos que apresentam o padrão de exploração de animais controle reais (a e b) e simulados (c, d e e) submetidos ao LCE. Os números no eixo $x$ representam cada um dos 11 quadrados nos quais foi dividido o labirinto. No eixo y se identifica se o deslocamento foi feito no piso ou nas paredes. Os pontos na linha do piso representam uma visita do animal ao respectivo quadrado e os pontos na linhas das paredes, representam uma exploração feita a uma parede ou a uma borda. As cores representam o momento no qual acontecera a exploração, sendo azuis para as primeiras explorações, verde para aquelas que aconteceram na metade da sessão e vermelha para as que aconteceram no final.

4.6 (a) Matriz estocástica com as probabilidades de transição calculadas para um grupo de 20 animais simulando uma situação controle. (b) Valores de $\pi$ calculados a partir da matriz estocástica, para cada um dos 11 locais nos que foi dividido o LCE rebatido.

4.7 Gráfico de barras comparando (a) número de entradas, (b) porcentagem de tempo de permanência e (c) cruzamentos no labirinto rebatido de três grupos farmacológicos simulados: grupo controle, grupos submetido a drogas ansiogênicas (Limiars VB + energia VB ) e grupos submetido a drogas ansiolíticas ( $A$ VA). Os asteriscos representam diferenças significativas ( $\mathrm{p}$ $0,05)$ calculadas com uma ANOVA de uma via $\left(g l_{[2 ; 57]}\right)$.

4.8 Valores de $\pi$ calculados para três simulações que representam os efeitos de drogas ansiolíticas (Esquerda VA), ansiogênicas (Limiars VB + energia VB) e um grupo controle todos submetidos ao labirinto rebatido.

4.9 Gráficos que apresentam o padrão de exploração de animais controle reais (a e b) e simulados (c, e d) submetidos à Arena. Os números nos eixos $x$ e $y$ representam as paredes $(P)$ e cada um dos 6 quadrados nos quais foi dividido a Arena. Os pontos representam uma visita do animal ao respectivo quadrado ou uma exploração feita a uma parede $(\mathrm{P})$. As cores indicam o momento no qual acontecera a exploração, sendo azuis para as primeiras explorações, verde para aquelas que aconteceram na metade da sesão e vermelha para as que aconteceram no final. 
4.10 Gráficos que apresentam o padrão de exploração de organismos simulados na Arena com o conjunto de parâmetros obtido na procura da "exploração circular". Os números no eixo x e y representam as paredes $(P)$ e cada um dos 6 quadrados nos quais foi dividido o labirinto. Os pontos representa uma visita do animal ao respectivo quadrado ou uma exploração feita a uma parede $(\mathrm{P})$. As cores indicam o momento no qual acontecera a exploração, sendo azuis para as primeiras explorações, verde para aquelas que aconteceram na metade da sesão e vermelha para as que aconteceram no

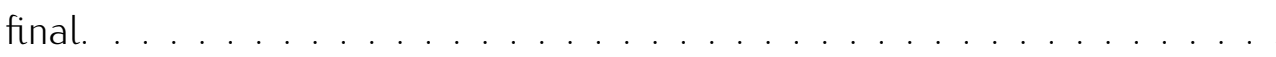

4.11 Valores dos parâmetros obtidos após a exploração com AG tendo como função de ajuste o LCE ou a Arena. . . . . . . . . . . . . . . . . . . . p. 61

B.1 Resultado da multiplicação da matriz estocástica em (a) um número par de vezes e em (b) um número ímpar. 


\section{Lista de Tabelas}

2.1 Número de ratos, tratamento farmacológico e dosagem para cada um dos grupos experimentais.

2.2 Funções utilizadas no processo de procura do melhor ajuste.

2.3 Valores de qui-quadrado reduzido, coeficiente de correlação (entre $\ln f$ e $\ln R)$ e os parâmetros da lei de potência com os quais se ajustou cada grupo experimental. Os asteriscos representam valores significativos. . . .

2.4 Coeficiente de correlação de Pearson entre o expoente $k$ da lei de potência e as medidas comportamentais. Os coeficientes foram calculados a partir da informação obtida para cada rato $(N=130)$. r, coeficiente de correlação; $P, \mathrm{p}$-value.

3.1 Valores de $\pi$ calculados para cada um dos estados (posições dentro do LCE rebatido) e para cada um dos tratamentos farmacológicos.

3.2 Valores do logaritmo da razão de verossimilhança do teste de independência para todas as condições farmacológicas. Todos os valores são superiores ao valor de prova para uma distribuição $\chi^{2}$ com 11 graus de liberdade $\left(\chi_{[121 ; 0,95]}^{2}=147,67\right)$.

3.3 Valores de $A I C$ e $B I C$ calculados, fixando $m=3$, a partir dos dados de cada uma das diferentes condições farmacológicas.

3.4 Valores de $\eta_{k, m}$ calculados fixando $m=3$, a partir dos quais foram calculados os índices $A / C$ e $B / C$.

3.5 Valores do estimador de máxima verossimilhança para todas as condições farmacológicas, calculados fixando como máxima ordem 2. Todos os valores possuem uma probabilidade superior a 0,05 para uma distribuição $\chi^{2}$ com $s^{m}(s-1)-s^{l}(s-1)$ graus de liberdade.

4.1 Relação de parâmetros do modelo que foram ajustados com os algoritmos genéticos 
4.2 Resultados dos testes $t$ para diferenças de médias de entradas nos braços do labirinto rebatido, calculados entre um grupo de 20 ratos simulando condições controle (Ctrl) e um grupo de 20 ratos simulados a partir de conjuntos diferentes de parâmetros (Expl). Cada um dos conjuntos teve mudanças nos valores dos parâmetros especificados na primeira coluna. As modificações podiam ser VA para valores altos do parâmetro ou VB para valores baixos. . . . . . . . . . . . . . . . . . . . . . . .

4.3 Resultados dos testes $t$ para diferenças de médias da porcentagem de tempo de permanência nos braços do labirinto rebatido, calculados entre um grupo de 20 ratos simulando condições controle $(\mathrm{Ctrl})$ e um grupo de 20 ratos simulados a partir de conjuntos diferentes de parâmetros (Expl). Cada um dos conjuntos teve mudanças nos valores dos parâmetros especificados na primeira coluna. As modificações podiam ser VA para valores altos do parâmetro ou VB para valores baixos.

4.4 Resultados dos testes $t$ para diferenças de médias dos cruzamentos no labirinto rebatido, calculados entre um grupo de 20 ratos simulando condições controle (Ctrl) e um grupo de 20 ratos simulados a partir de conjuntos diferentes de parâmetros (Expl). Cada um dos conjuntos teve mudanças nos valores dos parâmetros especificados na primeira coluna. As modificações podiam ser VA para valores altos do parâmetro ou VB para valores baixos.

4.5 Índice que avalia a atividade exploratória e o nível de ansiedade do rato no LCE, calculado para 10 amostras de animais simulados a partir de cada um dos parâmetros explorados. Cada amostra simulava um grupo de 10 ratos. p. 56

4.6 Valor médio do índice $\pi \pm 0$ erro padrão, calculados para cada uma das 11 posições nas quais foi dividido o labirinto rebatido e para cada uma das mudanças dos parâmetros. Cada amostra representa um grupo de 10 ratos.

4.7 Média de cruzamentos e porcentagem de tempo gasto na Arena de 20 ratos simulados sob diferentes conjuntos de parâmetros. Cada conjunto de parâmetros teve alguma modificação no parâmetro especificado na primeira coluna. As modificações podiam ser VA para valores altos do parâmetro ou VB para valores baixos.

C.1 Relação dos valores dos parâmetros achados com AG para o modelo do LCE e da Arena 


\section{Introdução}

O Labirinto em Cruz Elevado (LCE) é um teste comumente utilizado para o estudo da ansiedade em animais, suas bases biológicas e os efeitos de diferentes tipos de drogas sobre o comportamento do animal (Handley e Mithani, 1984; Salum, Roque e Morato, 2000; Walf e Frye, 2007). Ao mesmo tempo é utilizado em outra gama de estudos que incluem aprendizagem, memória, dor e dependência às drogas (Carobrez e Bertoglio, 2005). O LCE é composto por dois braços abertos e dois braços fechados, cruzados em ângulo reto, conectados por uma área central. O conjunto todo está elevado a $50 \mathrm{~cm}$ do piso. É muito popular por sua facilidade de utilização já que não requer privação ou treinamento do animal e, além disso, é possível observar os efeitos de diferentes drogas no comportamento do animal (Carobrez e Bertoglio, 2005).

O comportamento padrão de um rato no LCE é o de explorar e permanecer por mais tempo nos braços fechados. Desta maneira uma droga que incremente a exploração dos braços abertos poderia ser considerada ansiolítica, e outra que diminua a exploração dos braços abertos ou que confine o animal nos braços fechados poderia ser considerada ansiogênica. Teoricamente, acredita-se que o comportamento do animal submetido ao LCE é controlado pela confrontação entre duas tendências: uma delas incita o animal a explorar um ambiente novo e a outra a procurar proteção. Uma tendência, ou motivação, levaria o animal a explorar e a outra tendência o levaria a evitar a exploração e a permanecer num local seguro. A confrontação entre essas duas tendências pode ser vista nos primeiros minutos de uma sessão.

Os mecanismos que controlam o comportamento do animal no LCE têm sido amplamente estudados, e algumas hipóteses têm sido descartadas. Por exemplo, é sabido que não é a altura que provoca a aversão pelos braços abertos (Treit, Menard e Royan, 1993). Sabese também que a informação visual prevalece sobre a tátil, já que ratos dos quais foram retiradas as vibrissas apresentaram a mesma aversão que ratos controle (Cardenas, Lamprea e Morato, 2001) e ratos submetidos ao LCE em condições de baixa luminosidade exploram mais os braços abertos que ratos controle (Garcia, Cardenas e Morato, 2005). Também é conhecido que não é a ausência de paredes em si o que provoca a aversão pelos braços 
abertos, pois ratos submetidos a uma modificação do LCE na qual nenhum dos braços tinha paredes apresentaram o mesmo padrão de exploração que ratos submetidos a uma outra modificação do LCE na qual todos os braços tinham paredes (Salum, Roque e Morato, 2003). Por isso acredita-se que o que produz a aversão pelos braços abertos é o contraste entre os braços fechados e os abertos (Salum, Roque e Morato, 2003).

O LCE é um labirinto amplamente estudado e utilizado em uma grande quantidade de trabalhos publicados (em torno de 3256 no site do PuMed - http://www.ncbi.nlm. nih.gov/sites/entrez, em 2009; e em torno de 4286 no site do Web of Science - http: //apps.isiknowledge.com, em 2009). A grande maioria deles segue um modelo de pesquisa tradicional com animais, porém um pequeno número faz uso de um outro tipo de metodologia para abordar o estudo do LCE: a modelagem computacional. O objetivo desta metodologia é construir um modelo matemático cuja simulação computacional seja capaz de reproduzir aspectos do comportamento em questão. Em geral, o modelo matemático envolve relações funcionais entre suas variáveis tão complexas que tornam inviáveis o seu estudo de maneira puramente analítica, e é por isso que a sua simulação computacional torna-se necessária.

Um modelo computacional deve incluir definições apropriadas de cada uma das variáveis utilizadas, que se acredita estarem envolvidas no controle do comportamento do animal, e, da mesma maneira, uma definição específica do modo pelo qual essas variáveis interagem. Essa abordagem oferece um controle total sobre as variáveis envolvidas, ao mesmo tempo em que oferece a possibilidade de avaliar a relevância que cada uma das variáveis tem sobre o comportamento. O que se pretende com este tipo de modelagem é obter informação que permita entender a maneira como as variáveis que supostamente controlam o comportamento interagem, e ainda oferecer insights que orientem novos experimentos com animais ou que permitam avaliar melhor os resultados de experimentos tradicionais. Partindo desse ponto de vista, o objetivo desta tese é desenvolver um modelo computacional para o comportamento do rato submetido ao LCE. Como ponto de partida, nas seções a seguir serão feitas discussões sobre dois aspectos importantes para este trabalho: o primeiro é o que faz o animal dentro do LCE e como isso é registrado; e o segundo é como o comportamento do rato no LCE foi simulado computacionalmente em trabalhos anteriores.

\subsection{O que faz o rato no interior do LCE e como isso é medido}

O comportamento padrão de um rato no interior do LCE é permanecer por mais tempo nos braços fechados e fazer mais entradas neles do que nos braços abertos (Pellow et al., 
1985). Ambos os comportamentos podem ser afetados por drogas. Por exemplo, se uma droga faz o rato permanecer por mais tempo nos braços abertos ou incrementa suas entradas nesses braços pode-se considerá-la como uma droga ansiolítica; da mesma maneira, se uma droga diminui o número de entradas ou o tempo que o animal permanece nos braços abertos pode-se considerá-la como ansiogênica (Pellow et al., 1985; Prut e Belzung, 2003; Carobrez e Bertoglio, 2005). Devido a isso as duas medidas mais utilizadas para caracterizar o comportamento do animal no interior do LCE são o tempo gasto e o número de entradas em cada braço (Morato, 2006; Walf e Frye, 2007). Diferentes métodos têm sido utilizados para validar essas duas medidas, por exemplo, através de analise fatorial foi demonstrado que a porcentagem de tempo gasto e o número de entradas se correlacionam bem com os efeitos de drogas (Cruz, Frei e Graeff, 1994; Rodgers e Johnson, 1995; Anseloni e Brandão, 1997). Nesses estudos a porcentagem de tempo gasto e o número de entradas nos braços abertos se agrupam num único fator e com sinal oposto ao do tempo gasto nos braços fechados que também se agrupa no mesmo fator.

Além do comportamento de deslocamento também são registrados outros comportamentos como a exploração vertical das paredes, a exploração da borda dos braços abertos quando o animal coloca sua cabeça para fora, comportamentos de avaliação de risco como o congelamento ou a exploração sigilosa esticando o corpo, e outros comportamentos como se limpar e a quantidade de fezes. Muitos desses comportamentos também são afetados pelas drogas e são utilizados como medidas do nível de ansiedade.

Todos esses comportamentos são registrados identificando o local e o momento no qual aconteceram. O espaço do labirinto é dividido em três zonas, braços abertos, braços fechados e o centro, e os comportamentos são contabilizados discriminando cada par de braços como uma única zona. Seguindo esse esquema, não interessa se um comportamento acontece no braço aberto da direita ou da esquerda ou se acontece no extremo ou perto do centro de um braço aberto; em qualquer desses casos, o registro é feito como relativo apenas aos braços abertos. O mesmo se dá com relação à quantificação temporal: ao fim de uma sessão de 5 minutos, contabiliza-se apenas o tempo gasto pelo animal em cada uma das três zonas.

Tal agrupamento espacial e temporal tem-se mostrado prático no momento de avaliar os efeitos de diferentes tipos de drogas, porém ele impede que se tenha uma ideia mais detalhada sobre como se dá a exploração do rato dentro de cada uma das três zonas, em particular nos braços abertos e fechados, ao longo de uma sessão. As possíveis diferenças entre os padrões de exploração em cada tipo de braço podem fornecer novos indicadores sobre o comportamento do rato que sejam relevantes para o seu entendimento. Por exemplo, 
no primeiro minuto de sessão o animal apresenta uma alta frequência de comportamentos de avaliação de risco e um número similar de entradas tanto nos braços fechados como nos braços abertos (Holmes e Rodgers, 1998; Bertoglio e Carobrez, 2002; Frussa-Filho e Ribeiro, 2002). Da mesma maneira, no final da sessão o rato apresenta uma redução da atividade motora que se associa a uma habituação ao labirinto (Rosa et al., 2000; Frussa-Filho e Ribeiro, 2002). No que respeita a dinâmica espacial, também há diferenças no local onde acontecem os comportamentos. Por exemplo, os comportamentos de avaliação de risco são mais frequentes nas regiões dos braços fechados mais próximas do centro (Dawson e Tricklebank, 1995).

Esse tipo de detalhes sobre a maneira como o rato se comporta é importante para a construção de simulações computacionais da sua atividade exploratória. Uma tal simulação não tem por objetivo apenas gerar variáveis estatísticas globais comparáveis àquelas medidas experimentalmente, como o número de entradas e o tempo gasto em cada uma das três zonas, mas também reproduzir de maneira mais fina a atividade exploratória do animal no ambiente em que se encontra. Somente constrangendo-se mais os modelos computacionais com detalhes observacionais e experimentais, impondo-se que os modelos reproduzam esses detalhes, é que se poderá selecionar melhores modelos e capazes de fornecer previsões testáveis.

Assim, surge a necessidade de se encontrar medidas que contenham mais detalhes sobre o comportamento do animal do que as medidas tradicionais, capazes de caracterizar de maneira mais fina esse comportamento e de fornecer uma riqueza maior de informações para a construção de simulações computacionais. Neste sentido, a primeira contribuição desta tese foi a proposta de uma nova medida para caracterizar o comportamento do animal no LCE. Essa nova medida resume em um índice o perfil de movimentação do animal no interior de um tipo de braço do LCE, o qual é sensível ao nível de ansiedade do animal. Essa nova medida é apresentada em detalhes no Capítulo 2. A partir dessa medida e das informações sobre a movimentação do rato no interior do LCE que tiveram que ser registradas para a sua validação, construiu-se um modelo computacional capaz de reproduzir o comportamento exploratório do animal no LCE. Esse modelo é baseado em cadeias de Markov e é apresentado no Capítulo 3.

\subsection{Modelos computacionais para o comportamento do rato no LCE}

Até o momento, segundo uma análise exaustiva das publicações na área feita durante a preparação desta tese, são três os modelos computacionais propostos para o comportamento 
do rato no LCE (Salum, Roque e Morato, 2000; Giddings, 2002; Miranda et al., 2009). Cada um deles realça um aspecto importante dos mecanismos hipotéticos que controlam o comportamento de ratos e camundongos submetidos ao LCE. Dentre eles, destaca-se o modelo de Salum et al. (Salum, Roque e Morato, 2000) por oferecer uma predição do comportamento de ratos sob condições nunca antes estudadas: um LCE sem paredes em nenhum dos braços e um LCE com paredes em todos os braços. Sob essas condições o rato não apresenta uma preferência clara por algum dos braços. Essa previsão feita pelo modelo e observada experimentalmente (Salum, Roque e Morato, 2003) apóia a ideia de que é o contraste entre os braços abertos e fechados que gera o conflito para o animal.

Cada um dos três modelos existentes aborda o problema do comportamento do rato no LCE de maneira diferente. O modelo de Salum et al. (Salum, Roque e Morato, 2000) põe ênfase no conflito e o operacionaliza como uma diferença entre duas variáveis. Por sua vez, o modelo de Giddings (Giddings, 2002) enfatiza a direção do movimento, considerando que a direção em que o animal se move num dado momento incita-o a continuar nela. Por último, o modelo de Miranda et al. (Miranda et al., 2009) considera quatro diferentes tipos de informações sensoriais e suas possíveis influências sobre o comportamento do rato no LCE.

Cada um dos modelos descreve o labirinto de uma maneira particular, enfatizando aspectos diferentes. O modelo de Salum et al. (Salum, Roque e Morato, 2000) foi construído baseado na ideia de que o comportamento do rato no LCE é controlado pela competição entre três forças. A primeira delas incita o organismo a explorar, a segunda o incita a se afastar dos locais considerados aversivos e a última produz mudanças aleatórias na direção dos deslocamentos. A interação entre essas três forças determina a direção na qual o organismo vai se movimentar num dado momento. Esse modelo trabalha com uma representação discreta do labirinto dividindo o piso e as paredes do mesmo em pequenos quadrados de aproximadamente o tamanho do animal (5 quadrados por braço). Isso permite localizar o animal num dado momento identificando o quadrado que ele está ocupando. Isso também torna possível a caracterização de diferentes tipos de comportamento além dos deslocamentos, já que a exploração que o animal faz nos quadrados que representam as paredes é considerada como uma exploração vertical ou "rearing" e a exploração que ele faz nos quadrados que representam o vazio ao redor dos braços abertos é tratada como a que o animal faz quando coloca a cabeça para fora da borda dos braços ou "head dipping".

A representação discreta do labirinto também ajuda a delimitar quais zonas o organismo considera interessantes para serem exploradas e quais ele considera amedrontadoras para serem evitadas. Segundo o modelo, todos os locais $i$ do labirinto possuem um valor $M_{i}$ que 
determina o quão interessantes eles são para serem explorados pelo rato e um valor $A_{i}$ que determina quão amedrontadores eles são para o organismo. O animal explora o labirinto pulando de quadrado em quadrado e a cada passo é calculado o valor da diferença $M_{i}-A_{i}$ para cada um dos quadrados adjacentes e o quadrado com o maior valor dessa diferença terá maior probabilidade de ser escolhido para uma visita no passo seguinte. A diferença $M_{i}-A_{i}$ representa a competição entre duas das três forças inicialmente descritas, as que incitam a explorar ou a evitar certos locais. A terceira força incrementa o valor de $M_{i}-A_{i}$ de apenas um dos possíveis locais adjacentes, escolhido aleatoriamente. A escolha da posição a ser incrementada dá preferência às posições que ficam na direção da "cabeça" do organismo. Dessa maneira, foi possível pelo modelo simular mudanças repentinas de direção, porém condicionando-as a uma preferência pelos locais que ficam no campo visual do organismo.

O modelo computacional de Giddings (Giddings, 2002), por sua vez, está baseado na ideia de que o comportamento exploratório do rato no LCE pode ser simulado equiparando-se a motivação exploratória com uma força parecida com a de inércia. Para esse modelo, a direção na qual o organismo se move num dado momento condiciona a direção para onde ele se moverá no passo seguinte.

Seguindo um procedimento similar ao que Salum et al. (Salum, Roque e Morato, 2000) utilizaram para discretizar o labirinto, Giddings (Giddings, 2002) dividiu o piso do labirinto em pequenos quadrados (três por cada braço), cada um deles indicando o local que o organismo pode visitar. O deslocamento do organismo através do labirinto depende de um número aleatório que é comparado com os valores de probabilidade de ser visitado que cada um dos locais possui. As probabilidades atribuídas a cada local do labirinto foram estimadas a partir de dados experimentais de ratos controle submetidos ao LCE. Embora essas probabilidades tenham sido ajustadas para reproduzir o comportamento de maior exploração dos braços fechados, esses valores mudam ao longo da sessão em função da direção de movimento do organismo e de sua localização dentro do labirinto.

Finalmente, o modelo de Miranda et al. (Miranda et al., 2009) está baseado no conceito de que o comportamento do rato no LCE está sob o controle de quatro tipos de estímulos externos: a intensidade da iluminação, a presença de paredes ao redor dos braços, a altura das paredes e o número de vezes que um dado local foi visitado. Esse modelo foi desenvolvido usando uma rede neural artificial (RNA) treinada pelo algoritmo de retro-propagação de erros (“backpropagation”) (Haykin, 2008). A estrutura do labirinto foi também dividida em pequenos quadrados seguindo um esquema similar ao de Giddings (Giddings, 2002) com três quadrados por cada braço. A cada quadrado foi atribuído um valor específico de cada um dos quatro tipos 
de variáveis e esses valores foram fornecidas à RNA na forma de densidades. O organismo se desloca pelo labirinto pulando de quadrado em quadrado seguindo o mesmo esquema dos outros modelos. A saída da rede neural determina a direção do deslocamento do animal. O treinamento da rede foi feito baseado em experimentos com animais controle em condições normais, isto é, sem nenhum tratamento que modifique seu comportamento.

Um aspecto comum a todos os modelos é o tratamento do problema do comportamento exploratório do rato como um processo de tomada de decisão: em cada momento, as posições possíveis para onde o rato pode se deslocar têm probabilidades ou pesos específicos e o movimento é decidido em função dessas probabilidades. Cada modelo, porém, usou procedimentos distintos para determinar essas probabilidades, as quais foram ajustadas por comparação com medidas experimentais. Nenhum modelo, no entanto, usou diretamente as probabilidades de transição de um quadrado para outro obtidas a partir das medidas das frequências relativas de transição entre quadrados observáveis experimentalmente. Uma das características desta tese é justamente utilizar essas probabilidades de transição e foi com base nelas que se construiu o modelo markoviano do Capítulo 3.

Um outro aspecto comum aos três modelos é o fato de que eles simulam somente a condição de um rato controle. Nenhum deles simula uma condição de rato ou camundongo submetido aos efeitos de drogas. Além disso, apenas o modelo de Salum et al. (Salum, Roque e Morato, 2000) simula configurações espaciais diferentes do LCE (com todos os braços abertos e com todos os braços fechados). Esta é talvez uma das principais deficiências dos três modelos, pois o LCE é amplamente utilizado para testar os efeitos das drogas e é de se esperar que modelos computacionais dediquem especial atenção a este aspecto.

Com relação aos tipos de comportamento simulados, só o modelo de Salum et al. (Salum, Roque e Morato, 2000) considerou comportamentos diferentes do de locomoção simples, como os de exploração das paredes dos braços fechados e das bordas dos braços abertos. Os outros dois modelos somente simularam o deslocamento do animal. Nos três casos, porém, os deslocamentos de um quadrado a outro se davam a intervalos de tempo constantes, ou seja, cada novo passo era dado em um intervalo de tempo fixo após o anterior. Devido a isso, em todos os modelos, o tempo de permanência em um dado braço fica determinado pelo número de deslocamentos no interior do braço.

Em termos gerais pode-se dizer que, embora os três diferentes modelos para o comportamento exploratório do rato no LCE tenham oferecido importantes contribuições para o entendimento desse comportamento, ainda há alguns aspectos relevantes não modelados que justificam o desenvolvimento de novos modelos. Dentre esses aspectos, de especial importân- 
cia é a necessidade de simular os efeitos de diferentes tipos de fármacos. Uma das propostas deste trabalho é construir um modelo capaz de simular pelo menos os efeitos de drogas ansiolíticas e ansiogênicas. Esse novo modelo também tem que levar em consideração as medidas mais detalhadas sobre o comportamento exploratório do rato descritas nos Capítulos 2 e 3, além das medidas tradicionais de número de entradas e tempo de permanência. O modelo em questão é objeto do Capítulo 4.

Uma das características do novo modelo e que o diferencia dos anteriores é a de que o tempo de permanência em um dado quadrado não é o mesmo para todos os quadrados. É justamente esta característica que permite ao modelo discriminar os efeitos de drogas ansiolíticas dos de drogas ansiogênicas. As drogas ansiogênicas podem aumentar a locomoção, medida pelo número de entradas e deslocamentos, mas mantêm a preferência espacial pelos braços fechados medida pelo tempo de permanência. Como no novo modelo as entradas e os deslocamentos em um dado braço não determinam o tempo de permanência neste braço, é possível diferenciar entre os dois tipos de drogas.

Embora seja diferente dos três anteriores, o novo modelo, no entanto, leva em conta algumas ideias trabalhadas por eles. Por exemplo, o novo modelo considera uma competição entre forças como no modelo de Salum et al. (Salum, Roque e Morato, 2000). Da mesma forma, ele também adotou a ideia de simular o deslocamento como uma sequência de tomadas de decisões e incluiu um elemento que representa a cabeça do animal para dar preferência à direção em que o animal se desloca num dado momento. Assim como o modelo de Miranda et al. (Miranda et al., 2009), o novo modelo é também um modelo conexionista. Porém, ao invés de perceptrons, o novo modelo se baseia no modelo de dipolo chaveado ("gated dipole") de Grossberg (Grossberg, 1980) para simular o conflito entre diferentes decisões e é descrito em termos de equações diferenciais dependentes do tempo.

Outra característica do novo modelo é a de que ele possui uma estrutura flexível que permite usá-lo para simular o comportamento do animal em um labirinto com uma configuração espacial diferente da do LCE, no caso a Arena.

A Arena é também um labirinto usado no estudo de ansiedade pela observação dos comportamentos espontâneos dos animais quando expostos a uma situação nova (Rodgers e Johnson, 1998; Belzung e Griebel, 2001). Nesse labirinto, os animais são expostos a um ambiente desconhecido, similar ao que acontece no LCE, constituído por um espaço de forma circular ou quadrada com mais ou menos $1 \mathrm{~m}$ de diâmetro no caso do círculo ou $50 \mathrm{~cm}$ de largura no caso do quadrado. Essa área circular ou quadrada é rodeada por paredes de 45 cm circundando todo o perímetro (Prut e Belzung, 2003). O animal inicia a sessão no centro 
do labirinto e, assim como no caso do LCE, permite-se que ele o explore livremente durante 5 min. O comportamento padrão do animal na Arena é explorar e permanecer por mais tempo perto das paredes (Lister, 1990).

A Arena e o LCE têm várias características em comum: ambos avaliam o comportamento exploratório como uma medida de ansiedade, centrando sua atenção no padrão de deslocamento e no tempo que o animal permanece num dado local. Adicionalmente, ambos dispensam a necessidade de treinamento ou de privação alimentar. Teoricamente, os dois labirintos compartilham as mesmas hipóteses acerca das variáveis que controlam o comportamento dos animais submetidos a eles. Em ambos os casos se considera que o comportamento é controlado por motivações opostas, uma que os insta a explorar um novo ambiente e outra que os insta a evitar locais amedrontadores: um conflito definido como de aproximação-evitação (Montgomery, 1955; Lister, 1990). Controlado por esse conflito, o comportamento dos animais é o de permanecer por mais tempo nas áreas consideradas seguras (braços fechados no LCE e cantos na Arena) explorando pouco e permanecendo por pouco tempo nas outras áreas dos labirintos.

Apesar de serem modelos similares, porém, ainda não há consenso sobre qual dos dois deve ser usado num dado estudo ou se é necessário que ambos sejam usados (Ramos, 2008; Ramos et al., 2008). Adicionalmente, diferentes estudos em que se compara o LCE com a Arena usando análise fatorial apresentam resultados incongruentes no que diz respeito aos comportamentos que denotam ansiedade. Em um deles (Ramos et al., 1998) não foram encontradas correlações entre os fatores que agruparam os comportamentos relacionados com ansiedade nos dois labirintos. Porém, num outro estudo (Carola et al., 2002) foi encontrada uma correlação negativa entre esses fatores. Isto pode sugerir que os padrões de comportamentos relacionados com ansiedade são específicos de cada labirinto. Já com relação aos fatores que agrupam os comportamentos relacionados à atividade exploratória, em ambos os estudos foi encontrada uma correlação entre esses fatores e também entre fatores que agrupam comportamentos não relacionados com ansiedade (Ramos et al., 1998; Carola et al., 2002).

Essas incongruências são evidências de diferenças nos comportamentos dos animais dentro de cada labirinto e é de se esperar que um modelo computacional que se aplique a ambos seja capaz de capturá-las. Desta maneira, o modelo estaria identificando mecanismos similares e diferentes em cada situação.

Finalmente, é importante mencionar que, embora o novo modelo se aplique aos dois tipos de labirinto, ele não propõe a redução do comportamento observado na Arena ao compor- 
tamento observado no LCE. Cada um dos dois testes comportamentais fornece informações relevantes sobre o comportamento do rato quando explora um novo ambiente.

A intenção desta tese é dar os primeiros passos no desenvolvimento de um modelo computacional que simule a exploração que um animal faz de um determinado local sem que haja uma tarefa a realizar ou uma recompensa a obter. O modelo, portanto, é diferente de outros modelos computacionais propostos para simular atividade exploratória, como o de Schmajuk (Voicu e Schmajuk, 2000) por exemplo. 


\section{Caracterização do comportamento do rato no $L C E$ usando grafos direcionados}

Como foi mencionado na introdução, parte do trabalho de construir um modelo computacional é desenvolver métodos que permitam uma melhor avaliação do comportamento do animal no interior do labirinto. Aportando novas medições centradas em aspectos pouco avaliados previamente, o interesse é caracterizar o comportamento exploratório considerando todos os locais do labirinto e não somente o que acontece ao redor do centro. Para isto propomos a utilização de grafos direcionados (Diestel, 2005) para representar o comportamento do rato no LCE. Um grafo direcionado é um conjunto de nós interligados por setas, sendo que as transições entre os nós somente são possíveis nas direções definidas pelas setas. Nessa representação, os nós do grafo são pequenos quadrados nos quais foi dividido o piso do labirinto e o deslocamento do rato seria registrado como se ele ao se deslocar transitasse de um nó para outro. A equivalência é possível dado que o animal explora o labirinto se mexendo sequencialmente de um quadrado para outro sempre com uma direção bem definida. Na figura 2.1 é representada a maneira como o LCE foi dividido e como é registrado o comportamento do animal em termo de transições.

Sob esta representação a ideia é registrar as frequências e o tempo de cada uma das transições arranjando-as num ranking ordenado do maior valor para o menor valor e gerar um gráfico cartesiano de duas dimensões com a frequência ou o tempo no eixo y e a posição no ranking no eixo $x$. Este tipo de aproximação oferece detalhes mais finos sobre o comportamento exploratório do que apenas a determinação do número total de entradas em um braço ou do tempo total gasto no braço. Ela revela por que locais no interior do labirinto o animal transita mais ou permanece mais tempo, ao mesmo tempo que discrimina a direção do deslocamento em cada ponto. Adicionalmente, o fato de se poder representar as frequências em um gráfico cartesiano permite que se ajuste uma função decrescente aos pontos cujos parâmetros caracterizem o estado do animal, por exemplo, o efeito de drogas. 
(a)

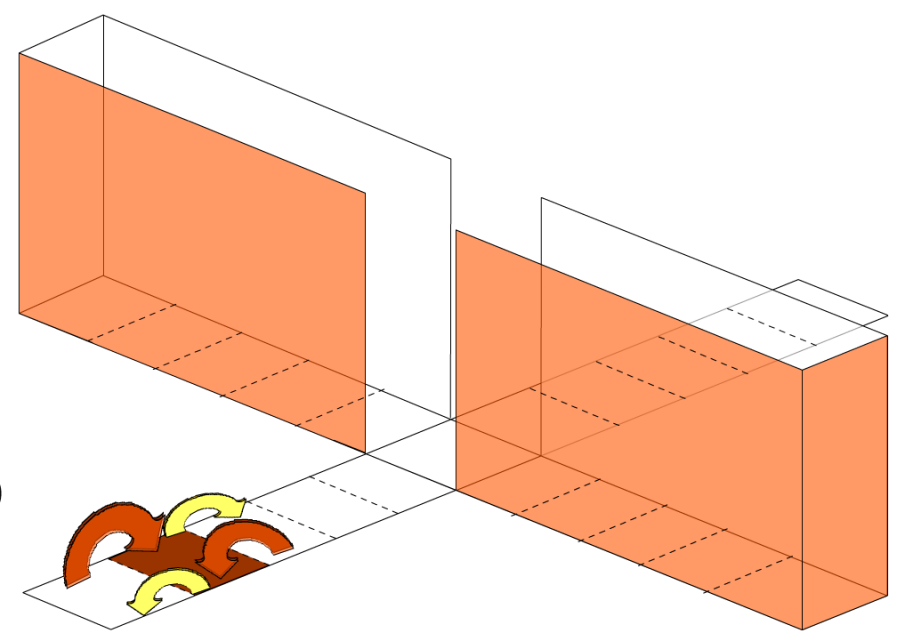

(b)

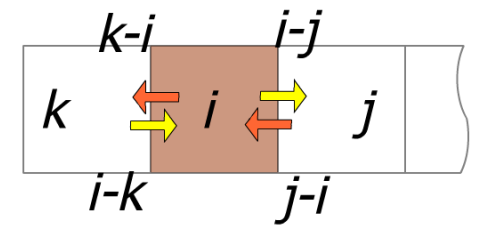

Figura 2.1: (a) Esquema do LCE apresentando as divisões do piso em quadrados e as possíveis transições que o animal pode realizar ao se movimentar de um quadrado para outro. (b) Detalhe de três quadrados vizinhos (nós) mostrando as possíveis transições que do nó $i$ se pode fazer para os nós vizinhos $j$ e $k$.

A seguir, será descrito o estudo realizado com animais reais com o objetivo de definir novas medidas de caracterização do comportamento do rato no LCE, o qual foi publicado no Journal of Neuroscience Methods em 2009 (Tejada et al., 2009).

\subsection{Método}

Foram feitos registros de 130 ratos submetidos ao LCE em diferentes tratamentos farmacológicos que consistiam na administração de drogas ansiogênicas (pentilenotetrazol, PTZ, 10, 20 e 30 mg/kg; semicarbazida, SCZ, 20 mg/kg) e ansiolíticas (midazolam, MDZ, 1 mg/kg; clordiazepóxido, CDP, $5 \mathrm{mg} / \mathrm{kg}$ ). Todos os experimentos foram realizados no Laboratório de Comportamento Exploratório da Universidade de São Paulo em Ribeirão Preto. Do total de 130 ratos, 29 foram tratados e registrados especialmente para o presente trabalho e os dados restantes gentilmente cedidos por Andrea Milena Garcia Becerra, Ana Cristina Madalena Costa, Javier Leonardo Rico Rodríguez e Túlio Marcos Nuñes, pesquisadores do laboratório. Uma relação do número de animais e da dosagem das drogas é apresentada na tabela 2.1. 
Tabela 2.1: Número de ratos, tratamento farmacológico e dosagem para cada um dos grupos experimentais.

\begin{tabular}{l|l|l|l}
\hline Condição Experimental & Droga & Dosagem & Número de ratos \\
\hline \hline \multirow{3}{*}{ Ansiogênico } & & $10 \mathrm{mg} / \mathrm{kg}$ & 12 \\
& PTZ & $20 \mathrm{mg} / \mathrm{kg}$ & 12 \\
& & $30 \mathrm{mg} / \mathrm{kg}$ & 10 \\
& Semicarbazida & $20 \mathrm{mg} / \mathrm{kg}$ & 11 \\
\hline \multirow{2}{*}{ Ansiolítico } & CDP & $5 \mathrm{mg} / \mathrm{kg}$ & 22 \\
& MDZ & $1 \mathrm{mg} / \mathrm{kg}$ & 17 \\
\hline Grupo controle & \multicolumn{2}{|c}{} & 46 \\
\hline
\end{tabular}

Para a análise dos registros foi utilizado um software desenvolvido no mesmo Laboratório, que divide o labirinto em pequenos quadrados (como na figura 2.2 (a)) permitindo o registro manual de cada uma das transições. Definimos uma transição quando o animal se desloca de um quadrado para outro colocando suas quatro patas no novo quadrado. Não foram consideradas transições nas quais o animal só estirou o corpo colocando suas duas patas dianteiras num quadrado enquanto mantinha as traseiras fixas em outro quadrado.

Como estratégia para reduzir a variabilidade dos dados e simplificar o processo de ajuste do gráfico de frequência/tempo versus ranking, foi utilizada uma representação reduzida do LCE. Nesta, um dos braços abertos era rebatido sobre seu outro par e um dos braços fechados era rebatido sobre o outro. Por causa disso, o grafo em forma de cruz do LCE pode ser reduzido a um grafo linear com só um braço aberto e só um braço fechado (ver figura 2.2). Esta redução é possível devido à simetria do labirinto, à uniformidade nas condições físicas do laboratório (luminosidade, temperatura, etc), e ao fato de que para a maioria dos estudos com o LCE é irrelevante em qual dos braços abertos ou fechados acontece um dado comportamento, pois geralmente resume-se o que acontece nos dois braços abertos ou fechados numa só medida (Pellow e File, 1986; Carobrez e Bertoglio, 2005). Finalmente, não se tem evidência de que o rato prefira virar numa determinada direção (Schwarting e Borta, 2005) e consequentemente apresente uma diferença na frequência de comportamentos entre os dois braços abertos ou os dois fechados, sendo a ausência dessa preferência um motivo a mais para justificar a utilização do modelo reduzido para estudar o comportamento do rato no LCE.

Para cada rato foi registrado o número de vezes que ele cruzou uma determinada transição e o tempo que ele levou, discriminando em cada quadrado o local de onde o animal vinha. Por exemplo, no quadrado $i$ da figura 2.1 (b) são contadas como diferentes as vezes em que o animal transitou de $j$ para $i$ e as vezes em que ele transitou de $k$ para $i$. Essas frequências e o tempo que o animal levou para realizá-las foram arranjadas da maior para a menor atribuindo-se o ranking $R=1$ ao maior valor, o ranking $R=2$ ao seguinte valor e assim 


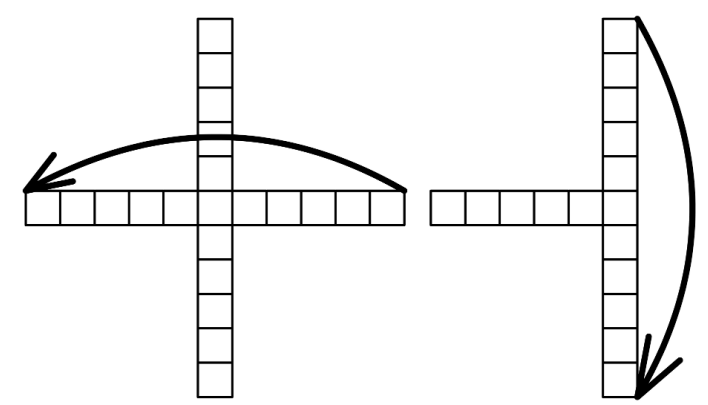

(a)

(b)
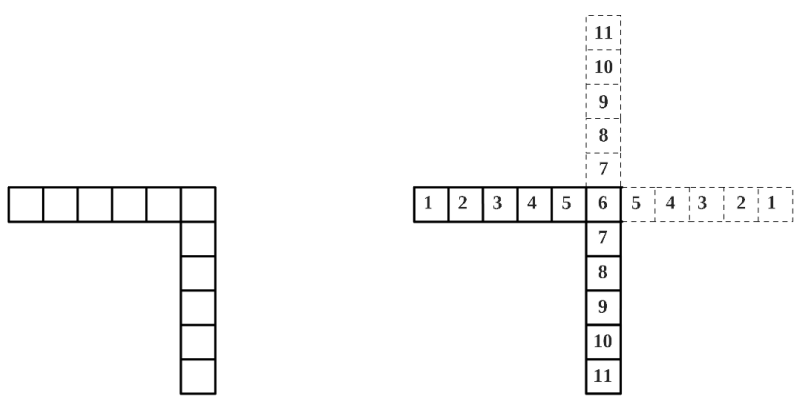

(c)

(d)

Figura 2.2: A figura mostra como foi construida a representação reduzida do LCE: (a) o braço aberto direito foi rebatido ao redor do quadrado central sobre o braço aberto esquerdo, (b) o braço fechado superior foi rebatido ao redor do quadrado central sobre o braço fechado inferior. (c) A representação reduzida do LCE que consiste em um único braço aberto e um único braço fechado. (d) Para a contagem das transições considerou-se que os quadrados nos braços abertos rebatidos tiveram o mesmo número atribuído aos correspondentes quadrados nos braços não rebatidos.

sucessivamente. Com essa informação foram construídos gráficos de frequência contra ranking e de tempo contra ranking que foram ajustados usando cada uma das funções apresentadas na tabela 2.2. O objetivo por trás do ajuste dos gráficos era achar uma função cujos parâmetros fossem sensíveis aos efeitos dos fármacos sobre o comportamento exploratório. Além das funções, para cada gráfico foi também calculada a sua entropia de Shannon (Shannon, 1948) (calculada pela fórmula descrita na última linha da tabela 2.2). Isto foi feito na tentativa de explorar outras possibilidades de índices que resumam o comportamento do animal.

Baseado nos resultados dos ajustes, escolheu-se a função lei de potência para representar as curvas ${ }^{1}$, pois ela ofereceu um ótimo ajuste e é relativamente simples do ponto de vista matemático (possui poucos parâmetros). É importante mencionar aqui que não é necessário para este estudo utilizar a função que forneça o melhor ajuste, pois não se está querendo encontrar "o modelo" que explique os dados, mas apenas uma função matemática simples que reproduza bem seu comportamento. O ajuste entre os dados e as funções foi avaliado por

\footnotetext{
${ }^{1}$ No apêndice A é apresentado o código para calcular o expoente da lei de potência no Matlab (C)1994-2010 The MathWorks, Inc.) a partir dos registros das transições ou dos tempos de permanência.
} 
Tabela 2.2: Funções utilizadas no processo de procura do melhor ajuste.

\begin{tabular}{ll}
\hline Nome da função & Equação \\
\hline \hline Linear & $a x+b$ \\
\hline Polinômio de grau n & $a x^{n}+b x^{n-1}+\ldots+c x^{3}+d x^{2}+e x+f$ \\
\hline Exponencial & $a e^{-\frac{x}{x_{0}}}$ \\
\hline Razão entre polinômios (de graus n e n+1) & $\frac{a_{1} x^{n}+a_{2} x^{n-1}+a_{3} x^{n-2}+\ldots+a_{n} x+a_{n+1}}{b_{1} x^{n}+b_{2} x^{n-1}+b_{3} x^{n-2}+\ldots+b_{n} x+b_{n+1}}$ \\
\hline Lei de potência & $\frac{f=c R^{-k}}{b+a}$ \\
\hline Logística & $\frac{a}{b+c e^{d x}}$ \\
\hline Variante 1 da lei de potência & $\frac{a}{b+x^{c}}$ \\
\hline Variante 2 da lei de potência (Lei de Zipf- & $\frac{a}{(b+x)^{c}}$ \\
Mandelbrot) & $N$ \\
\hline Entropia & $\sum_{k=1}^{N} f_{k} \log _{2} f_{k}$ \\
\hline
\end{tabular}

meio dos próprios gráficos de dispersão (inspeção visual), pelo coeficiente de correlação de Pearson $(r)$ entre o logaritmo de $f$ e $R$, e por um índice utilizado para avaliar a bondade do ajuste, o Qui-quadrado reduzido (Bevington e Robinson, 1992).

Para avaliar a capacidade do expoente $k$ da função lei de potência como indicador de uma condição farmacológica foi utilizado o coeficiente de correlação de postos de Spearman entre o tipo de condição farmacológica e dosagem e o expoente $k$. A associação entre 0 expoente $k$ e as medidas tradicionais foi analisada utilizando-se o teste $t$ de Student para comparação de médias. Finalmente, para avaliar a qualidade dos dados utilizados no estudo da caracterização foi novamente utilizado o teste $t$ de Student para comparação de médias e a análise de variância (ANOVA) de uma via e o teste Post-hoc de Duncan nos casos em que isso foi apropriado.

\subsection{Resultados}

Os gráficos de frequência e de tempo de permanência contra ranking obtidos seguindo o procedimento anteriormente descrito são apresentados na figura 2.3. Cada uma das barras representa uma transição que o rato pode fazer no interior do labirinto rebatido e o número embaixo delas representa o local dentro do labirinto no qual a transição ocorreu. Com exceção dos quadrados dos extremos, cada um dos 11 locais em que foi dividido o labirinto rebatido é representado por duas barras. Uma para quando o animal entrou nesse local andando na direção dos braços fechados (identificado pela seta apontando para esquerda) e outra para quando o animal entrou nessa posição andando na direção dos braços abertos (identificado 
pela seta apontando para direita).

Os gráficos de frequência contra ranking (ver figura 2.3) apresentam um padrão diferente para cada condição farmacológica considerada, o que sugere uma relação entre a forma do gráfico, a distribuição das barras e o tipo de fármaco e a dosagem. Por exemplo, os gráficos dos grupos tratados com drogas ansiogênicas (PTZ e SDZ) apresentam uma ordem clara na qual os locais nos braços fechados são sempre os mais transitados, indicado pelas barras pretas que representam locais nos braços fechados à esquerda dos gráficos, e barras cinza que representam locais nos braços abertos no outro extremo. Já nos grupos tratados com drogas ansiolíticas (MDZ e CDP) essa ordem desaparece, podendo-se encontrar barras cinza intercaladas com barras pretas. Outra característica interessante está na altura das barras, que vão diminuindo com a intensidade da droga ansiogênica, como se pode observar no caso do PTZ 30 mg que é o único grupo no qual há um quadrado que não foi visitado.

Por outro lado, os gráficos de tempo de permanência contra ranking (ver figura 2.3) não apresentam um padrão claro como o obtido com os gráficos das freqüências, o que não permite estabelecer uma possível relação entre o padrões dos gráficos e os tratamentos farmacológicos. Os padrões apresentados não permitem discriminar um tratamento farmacológico, nem pela altura das barras nem pela posição delas, já que as barras cinzas e pretas se intercalam em todas as condições.

Quando se comparam as alturas médias das barras dos tratamentos ansiogênicos com as dos tratamentos ansiolíticos, encontra-se que a altura média das barras de frequência para os grupos tratados com ansiolíticos $(7,087 \pm 0,275)$ é maior que a altura média das barras de frequência dos grupos tratados com ansiogênicos $(3,837 \pm 0,252)$, obtendo-se uma diferença significativa ao se usar um teste $t$ de Student $\left(t_{[81]}=-8,723, P<0,001\right)$. Ao repetir o mesmo teste comparando-se as alturas médias das barras do tempo de permanência, a altura média das barras dos grupos tratados com ansiolíticos $(2,9483 \pm 0,2720)$ é praticamente igual à altura média das barras dos grupos tratados com ansiogênicos $(2,9198 \pm 0,2560)$, obtendo-se um valor de $t$ de Student muito próximo de zero $\left(t_{[81]}=-0,62973, P>0,05\right)$.

O padrão que aparece ao se comparar as alturas médias das barras de frequência entre os grupos apresenta uma relação entre a atividade e o tipo de fármaco. Desta maneira, fármacos ansiolíticos aumentam o número de vezes que o rato se desloca de uma posição para outra. Por sua vez, fármacos ansiogênicos diminuem a atividade de rato, e consequentemente a altura das barras. Essa diminuição está relacionada também com a dosagem, como foi encontrado quando foram comparadas as alturas médias das barras de frequência de transição entre os três grupos tratados com PTZ com diferentes dosagens. A altura média das barras para o 
Braços Fechados Centro Braços Abertos

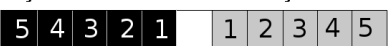
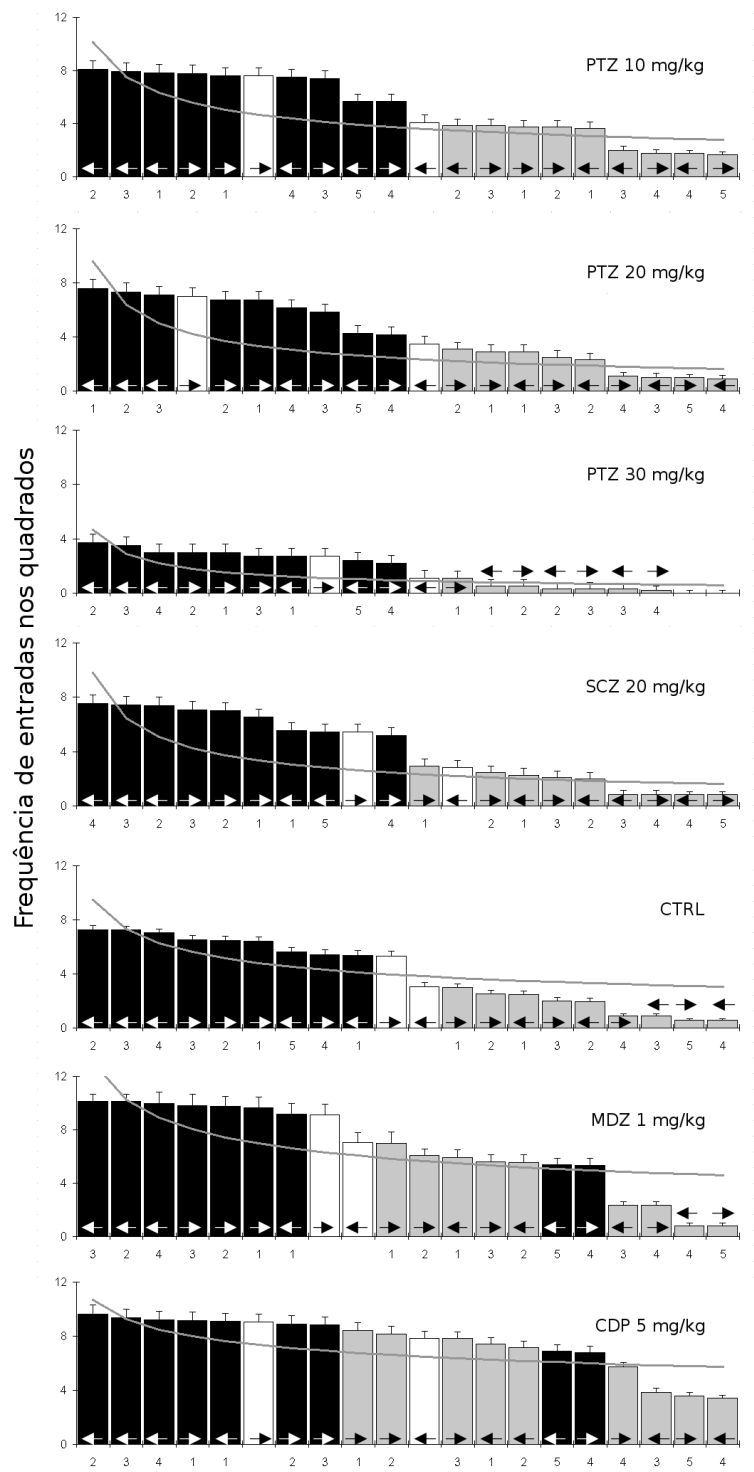

Posição dos quadrados

(a)
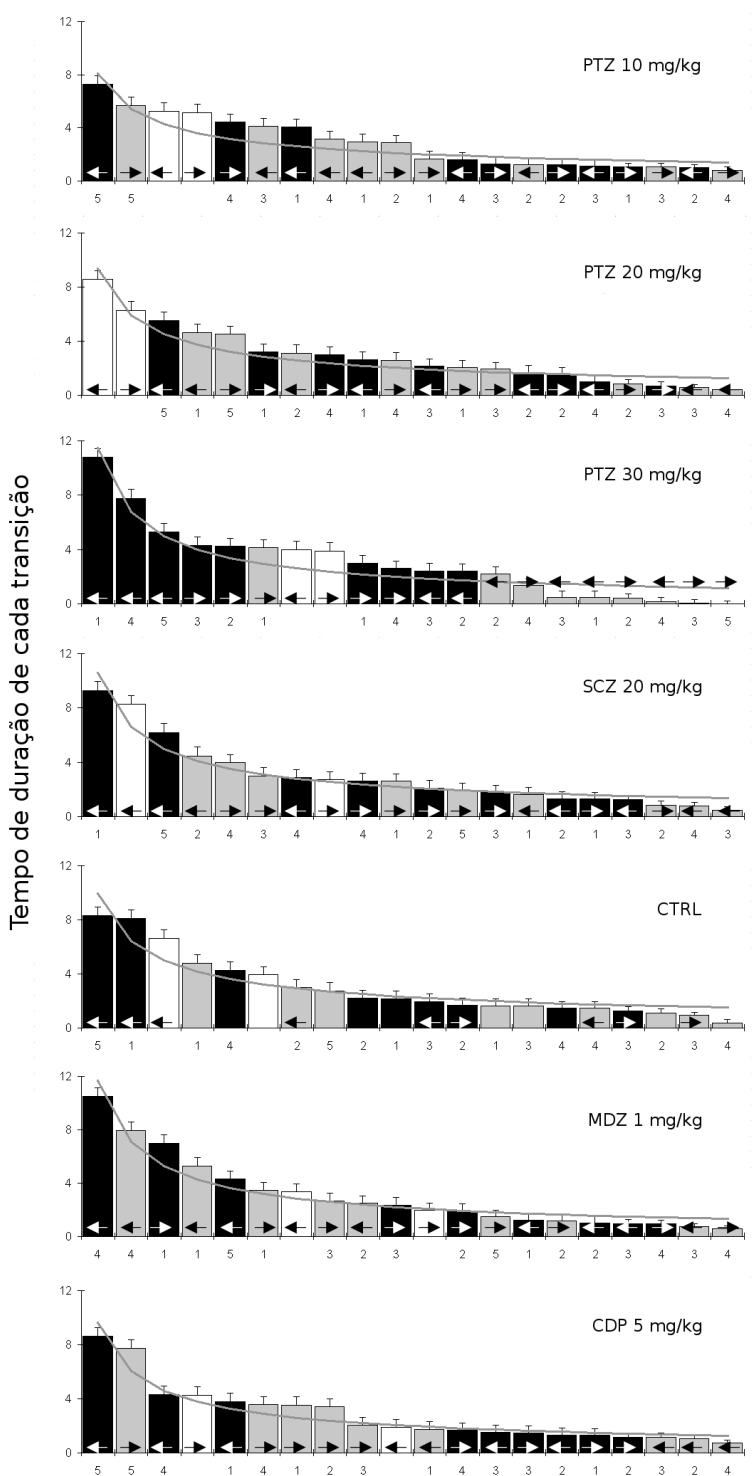

Posição dos quadrados

(b)

Figura 2.3: Frequências (a) e tempo de permanência (b) de cada uma das possíveis transições que o rato pode fazer no LCE rebatido, com as ordenadas organizadas da maior para a menor para cada uma das condições experimentais. As barras de erro indicam a média do erro padrão. Os números sob as barras pretas (braços fechados), cinzas (braços abertos) e brancas (centro) indicam a posição do quadrado no labirinto rebatido. As setas, que são duas por cada quadrado, indicam se o rato estava indo em direção aos braços fechados (seta apontando para a esquerda) ou em direção aos braços abertos (seta apontando para direita) quando fez a transição. Por último, a linha contínua representa a curva obtida com o melhor ajuste da função de lei de potência. 
grupo com dosagem $10 \mathrm{mg} / \mathrm{kg}$ foi de 5.071 土0,397; para o grupo com dosagem de $20 \mathrm{mg} / \mathrm{kg}$ foi de $4.192 \pm$ 0,383; e finalmente para o grupo com dosagem de $30 \mathrm{mg} / \mathrm{kg}$ a média foi de 1,645 \pm 0,336. Esses resultados sugerem que a maior intensidade da dosagem está associada a uma menor altura média das barras e, consequentemente, a uma menor atividade exploratória. Um teste ANOVA apresenta diferenças devidas à dosagem $\left(F_{[2 ; 31]}=20,846 ; P<0,001\right)$ e o teste post-hoc de Duncan indica que a dosagem de $30 \mathrm{mg} / \mathrm{kg}$ provoca uma diminuição de atividade significativamente maior que as outras dosagens. Novamente, os mesmos teste feitos para os gráficos de tempo de permanência não oferecem nenhum padrão. As alturas das barras de tempo de permanência para os três grupos de PTZ foram muito similares (com 2,7187 \pm 0,6333 para $10 \mathrm{mg} / \mathrm{kg}, 2,7134 \pm 0,6858$ para $20 \mathrm{mg} / \mathrm{kg}$ e 2,8571 $\pm 0,8743$ para $30 \mathrm{mg} / \mathrm{kg}$ ) sem apresentar diferenças significativas $\left(F_{[2 ; 31]}=0,03 ; P>0,05\right)$.

Das diferentes curvas utilizadas para testar o ajuste dos gráficos de frequência e de tempo de permanência contra ranking, somente a lei de potência no caso dos gráficos de frequência apresentou um padrão para os valores de um dos seus parâmetros que satisfaz o objetivo proposto: o de caracterizar os diferentes tratamentos farmacológicos. O parâmetro $k$ da lei de potência encontrado ao se ajustar os gráficos de frequência é diferente para cada um dos grupos farmacológicos. Além disso, ele mantém uma ordem (ver figura 2.4) o que sugere que pode ser utilizado para caracterizar cada condição farmacológica.

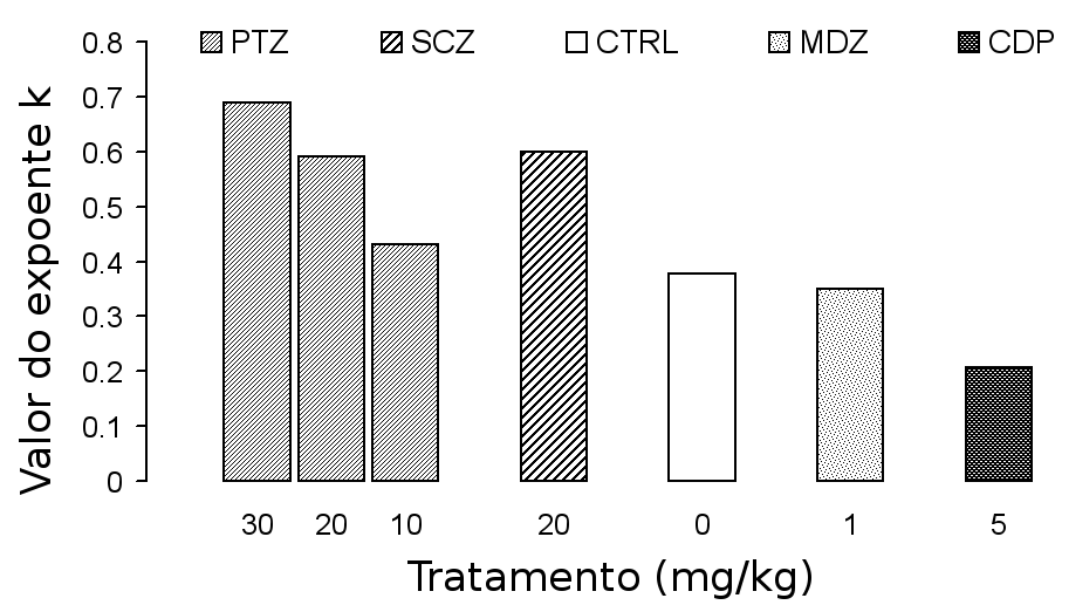

Figura 2.4: Gráfico de cada um dos valores de $k$ para cada grupo farmacológico e sua respectiva dosagem. No eixo $x$ a condição farmacológica varia da droga ansiogênica com a mais alta dosagem para a droga ansiogênica com a mais baixa, passando pelo grupo controle e terminando com os dois grupos de drogas ansiolíticas. A altura de cada barra indica o valor de $k$.

Baseado nessa relação entre o expoente da lei de potência e os gráficos de frequência de transições, foram feitos testes para avaliar a bondade do ajuste da lei de potência aos dados, resultando que a correlação entre os logaritmos de $f$ e $R$ foi alta e significativa para 
todas as condições farmacológicas, e o qui-quadrado reduzido apresentou valores próximos a 1 para todos os grupos. Esses dois resultados podem ser vistos na tabela 2.3, onde também são apresentados os valores obtidos para os parâmetros da lei de potência ajustada a cada grupo farmacológico.

Tabela 2.3: Valores de qui-quadrado reduzido, coeficiente de correlação (entre $\ln f$ e $\ln R$ ) e os parâmetros da lei de potência com os quais se ajustou cada grupo experimental. Os asteriscos representam valores significativos.

\begin{tabular}{lllll}
\hline Condição Experimental & $X_{\text {red }}^{2}$ & $r$ & $c$ & $k$ \\
\hline PTZ $10 \mathrm{mg} / \mathrm{kg}$ & 0,923 & $0,827^{*}$ & 10,1 & 0,43 \\
PTZ $20 \mathrm{mg} / \mathrm{kg}$ & 0,969 & $0,847^{*}$ & 9,58 & 0,59 \\
PTZ $30 \mathrm{mg} / \mathrm{kg}$ & 0,938 & $0,810^{*}$ & 4,68 & 0,69 \\
SCZ $20 \mathrm{mg} / \mathrm{kg}$ & 0,979 & $0,814^{*}$ & 9,81 & 0,6 \\
CTRL & 0,973 & $0,785^{*}$ & 9,47 & 0,38 \\
MDZ $1 \mathrm{mg} / \mathrm{kg}$ & 0,999 & $0,682^{*}$ & 13,06 & 0,35 \\
CDP $5 \mathrm{mg} / \mathrm{kg}$ & 0,990 & $0,838^{*}$ & 10,68 & 0,21 \\
\hline
\end{tabular}

A hipotética relação entre os valores do expoente $k$ da lei de potência e os efeitos farmacológicos sobre as frequências de transições foi testada através de um índice de correlação de postos de Spearman entre o tipo de droga e dosagem e o $k$. Na figura 2.4 pode-se observar que existe um decaimento monotônico de $k$ com a redução da dosagem da droga ansiogênica, e a tendência se mantém através do grupo controle e posteriormente nos grupos com fármacos ansiolíticos. O índice de correlação de postos de Spearman calculado é alto $(0,98)$ e significativo, o que apoia a ideia de que o valor do expoente $k$ pode ser utilizado como um índice de caracterização do comportamento do rato no LCE.

Neste ponto, o passo a seguir era verificar a relação entre o expoente $k$ da lei de potência e as medidas tradicionais. Para isso foram calculados o número de entradas e o tempo de permanência de cada rato em cada condição farmacológica. Com essa informação, foi feita uma verificação sobre se os dados calculados para os animais estavam de acordo com os relatos na literatura. Para tal, foram comparadas a porcentagem de tempo gasto nos braços abertos e a porcentagem de entradas neles. Na figura 2.5 são apresentados estes resultados. Um teste ANOVA mostrou efeitos significativos devidos aos tratamentos farmacológicos tanto na porcentagem de entradas nos braços abertos $\left(F_{[6 ; 123]}=10,186 ; P<0,001\right)$ quanto na porcentagem de tempo gasto $\left(F_{[6 ; 123]}=43,312 ; P<0,001\right)$. O teste post-hoc de Duncan destacou que, em comparação com o grupo controle, os tratamentos com PTZ $10 \mathrm{mg} / \mathrm{kg}$, MDZ e CDP aumentaram o tempo gasto nos braços abertos, enquanto o tratamento com PTZ $30 \mathrm{mg} / \mathrm{kg}$ reduziu este tempo. Da mesma maneira, os grupos com MDZ e CDP, quando comparados com o grupo controle, incrementam o número de entradas nos braços abertos 
enquanto que o PTZ $30 \mathrm{mg} / \mathrm{kg}$ reduz estas entradas. Estes resultados demonstram que os dados utilizados efetivamente acompanham os resultados esperados sob os diferentes tratamentos farmacológicos.

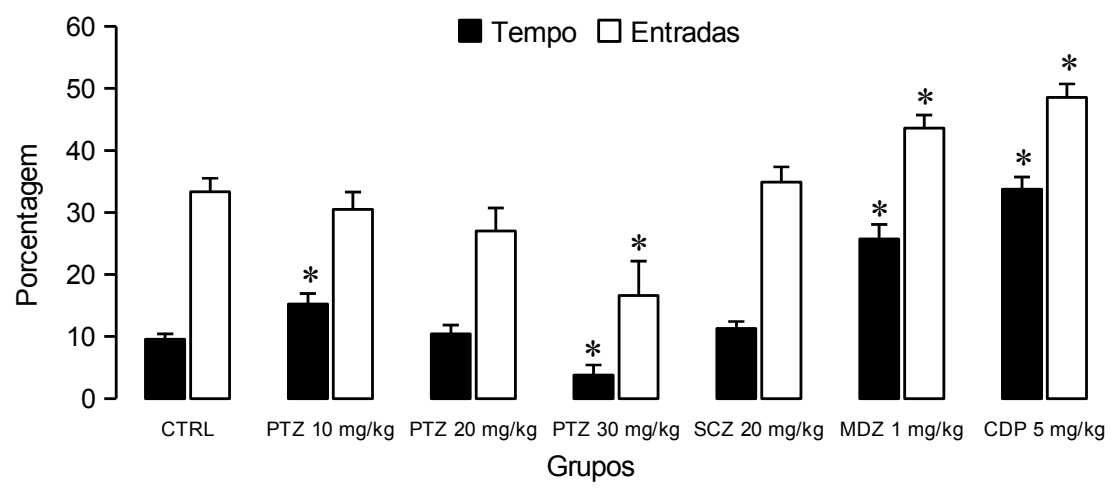

Figura 2.5: Porcentagem de entradas e tempo de permanência nos braços abertos. As barras indicam a porcentagem (calculadas respectivamente a partir do total de entradas em ambos os tipos de braços e do total de tempo gasto em toda a sessão). As barras de erro representam o erro padrão e os asteriscos diferenças significativas quando comparados com o grupo controle (Duncan, $\mathrm{P}<0,05$ ).

Uma vez verificado que os dados experimentais utilizados apresentam resultados dentro do esperado, realizou-se a avaliação da associação entre o expoente $k$ e as medidas que tradicionalmente são utilizadas para avaliar o comportamento do rato no LCE: tempo de entrada e tempo de permanência. Para isto foram calculadas as medidas tradicionais e o expoente $k$ para cada animal e calculado o índice de correlação de Pearson entre cada uma das medidas comportamentais e o expoente $k$. Os coeficientes de correlação obtidos são todos significativos e sugerem uma possível relação entre o expoente $k$ e as medidas tradicionais (ver tabela 2.4)

Tabela 2.4: Coeficiente de correlação de Pearson entre o expoente $k$ da lei de potência e as medidas comportamentais. Os coeficientes foram calculados a partir da informação obtida para cada rato $(\mathrm{N}=130) . r$, coeficiente de correlação; $P$, $p$-value.

\begin{tabular}{llr}
\hline Medidas & $r$ & $P$ \\
\hline Entradas nos braços abertos & 0,725 & $<0,001$ \\
Entradas nos braços fechados & 0,534 & $<0,001$ \\
Entradas totais & 0,693 & $<0,001$ \\
Tempo gasto nos braços abertos (s) & 0,725 & $<0,001$ \\
Tempo gasto nos braços fechados (s) & 0,408 & $<0,001$ \\
Tempo gasto no quadrado central (s) & 0,219 & 0,013 \\
Distância percorrida nos braços abertos (m) & 0,760 & $<0,001$ \\
Distância percorrida nos braços fechados (m) & 0,489 & $<0,001$ \\
Distância total percorrida (m) & 0,702 & $<0,001$ \\
\hline
\end{tabular}




\subsection{Discussão}

Para diferentes fins, como, por exemplo, o desenvolvimento de um modelo computacional, as medidas que tradicionalmente são utilizadas (tempo gasto e número de entradas) oferecerem uma descrição pouco detalhada do comportamento. Embora sejam medidas amplamente utilizadas e validadas como bons discriminadores dos efeitos dos fármacos, (Carobrez e Bertoglio, 2005; Walf e Frye, 2007) elas oferecem poucos detalhes sobre o que acontece ao interior dos braços, detalhes estes que podem ter relação com os efeitos de alguns fármacos. Por exemplo, sob um determinado fármaco o rato ao entrar num braço pode ficar simplesmente parado ou pelo contrário incrementar sua exploração do mesmo; mudanças desse tipo que não são registradas pelas medidas tradicionais.

Devido a estas limitações, propõe-se nesta tese uma nova maneira de caracterizar o comportamento exploratório do rato no LCE. Para isso foram consideradas as transições direcionadas entre os quadrados nos quais o LCE foi dividido. A ideia por trás disso, que efetivamente consiste em aumentar o número de áreas do LCE levadas em conta (em vez de apenas três áreas, os braços abertos, os fechados e o centro, tem-se agora os diversos quadrados dentro dos braços) é obter mais detalhes sobre a atividade exploratória do rato para se dispor de mais informação na tentativa de descobrir algum padrão que possa ser descrito por uma função. Neste sentido, a informação foi arranjada seguindo o esquema de ranking do maior para o menor para se usar funções monotônicas decrescentes, como a lei de potência com expoente negativo por exemplo. Procurou-se por parâmetros dessas funções que pudessem ser sensíveis às mudanças no comportamento sob efeito de fármacos. As freqüências também foram usadas para se calcular a entropia de Shannon para cada série de dados.

Dessa exploração conseguiu-se identificar um padrão destacável a partir das frequências de transições, permitindo uma visualização mais detalhada da atividade direcionada do rato em cada quadrado do labirinto. A informação foi arranjada em gráficos de frequência de transições contra ranking e foi obtido um índice numérico que resume em um único valor o padrão de exploração.

Os gráficos de frequência contra ranking permitem uma representação do comportamento exploratório do animal em todas as áreas do labirinto. Neles pode-se ver que o animal frequenta mais assiduamente os locais dentro dos braços fechados, porém mudando sua preferência em função do tipo de fármaco, da mesma maneira que a altura das barras muda em função não só do tipo de fármaco mas também da dosagem do mesmo, como foi observado quando comparados os gráficos obtidos para os três grupos com diferentes dosagens 
de PTZ. Nesses grupos, observou-se um decaimento gradual da atividade exploratória que acompanha o aumento da dosagem de acordo com o que é reportado na literatura (Pellow e File, 1986). Da mesma maneira, os gráficos capturam também os efeitos dos fármacos ansiolíticos que aumentam a atividade exploratória ao mesmo tempo que mudam o padrão de exploração (Dawson e Tricklebank, 1995), pois as barras dos grupos tratados com MDZ e CDP apresentaram uma altura maior e uma ordem distinta na sua distribuição.

As características encontradas nos gráficos de frequência de transições contra ranking adquirem valor especial quando se verifica que elas estão em concordância com o que se usa tradicionalmente para caracterizar o comportamento exploratório do rato no LCE (para uma revisão ver: Carobrez e Bertoglio, 2005; Rodgers et al., 1997; ver também Kliethermes, Finn e Crabbe, 2003).

Segundo os resultados obtidos com o estudo descrito neste capítulo, o expoente $k$ da lei de potência pode ser utilizado para descrever o comportamento exploratório do rato no LCE sob a ação de fármacos. Quando o animal está sob os efeitos de drogas ansiogênicas ele realiza mais transições nos braços fechados provocando valores altos do índice $k$; pelo contrário, quando está sob os efeitos de drogas ansiolíticas a sua exploração é mais ou menos uniforme em todas as regiões do labirinto e, consequentemente, ocorrem valores baixos do indice $k$.

Adicionalmente, o fato de se obter uma correlação monotônica significativa entre os valores do índice $k$ e as medidas de tempo de permanência, entradas e deslocamento calculadas tanto para braços abertos como fechados, e no caso do tempo também para o centro, apoia a proposta de que o expoente $k$ possa ser usado como um índice de comportamento exploratório capaz de resumir num número a relação entre exploração e ansiedade. Este índice será utilizado nos demais capítulos desta tese como um índice de comportamento exploratório para avaliar as simulações computacionais feitas. 


\section{Caracterização do comportamento do rato no LCE com cadeias de Markov}

A segunda etapa no processo de caracterização e modelagem do comportamento do rato no LCE consistiu em estudar a maneira como o rato toma as decisões. Este interesse surgiu a partir da análise dos três modelos anteriores (Salum, Roque e Morato, 2000; Giddings, 2002; Miranda et al., 2009 ), nos quais o deslocamento do animal era simulado como um processo de tomada de decisões, atribuindo a cada um dos locais ao redor do animal um valor de probabilidade de ser visitado no próximo passo. Este esquema se assemelha ao de um modelo de cadeia de Markov, no qual o estado de um sistema de estados discretos no passo seguinte é decidido em função das probabilidades dos estados nos quais ele pode estar nesse passo seguinte. Desta maneira, considera-se que a sequência de movimentos que o rato faz no interior do labirinto pode ser descrita por uma cadeia de Markov com os estados possíveis sendo os quadrados nos quais o labirinto é dividido e o passo seguinte sendo uma das posições ao redor do rato a cada instante.

As cadeias de Markov, no entanto, foram usadas apenas em parte do trabalho de modelagem descrito neste capítulo. Como as cadeias de Markov apresentam limitação na quantidade de informação do passado a ser usada, neste trabalho também se modelou o comportamento do rato usando modelos de ordem superior (Kemeny e Snell, 1976), os quais levam em consideração um determinado número de ações passadas na tomada de decisões. O uso de tais modelos permite estimar quanta informação é necessária para encontrar as probabilidades de transição de um estado para outro e se sob efeitos de algum tipo de tratamento farmacológico essa quantidade de informação muda.

\subsection{Método}

Uma cadeia de Markov simples será considerada como um processo aleatório $\left(X_{n}\right)_{n \in \mathbb{N}}$ homogêneo no tempo que assume valores em um espaço de estados finitos $S$. Esse processo 
obedece à seguinte propriedade:

$$
\mathbb{P}\left(X_{n+1}=l \mid X_{0}=k_{0}, X_{1}=k_{1}, \ldots, X_{n}=k_{n}\right)=\mathbb{P}\left(X_{n+1}=l \mid X_{n}=k_{n}\right) .
$$

Vamos denotar por $p_{i, j}$ a probabilidade de transição do estado $i$ para o estado $j$, ou seja,

$$
p_{i, j}=\mathbb{P}\left(X_{n+1}=j \mid X_{n}=i\right)
$$

e por $\mathbb{P}^{1}$, a matriz de transições de uma cadeia. Por exemplo, seja uma cadeia de Markov com três estados: 1, 2 e 3, para a qual se conhecem as probabilidades de transição. No caso, em que o organismo esteja no estado 1, a probabilidade de ele transitar para o estado 2 é igual a 0,7; a de ele transitar para o estado 3 é igual a 0,2; e a probabilidade de ele se manter no estado 1 é de 0,1. Da mesma maneira, as probabilidades de transição dos estados 2 e 3 para cada um dos três estados possuem valores que podem ser resumidos em uma tabela (ver figura 3.1 (a)). Nessa tabela, a soma das probabilidades em cada linha é igual a 1. Esse tipo de tabela é chamada de matriz estocástica ${ }^{2} \mathbb{P}$ e costuma ser representada como na figura 3.1 (b).

\begin{tabular}{l|c|c|c} 
& Estado 1 & Estado 2 & Estado 3 \\
\hline Estado 1 & 0,10 & 0,70 & 0,20 \\
\hline Estado 2 & 0,45 & 0,10 & 0,45 \\
\hline Estado 3 & 0,25 & 0,55 & 0,20
\end{tabular}

$$
\mathbb{P}=\left(\begin{array}{lll}
0,10 & 0,70 & 0,20 \\
0,45 & 0,10 & 0,45 \\
0,25 & 0,55 & 0,20
\end{array}\right)
$$

(b)

(a)

Figura 3.1: Valores de probabilidade de transitar para cada um dos possíveis estados da cadeia de Markov do exemplo dado no texto, representados numa tabela (a) e como uma matriz estocástica $\mathbb{P}(\mathrm{b})$.

Na modelagem do comportamento do rato no LCE usando-se cadeias de Markov, o objetivo foi calcular a matriz estocástica correspondente. Para tal se trabalhou com uma representação reduzida do labirinto como a que foi utilizada no primeiro estudo de caracterização (ver figura 2.2, na página 14). Considerou-se cada um dos locais do labirinto como um dos estados que constituem a cadeia de Markov. Portanto, o modelo possui 11 possíveis estados, os quais estão ligados com os estados adjacentes (ver figura 3.2). Neste esquema, considerou-se que o animal não permanece no estado em que se encontra no instante seguinte e, por isso, a figura 3.2 não tem setas que ligam um dado estado a ele mesmo.

\footnotetext{
${ }^{1}$ Para facilitar a notação, utilizaremos a letra $\mathrm{p}$ para denotar tanto probabilidade $(p)$ quanto as matrizes estocásticas $(\mathbb{P})$.

${ }^{2} \mathrm{~A}$ matriz estocástica é uma matriz cujos elementos são positivos e a soma dos elementos de cada linha é igual a 1.
} 
O ponto de partida é o estado 6, que representa o centro do labirinto e que no modelo rebatido reduzido possui somente dois estados ligados a ele, de maneira similar a qualquer outro estado do labirinto com exceção dos dois extremos. Quando o animal encontra-se neste estado, somente há duas possibilidades para se movimentar: transitar para a posição 5, que está nos braços abertos, ou transitar para a posição 7, que está nos braços fechados.

Desta forma, como todos os estados têm a característica de possuir somente dois estados vizinhos para onde transitar, a tomada de decisões que o organismo realiza dentro deste modelo pode ser simulada por um ensaio de Bernoulli onde $p_{i}$ é a probabilidade de 0 organismo, estando na posição $i$, transitar para a direita e $1-p_{i}$ é a probabilidade de ele transitar para a esquerda.

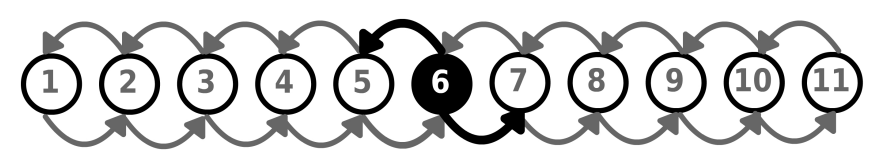

Figura 3.2: Modelo de Cadeia de Markov para a simulação do comportamento do rato no LCE. Cada número representa o local onde o organismo pode se encontrar num dado momento, as setas representam para onde ele pode-se deslocar.

Como ponto de partida tomou-se os registros dos 130 ratos descritos no capítulo anterior (ver tabela 2.1, na página 13) discriminando a sequência de passos que cada rato realizou no interior do labirinto. Cada um dos passos que cada rato realizou representa uma amostra de estados $x_{1}, x_{2}, \ldots, x_{n}$ sucessivos a partir dos quais calculou-se a matriz de probabilidades.

Essa matriz foi calculada para cada uma das condições farmacológicas utilizando-se os seguintes estimadores de máxima verossimilhança para $p_{i, j}, i=1,2, \ldots, 11, j \neq i=1,2, \ldots, 11$ :

$$
\hat{p}_{i, j}=\frac{n_{i, j}}{n_{i}}, i=1,2, \ldots, 11, j=1,2, \ldots, 11, \text { para } i \neq j
$$

onde $p_{i, j}$ é a probabilidade de o rato estando na posição $i$ transitar para $j, n_{i, j}$ é a frequência de vezes que o organismo transitou do estado $i$ ao $j$, e $n_{i}$ é definido como:

$$
n_{i}=\sum_{j=1}^{11} n_{i, j}, \text { para } j \neq i
$$

Por exemplo, para $i=2$ o número de vezes que um rato ocupa a posição 2 numa trajetória é dado por $n_{2}$. Neste caso, $n_{2}=n_{2,1}+n_{2,3}$, ou seja, soma-se a quantidade de vezes em que ele estando na posição 2 transitou para a 1 ou para a 3.

A matriz de probabilidades do modelo do LCE apresenta um padrão particular que denota 
a estrutura do labirinto com unicamente duas diagonais (ver figura 3.3). Isto se deve ao fato de que somente são considerados os deslocamentos dos animais, razão pela qual transições do tipo $i, i$, que representam que o rato permaneceu no mesmo local no instante seguinte, não foram consideradas.

$$
\mathbb{P}=\left(\begin{array}{ccccccccccc}
0 & p_{1,2} & 0 & 0 & 0 & 0 & 0 & 0 & 0 & 0 & 0 \\
p_{2,1} & 0 & p_{2,3} & 0 & 0 & 0 & 0 & 0 & 0 & 0 & 0 \\
0 & p_{3,2} & 0 & p_{3,4} & 0 & 0 & 0 & 0 & 0 & 0 & 0 \\
0 & 0 & p_{4,3} & 0 & p_{4,5} & 0 & 0 & 0 & 0 & 0 & 0 \\
0 & 0 & 0 & p_{5,4} & 0 & p_{5,6} & 0 & 0 & 0 & 0 & 0 \\
0 & 0 & 0 & 0 & p_{6,5} & 0 & p_{6,7} & 0 & 0 & 0 & 0 \\
0 & 0 & 0 & 0 & 0 & p_{7,6} & 0 & p_{7,8} & 0 & 0 & 0 \\
0 & 0 & 0 & 0 & 0 & 0 & p_{8,7} & 0 & p_{8,9} & 0 & 0 \\
0 & 0 & 0 & 0 & 0 & 0 & 0 & p_{9,8} & 0 & p_{9,10} & 0 \\
0 & 0 & 0 & 0 & 0 & 0 & 0 & 0 & p_{10,9} & 0 & p_{10,11} \\
0 & 0 & 0 & 0 & 0 & 0 & 0 & 0 & 0 & p_{11,10} & 0
\end{array}\right)
$$

Figura 3.3: Matriz estocástica que contém as probabilidades de que o animal transite de uma posição $i$ (filas) para outra posição $j$ (colunas) dentro do LCE rebatido.

Seguindo este procedimento foram calculadas 7 matrizes estocásticas, uma para cada grupo farmacológico, a partir das quais foram calculadas as probabilidades estacionárias que são vetores que devem satisfazer a condição $\pi=\pi \mathbb{P}$, onde

$$
\pi(j)=\lim _{n \rightarrow \infty} P_{i, j}^{n}
$$

$p_{i, j}^{n}$ é o elemento ij da matriz $\mathbb{P}^{n}$ e a matriz $\mathbb{P}^{n}$ é o resultado de se multiplicar $\mathbb{P}$, a matriz estocástica, $n$ vezes por ela mesma: $\mathbb{P}^{n}=\mathbb{P} \times \mathbb{P} \times \mathbb{P} \times \mathbb{P} \times \ldots \times \mathbb{P}$ (no apêndice $\mathrm{B}$ são apresentados ambos métodos para o cálculo do vetor de valores de $\pi$ ).

As distribuições de probabilidades estacionárias representam o estado de equilíbrio da cadeia, com o valor da fração limite de tempo que o organismo gasta em cada local. Pode-se descrever de uma outra maneira supondo que $N_{n}(i)$ é o número de vezes que o organismo visita $i$ num intervalo de tempo de 1 até $n$, ao fazer $n \rightarrow \infty, \frac{N_{n}(i)}{n} \rightarrow \pi$.

No contexto do LCE, esses valores de probabilidaes estacionárias serão interpretados como vetores que identificariam a probabilidade que cada local do labirinto tem de ser visitado pelo animal ao longo do tempo. Eles são calculados com o objetivo de compará-los sob diferentes condições farmacológicas.

A partir das matrizes estimadas foram simuladas trajetórias de ratos expostos a drogas ansiogênicas e ansiolíticas e de ratos do grupo controle. Essas sequências de estados foram analisadas agrupando os dados como se proviessem de ratos, calculando o número de transições da posição 6 para as posições 5 (o que seria similar às entradas nos braços abertos) e 7 
(que poderia se equiparar com as entradas nos braços fechados), e o número de deslocamentos que o rato fez entre as posições 1 a 5 (o que pode-se equiparar aos deslocamentos nos braços abertos) e das posições 7 à 11 (que seria equivalente aos deslocamentos nos braços fechados).

O ajuste dos dados com um modelo de cadeias de Markov foi avaliado atraves do teste de independência descrito por Guttorp (Guttorp, 1995), o qual se baseia na ideia de que a trajetória de passos que o rato fez no LCE pode ser considerada uma sequência de uma variável aleatória independentemente distribuída. Testando a hipótese nula de $H_{0}: p_{i, j}=\theta_{j}$ para cada $i \in S$ e cada $j \in S$ contra a hipótese alternativa de que os ratos se comportariam como numa cadeia de Markov. Sob a hipótese de independência pode-se calcular o logaritmo da razão de verossimilhança para testar $H_{0}$ seguindo:

$$
2 \sum_{i, j} n_{i, j} \log \frac{n_{i, j} / n_{i}}{n \cdot j / n}
$$

que tem uma distribuição assintótica $\chi^{2}$ com $S^{2}$ graus de liberdade, sendo $S$ o número de estados que para o caso é 11 . Onde $n_{i, j} / n_{i}$ é o estimador de máxima verossimilhança $\hat{p}_{i, j}$ apresentado na equação (3.2), e $n \cdot j$ e calculado seguindo:

$$
n_{\cdot j}=\sum_{i} n_{i, j}
$$

O modelo de cadeias de Markov pode não ser o melhor modelo para representar a trajetória de um rato, pois é razoável supor que o rato use mais informação do que simplesmente a do instante anterior para decidir seu comportamento a cada instante. Por esta razão, considerou-se nesta tese a utilização de cadeias de longo alcance. Uma cadeia de longo alcance é um processo estocástico de tempo discreto em que é necessário olhar para os $k$ estados anteriores para se determinar o próximo estado. Diz-se que $k$ é o alcance da cadeia. De maneira mais formal, pode-se definir uma cadeia de alcance $k$ como uma cadeia na qual a probabilidade de se estar no estado $n+1$ depende de quais estados o processo assumiu nos instantes $n, n-1, n-2, \ldots, n-k$. A probabilidade de o processo assumir o estado $i_{k+1}$ no instante $n+1$, dado que ele assumiu os estados $i_{k}, i_{k-1}, \ldots, i_{1}$ nos $k$ instantes anteriores é expressa por

$$
\mathbb{P}_{i_{1}, i_{2}, \ldots, i_{k+1}}=\mathbb{P}\left(X_{n+1}=i_{k+1} \mid X_{n}=i_{k}, \ldots, X_{1}=i_{1}\right)
$$

Por exemplo, numa cadeia de ordem 2 a probabilidade de que o animal se encontre na 
posição 1 dependerá de qual trajetória ele percorreu antes, se fez $3 \rightarrow 2$ ou $1 \rightarrow 2$, que são todas as possíveis trajetórias de ordem 2 que o animal pode realizar para chegar à posição 1.

A determinação da ordem da cadeia de ordem superior que melhor descreve os dados de deslocamento dos ratos no LCE foi feita usando-se três métodos: o critério de informação de Akaike (AIC) (Akaike, 1974), o critério de informação de Bayes (BIC) (Schwarz, 1978) e o método de estimação de máxima verossimilhança (Guttorp, 1995).

O primeiro dos testes utilizados para avaliar a ordem da cadeia é o AIC, que utiliza a uma variação da função de máxima verossimilhança definida como (Tong, 1975):

$$
M_{k}\left(X_{1}, \ldots, X_{n}\right)=\prod_{i_{1}, \ldots, i_{k+1}} \hat{p}_{i_{1}, i_{k+1}}^{n_{i_{1} \ldots i_{k+1}}}
$$

onde o estimador de máxima verossimilhança de $p_{i_{1}, i_{2}, \ldots, i_{k+1}}$ é

$$
\hat{p}_{i_{1}, \ldots, i_{k+1}}=\frac{n_{i_{1} \ldots i_{k+1}}}{n_{i_{1} \ldots i_{k}}}
$$

Com a função de máxima verossimilhança são calculados $M_{0}, M_{1}, M_{2}, \ldots, M_{k}$ sendo $k$ o valor do máximo alcance da cadeia que se quer testar. Em seguida calcula-se $\lambda_{k, i}$, que é a razão entre cada um dos valores estimados de $M_{i}$ para $i<k$ e $M_{k}\left(X_{1}, \ldots, X_{k}\right)$,

$$
\lambda_{i, k}=\frac{M_{i}\left(X_{1}, \ldots, X_{i}\right)}{M_{k}\left(X_{1}, \ldots, X_{k}\right)} \text { para } i=0,1,2, \ldots, k-1
$$

Posteriormente calcula-se o termo $\eta_{i, k}$, que é a base para o cálculo do $A / C$ e do $B / C$,

$$
\eta_{i, k}=-2 \ln \lambda_{i, k}
$$

Dessa maneira, a ordem da cadeia que é selecionada é aquela com o menor valor do estimador $A / C$, satisfazendo a condição

$$
A / C\left(\hat{i}_{A / C}\right)=\min _{0 \leqslant i<k} A / C(i)
$$

onde

$$
A / C(i)=\eta_{i, k}-2\left(s^{k}-s^{i}\right)(s-1)
$$

é a estatística de máxima verossimilhança modificada por uma função de penalização, que para o caso do $A / C$ é duas vezes o número de graus de liberdade. Nesta expressão s é o número de estados da cadeia, que para o caso do LCE reduzido é 11.

O cálculo do $B / C$ é muito similar ao do $A / C$, mudando somente na função de penalização 
que leva em conta a informação do tamanho da amostra.

$$
B / C\left(\hat{i}_{B / C}\right)=\min _{0 \leqslant i<k} B / C(i)
$$

e

$$
B / C(i)=\eta_{i, k}-2\left(s^{k}-s^{i}\right)(s-1) \ln n
$$

A função de máxima verossimilhança (3.7) utilizada para calcular o $A / C$ e o $B / C$ pode ser interpretada como uma generalização da equação (3.2) para cadeias de ordem $k$, na qual é calculada a razão entre a frequência de vezes que o rato fez uma sequência específica $n_{i_{1} \ldots i_{k+1}}$ e o número de vezes em que ele fez uma sequência de ordem inferior $n_{i_{1} \ldots i_{k}}$. Por exemplo, se o valor do alcance da cadeia for fixado em $k=3$, uma das possíveis sequências que o animal pode seguir é 1,2,3 e, como passo seguinte, ele pode transitar para as posições 4 ou 2. Desta maneira, para calcular os valores de $\hat{p}_{1,2,3, k+1}$ calcula-se

$$
\hat{p}_{1,2,3,4}=\frac{n_{1,2,3,4}}{n_{1,2,3}} \text { e } \hat{p}_{1,2,3,2}=\frac{n_{1,2,3,2}}{n_{1,2,3}} .
$$

Cada um dos valores do $\hat{p}$ deve ser elevado à frequência de vezes que uma dada sequência apareceu, de tal maneira que no cálculo do $M_{k}$ estejam tanto os valores de $\hat{p}$ quanto seu peso dado pelo número de vezes que essa trajetória apareceu. Por exemplo, supondo que o rato percorreu a seguinte trajetória em 30 passos

\section{6}

a partir da qual se quer achar o valor de $k=2$, seria preciso calcular os valores de $\hat{p}_{123}, \hat{p}_{212}, \hat{p}_{234}, \hat{p}_{321}, \hat{p}_{323}, \hat{p}_{345}, \hat{p}_{432}, \hat{p}_{456}, \hat{p}_{543}, \hat{p}_{545}, \hat{p}_{565}, \hat{p}_{567}, \hat{p}_{654}, \hat{p}_{676}$ e $\hat{p}_{765}$ para, posteriormente, multiplicar cada um deles seguindo o padrão da trajetória total

$$
M_{2}=\hat{p}_{123} \times \hat{p}_{234} \times \hat{p}_{345} \times \hat{p}_{456} \times \hat{p}_{565} \times \hat{p}_{654} \times \hat{p}_{543} \times \hat{p}_{432} \times \hat{p}_{323} \times \hat{p}_{234} \times \hat{p}_{345} \times \hat{p}_{456} \times
$$
$\hat{p}_{567} \times \hat{p}_{676} \times \hat{p}_{765} \times \hat{p}_{654} \times \hat{p}_{543} \times \hat{p}_{432} \times \hat{p}_{321} \times \hat{p}_{212} \times \hat{p}_{123} \times \hat{p}_{234} \times \hat{p}_{345} \times \hat{p}_{456}$,

o que se pode escrever como:

$M_{2}=\hat{p}_{123}^{2} \times \hat{p}_{212} \times \hat{p}_{234}^{3} \times \hat{p}_{321} \times \hat{p}_{323} \times \hat{p}_{345}^{3} \times \hat{p}_{432}^{2} \times \hat{p}_{456}^{3} \times \hat{p}_{543}^{2} \times \hat{p}_{545} \times \hat{p}_{565}^{2} \times \hat{p}_{567} \times$ $\hat{p}_{654}^{2} \times \hat{p}_{676} \times \hat{p}_{765}$

O estimador de máxima verossimilhança pode ser também utilizado de uma maneira diferente para avaliar cadeias de longo alcance, testando a hipótese estatística relacionada à ordem da cadeia. Desta maneira, fixando uma ordem máxima $m$ se pode testar as hipóteses: 
$H_{0}:$ a ordem da cadeia é $l,(l<m)$

$H_{1}:$ a ordem da cadeia é $m$.

A hipótese $H_{0}$ corresponde a $\mathbb{P}\left(X_{m+1}=x_{m+1} \mid X_{m}=x_{m}, \ldots, X_{1}=x_{1}\right)=\mathbb{P}\left(X_{m+1}=x_{m+1} \mid X_{m}=\right.$ $\left.x_{m}, \ldots, X_{m-l+1}=x_{m-l+1}\right)$ e o estimador de máxima verossimilhança sob $H_{0}$ é

$$
\hat{p}_{i_{1}, \ldots, i_{m}, i_{m+1}}=\frac{n_{i_{m-l+1}, \ldots i_{m+1}}}{n_{i_{m-l+1}, \ldots, i_{m}}}
$$

A estatística normalmente utilizada para testar a hipótese é

$$
\chi_{m, l}^{2}=\sum_{i_{1}, \ldots, i_{m+1}}=\frac{\left(n_{i_{1}, i_{2}, \ldots, i_{m+1}}-\hat{p}_{i_{1}, \ldots, i_{m}, i_{m+1}} n_{i_{1}, i_{2}, \ldots, i_{m}}\right)^{2}}{\hat{p}_{i_{1}, \ldots, i_{m}, i_{m+1}} n_{i_{1}, i_{2}, \ldots, i_{m}}}
$$

que tem distribuição assintótica $\chi^{2}$ com $s^{m}(s-1)-s^{l}(s-1)$ graus de liberdade, e onde $n_{i_{m-l+1}, \ldots, i_{m}}$ é o número de vezes que o processo assume o estado $i_{m-l+1}, \ldots, i_{m}$ na amostra. Desta maneira, a ordem estimada para a cadeia será o menor inteiro l que faz com que a hipótese $H_{0}$ seja aceita.

As estimações feitas pelo $A / C$, pelo $B / C$ e pelo estimador de máxima verossimilhança permitiram determinar qual é a ordem da cadeia que melhor se ajusta aos dados experimentais e, com isso, determinar quanta informação anterior o rato usa para tomar as decisões.

\subsection{Resultados}

As matrizes de transições calculadas para os diferentes grupos apresentaram padrões específicos que podem se relacionar com os efeitos das diferentes drogas. Por exemplo, no grupo controle as probabilidades de que o animal decida se deslocar em direção aos braços fechados vão aumentando à medida que ele vai se adentrando no braço aberto. Já no braço fechado as probabilidades de transitar em direção dos braços abertos ou em direção do fundo do braço são similares sem apresentar uma preferência específica por uma direção (ver figura 3.4). Esse padrão de comportamento se vê acentuado nos grupos tratados com drogas ansiogênicas, e como se pode ver na figura 3.5, no caso do grupo PTZ $30 \mathrm{mg} / \mathrm{kg}$ as probabilidades de se mover em direção aos braços abertos são menores que as encontradas para os ratos do grupo controle.

No entanto, as probabilidades calculadas para os grupos com drogas ansiolíticas apresentam um padrão diferente dos grupos com drogas ansiogênicos e controle. Os animais 


$$
P=\left(\begin{array}{ccccccccccc}
0 & 1,00 & 0 & 0 & 0 & 0 & 0 & 0 & 0 & 0 & 0 \\
0,35 & 0 & 0,65 & 0 & 0 & 0 & 0 & 0 & 0 & 0 & 0 \\
0 & 0,46 & 0 & 0,54 & 0 & 0 & 0 & 0 & 0 & 0 & 0 \\
0 & 0 & 0,44 & 0 & 0,56 & 0 & 0 & 0 & 0 & 0 & 0 \\
0 & 0 & 0 & 0,45 & 0 & 0,55 & 0 & 0 & 0 & 0 & 0 \\
0 & 0 & 0 & 0 & 0,34 & 0 & 0,66 & 0 & 0 & 0 & 0 \\
0 & 0 & 0 & 0 & 0 & 0,42 & 0 & 0,58 & 0 & 0 & 0 \\
0 & 0 & 0 & 0 & 0 & 0 & 0,47 & 0 & 0,53 & 0 & 0 \\
0 & 0 & 0 & 0 & 0 & 0 & 0 & 0,48 & 0 & 0,52 & 0 \\
0 & 0 & 0 & 0 & 0 & 0 & 0 & 0 & 0,54 & 0 & 0,46 \\
0 & 0 & 0 & 0 & 0 & 0 & 0 & 0 & 0 & 1,00 & 0
\end{array}\right)
$$

Figura 3.4: Matriz estocástica com as probabilidades de transição calculadas para o grupo controle.

$$
P=\left(\begin{array}{ccccccccccc}
0 & 1,00 & 0 & 0 & 0 & 0 & 0 & 0 & 0 & 0 & 0 \\
0 & 0 & 1,00 & 0 & 0 & 0 & 0 & 0 & 0 & 0 & 0 \\
0 & 0,50 & 0 & 0,50 & 0 & 0 & 0 & 0 & 0 & 0 & 0 \\
0 & 0 & 0,38 & 0 & 0,63 & 0 & 0 & 0 & 0 & 0 & 0 \\
0 & 0 & 0 & 0,31 & 0 & 0,69 & 0 & 0 & 0 & 0 & 0 \\
0 & 0 & 0 & 0 & 0,30 & 0 & 0,70 & 0 & 0 & 0 & 0 \\
0 & 0 & 0 & 0 & 0 & 0,43 & 0 & 0,57 & 0 & 0 & 0 \\
0 & 0 & 0 & 0 & 0 & 0 & 0,46 & 0 & 0,54 & 0 & 0 \\
0 & 0 & 0 & 0 & 0 & 0 & 0 & 0,50 & 0 & 0,50 & 0 \\
0 & 0 & 0 & 0 & 0 & 0 & 0 & 0 & 0,53 & 0 & 0,47 \\
0 & 0 & 0 & 0 & 0 & 0 & 0 & 0 & 0 & 1,00 & 0
\end{array}\right)
$$

Figura 3.5: Matriz estocástica com as probabilidades de transição calculadas para o grupo tratado com PTZ $30 \mathrm{mg} / \mathrm{kg}$.

dos grupos ansiolíticos não apresentam uma preferência marcada por uma ou outra direção, mesmo quando se deslocando pelos braços abertos como se pode observar na figura 3.6.

$$
P=\left(\begin{array}{ccccccccccc}
0 & 1,00 & 0 & 0 & 0 & 0 & 0 & 0 & 0 & 0 & 0 \\
0,46 & 0 & 0,54 & 0 & 0 & 0 & 0 & 0 & 0 & 0 & 0 \\
0 & 0,50 & 0 & 0,50 & 0 & 0 & 0 & 0 & 0 & 0 & 0 \\
0 & 0 & 0,51 & 0 & 0,49 & 0 & 0 & 0 & 0 & 0 & 0 \\
0 & 0 & 0 & 0,51 & 0 & 0,49 & 0 & 0 & 0 & 0 & 0 \\
0 & 0 & 0 & 0 & 0,48 & 0 & 0,52 & 0 & 0 & 0 & 0 \\
0 & 0 & 0 & 0 & 0 & 0,48 & 0 & 0,52 & 0 & 0 & 0 \\
0 & 0 & 0 & 0 & 0 & 0 & 0,49 & 0 & 0,51 & 0 & 0 \\
0 & 0 & 0 & 0 & 0 & 0 & 0 & 0,49 & 0 & 0,51 & 0 \\
0 & 0 & 0 & 0 & 0 & 0 & 0 & 0 & 0,56 & 0 & 0,44 \\
0 & 0 & 0 & 0 & 0 & 0 & 0 & 0 & 0 & 1,00 & 0
\end{array}\right)
$$

Figura 3.6: Matriz estocástica com as probabilidades de transição calculadas para o grupo tratado com CDP.

Os valores de $\pi$ achados para as diferentes posições do labirinto nas diferentes condições farmacológicas refletem os padrões apresentados nas matrizes de transições, mudando conforme o tratamento, permitindo que sejam utilizados para caracterizar a preferência do animal por alguns locais do labirinto, e os efeitos dos fármacos sobre esta.

Na tabela 3.1 são apresentados os valores de $\pi$ calculados para cada um dos locais 
do labirinto em cada um dos tratamentos farmacológicos, podendo-se observar os padrões de preferência específicos para cada droga. Esses padrões ficam claramente diferenciados quando comparados os valores do grupo controle com os da maior dosagem de PTZ e os valores do CDP (ver figura 3.7), os quais apresentam os padrões mais opostos. Os valores de $\pi$ para PTZ $30 \mathrm{mg} / \mathrm{kg}$ apresentam uma preferência marcada pelos locais nos braços fechados, que somados possuem uma probabilidade maior que $80 \%$ de serem escolhidos pelo rato para serem visitados, caindo só um pouco para o grupo controle $(75 \%)$, e ficando perto de $50 \%$ no grupo com CDP.

Tabela 3.1: Valores de $\pi$ calculados para cada um dos estados (posições dentro do LCE rebatido) e para cada um dos tratamentos farmacológicos.

\begin{tabular}{llllllllllll}
\hline & & \multicolumn{1}{c}{ Estados / Posições } \\
Tratamento & 1 & 2 & 3 & 4 & 5 & 6 & 7 & 8 & 9 & 10 & 11 \\
\hline PTZ $10 \mathrm{mg} / \mathrm{kg}$ & 0,02 & 0,05 & 0,06 & 0,06 & 0,06 & 0,10 & 0,15 & 0,15 & 0,15 & 0,13 & 0,06 \\
PTZ $20 \mathrm{mg} / \mathrm{kg}$ & 0,01 & 0,03 & 0,04 & 0,05 & 0,06 & 0,11 & 0,16 & 0,17 & 0,17 & 0,14 & 0,06 \\
PTZ $30 \mathrm{mg} / \mathrm{kg}$ & 0,00 & 0,01 & 0,02 & 0,02 & 0,04 & 0,09 & 0,15 & 0,19 & 0,20 & 0,19 & 0,09 \\
SCZ $20 \mathrm{mg} / \mathrm{kg}$ & 0,01 & 0,03 & 0,04 & 0,05 & 0,06 & 0,09 & 0,13 & 0,17 & 0,18 & 0,17 & 0,07 \\
CTRL & 0,01 & 0,03 & 0,04 & 0,04 & 0,05 & 0,09 & 0,13 & 0,17 & 0,19 & 0,18 & 0,08 \\
MDZ 1 mg/kg & 0,01 & 0,04 & 0,08 & 0,08 & 0,09 & 0,11 & 0,13 & 0,14 & 0,15 & 0,12 & 0,04 \\
CDP 5 mg/kg & 0,04 & 0,10 & 0,10 & 0,10 & 0,09 & 0,10 & 0,10 & 0,11 & 0,11 & 0,10 & 0,04 \\
\hline
\end{tabular}

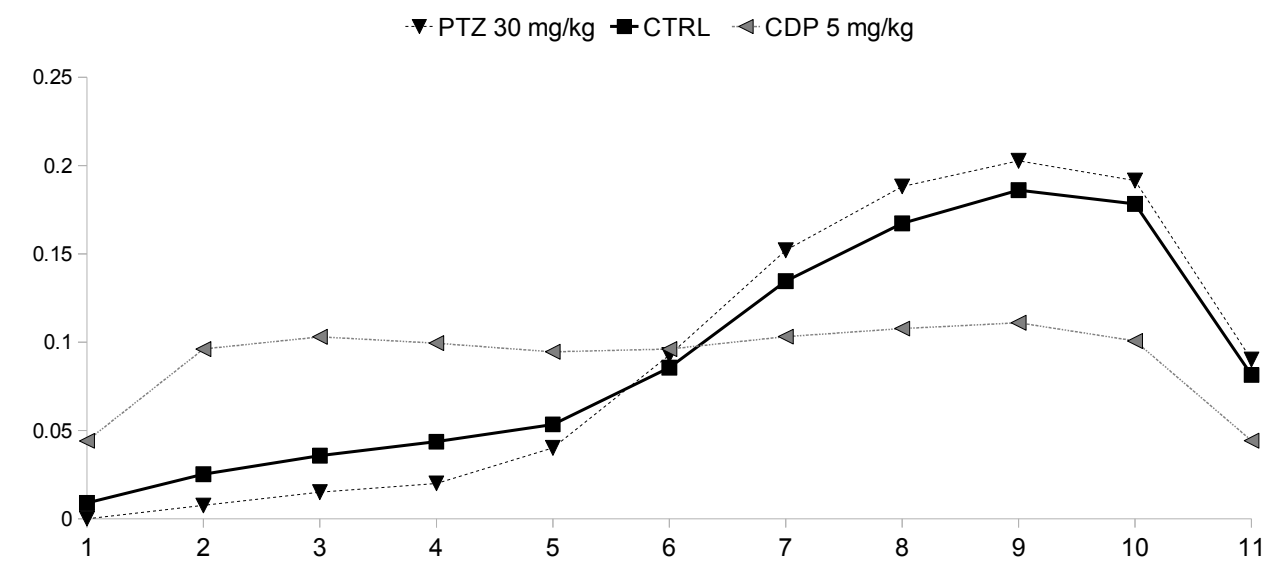

Figura 3.7: Valores de $\pi$ calculados para cada um dos estados (posições dentro do LCE rebatido) de três grupos farmacológicos, PTZ 30 mg/kg, Controle e CDP 5 mg/kg.

Os padrões de exploração gerados usando as matrizes de transição apresentaram um comportamento similar aos dos ratos. Isso tanto no número de entradas nos braços quanto no número de deslocamentos no interior deles. Nas figuras 3.8 e 3.9, são apresentadas a média de entradas e a média de deslocamentos obtidos ao se gerar 10 padrões de exploração com cada uma das matrizes de transição (barras brancas). Esse valores são similares aos dos respectivos grupos farmacológicos (barras escuras nas figuras 3.8 e 3.9) a partir dos 
quais foram geradas as matrizes, o que apóia a ideia de que as matrizes de transições são capazes de capturar informação detalhada do comportamento do rato sob diferentes condições farmacológicas.

Dados Experimentais $\square$ Dados Simulados

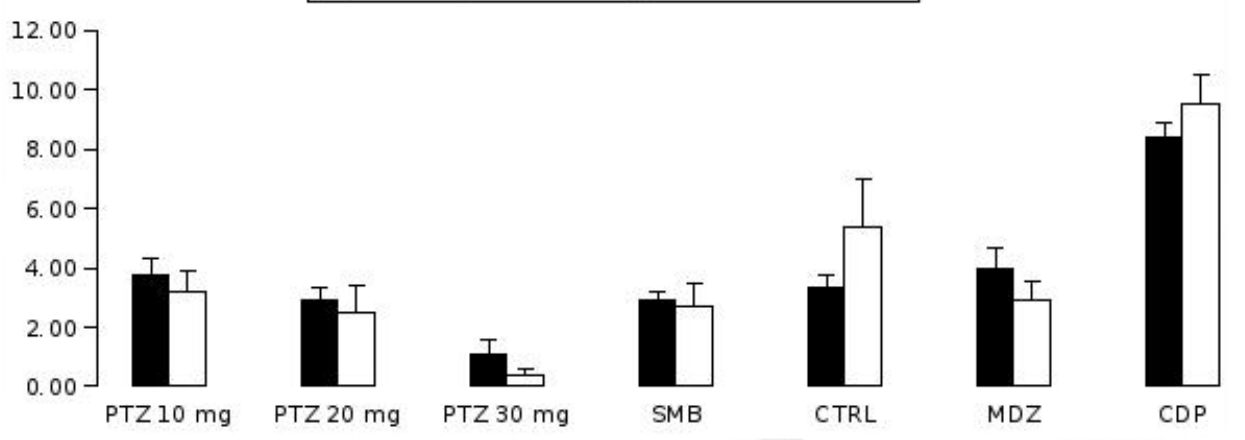

(a)

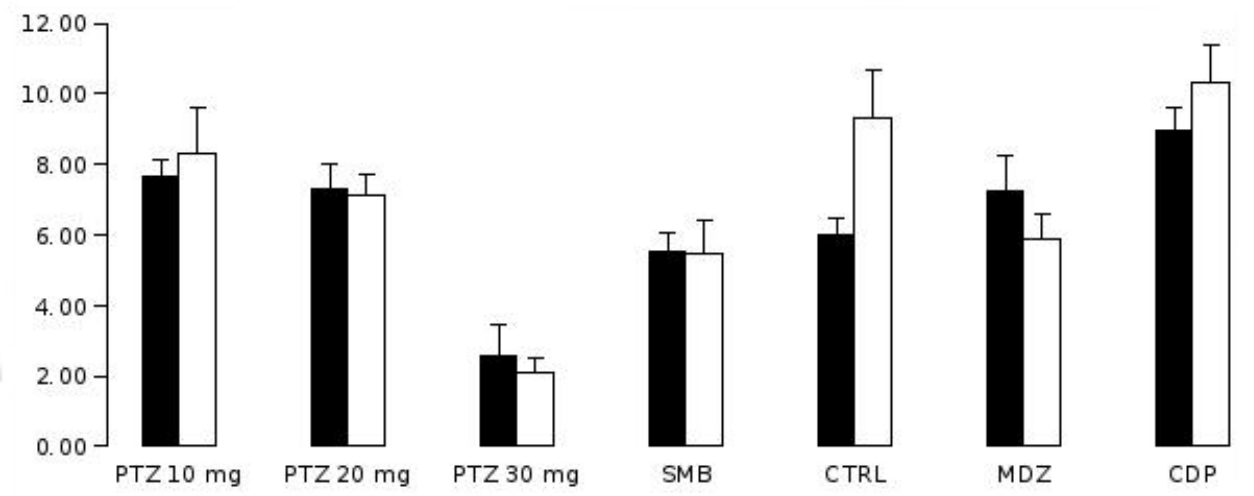

(b)

Figura 3.8: Média e erro padrão das entradas nos braços abertos (a) e fechados (b) para as sete condições farmacológicas diferentes calculados usando os dados experimentais e os simulados.

Na tabela 3.2 são apresentados os valores do logaritmo da razão de verossimilhança do teste de independência para todas as condições farmacológicas, esses valores permitem rejeitar a $H_{0}$ de independência, considerando que as diferentes trajetórias que os ratos fizeram sob as diferentes condições farmacológicas não podem ser consideradas independentes.

Tabela 3.2: Valores do logaritmo da razão de verossimilhança do teste de independência para todas as condições farmacológicas. Todos os valores são superiores ao valor de prova para uma distribuição $x^{2}$ com 11 graus de liberdade $\left(\chi_{[121 ; 0,95]}^{2}=147,67\right)$.

\begin{tabular}{ccccccc}
\hline \multicolumn{2}{c}{ Ansiolítico } & Controle & \multicolumn{4}{c}{ Ansiogênico } \\
\hline CPD & MDZ & & PTZ 10 mg/kg & PTZ 20 mg/kg & PTZ 30 mg/kg & SDZ \\
\hline 11995,76 & 446,72 & 7988,61 & 355,27 & 277,56 & 927,57 & 170,89 \\
\hline
\end{tabular}

Com relação a uma ordem superior à de uma cadeia de Markov, o cálculo dos três índices ( $A / C, B / C$ e estimador de máxima verossimilhança) ofereceu informação importante. Em 


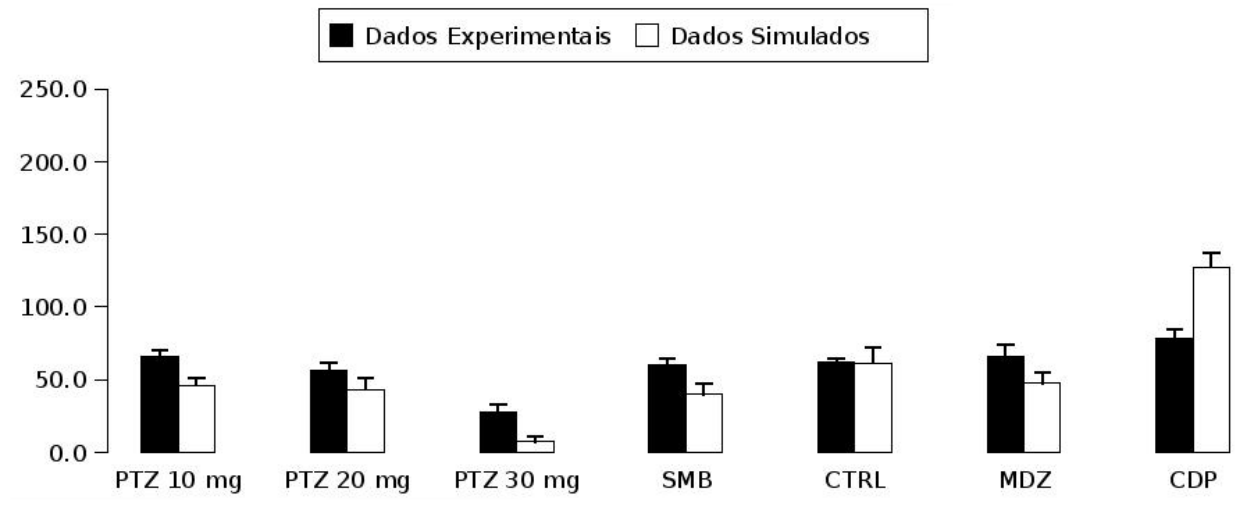

(a)
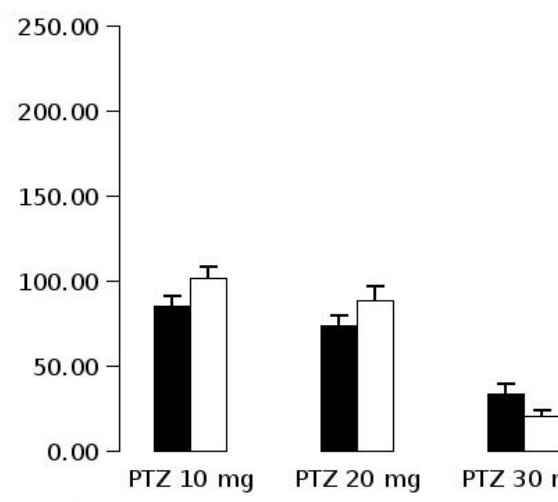

PTZ $30 \mathrm{mg}$
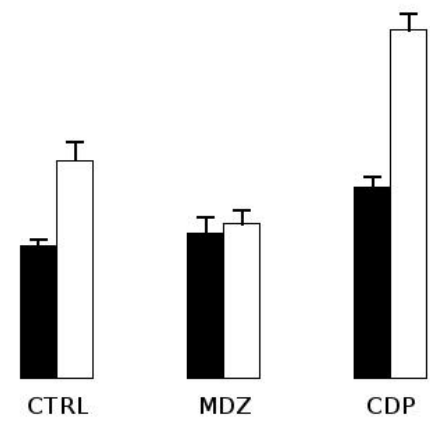

(b)

Figura 3.9: Média e erro padrão dos deslocamentos nos braços abertos (a) e fechados (b) para as sete condições farmacológicas diferentes calculados usando os dados experimentais e os simulados.

termos gerais, não se dispõe de informação suficiente para afirmar que a ordem da cadeia de Markov que pode representar o comportamento do rato deva ser superior a 1. Na tabela 3.3 são apresentados os valores dos índices $A / C$ e $B / C$ calculados para todos os grupos fixando $m=3$. Nessa tabela pode-se observar que em todas as condições farmacológicas os menores valores de $A / C$ correspondem a $k$ igual ou menor a 1 . Como é de se esperar, os menores índices para o $B / C$ correspondem a valores de $k$ inferiores aos encontrados com o $A / C$, no caso $k$ igual a 0 , dado que na estimação do $B / C$ o termo $\eta_{k, m}$ é punido por um termo maior que o utilizado no $A / C$. Adicionalmente são apresentados na tabela 3.4 os valores de $\eta_{k, m}$ utilizados para os cálculos do $A / C$ e o $B / C$.

Por último, a tabela 3.5 apresenta os valores do estimador de máxima verossimilhança calculados para comparar a hipótese de que a ordem máxima da cadeia é 3. Nela todos os valores calculados tanto para $l=1$ como $l=2$ fizeram com que a $H_{0}$ fosse aceita. Desta maneira, a ordem da cadeia seria 1, o que corresponde ao menor valor de $l$ que faça $H_{0}$ ser aceita. 
Tabela 3.3: Valores de $A / C$ e $B / C$ calculados, fixando $m=3$, a partir dos dados de cada uma das diferentes condições farmacológicas.

\begin{tabular}{|c|c|c|c|c|c|c|c|}
\hline \multicolumn{8}{|c|}{ AIC } \\
\hline & \multicolumn{2}{|c|}{ Ansiolítico } & \multirow[t]{2}{*}{ Controle } & \multicolumn{4}{|c|}{ Ansiogênico } \\
\hline & CPD & MDZ & & PTZ $10 \mathrm{mg} / \mathrm{kg}$ & PTZ $20 \mathrm{mg} / \mathrm{kg}$ & PTZ $30 \mathrm{mg} / \mathrm{kg}$ & SDZ \\
\hline$k=0$ & $-292099,54$ & $-292226,35$ & $-292398,95$ & $-292345,09$ & $-292441,31$ & $-292685,97$ & $-292464,96$ \\
\hline$k=1$ & $-292442,70$ & $-292471,26$ & $-292508,51$ & $-292493,80$ & $-292516,21$ & $-292570,48$ & $-292521,21$ \\
\hline$k=2$ & $-290393,95$ & $-290394,62$ & $-290393,58$ & $-290395,86$ & $-290391,77$ & $-290395,23$ & $-290393,67$ \\
\hline$k=3$ & $-266196,82$ & $-266196,97$ & $-266195,73$ & $-266197,26$ & $-266196,70$ & $-266197,87$ & $-266197,17$ \\
\hline \multicolumn{8}{|c|}{$\overline{\mathrm{BIC}}$} \\
\hline & \multicolumn{2}{|c|}{ Ansiolítico } & Controle & \multicolumn{4}{|c|}{ Ansiogênico } \\
\hline & CPD & MDZ & & PTZ $10 \mathrm{mg} / \mathrm{kg}$ & PTZ $20 \mathrm{mg} / \mathrm{kg}$ & PTZ $30 \mathrm{mg} / \mathrm{kg}$ & SDZ \\
\hline $\mathrm{k}=0$ & $-1482763,36$ & $-1431545,96$ & $-1326382,67$ & $-1359702,09$ & $-1294409,92$ & $-969599,93$ & $-1296665,18$ \\
\hline$k=1$ & $-1482293,22$ & $-1431012,64$ & $-1325785,97$ & $-1359121,73$ & $-1293800,41$ & $-969022,06$ & $-1296035,51$ \\
\hline$k=2$ & $-1471298,23$ & $-1420375,55$ & $-1315902,03$ & $-1349004,03$ & $-1284147,52$ & -961760,71 & $-1286362,75$ \\
\hline$k=3$ & $-1348692,41$ & $-1302012,82$ & $-1206245,15$ & $-1236588,08$ & $-1177139,48$ & $-881616,23$ & $-1179168,82$ \\
\hline
\end{tabular}

Tabela 3.4: Valores de $\eta_{k, m}$ calculados fixando $m=3$, a partir dos quais foram calculados os índices $A / C$ e $B / C$.

\begin{tabular}{rrrrrrrr}
\hline \multicolumn{3}{c}{ Ansiolítico } & Controle & \multicolumn{5}{c}{ Ansiogênico } \\
\hline & CPD & MDZ & & PTZ 10 mg/kg & PTZ 20 mg/kg & PTZ 30 mg/kg & SDZ \\
\hline $\mathrm{k}=0$ & 700,46 & 573,65 & 401,05 & 454,91 & 358,69 & 114,03 & 335,04 \\
$\mathrm{k}=1$ & 157,30 & 128,74 & 91,49 & 106,20 & 83,79 & 29,52 & 78,79 \\
$\mathrm{k}=2$ & 6,05 & 5,38 & 6,42 & 4,14 & 8,23 & 4,77 & 6,33 \\
$\mathrm{k}=3$ & 3,18 & 3,03 & 4,27 & 2,74 & 3,30 & 2,13 & 2,83 \\
\hline
\end{tabular}

Tabela 3.5: Valores do estimador de máxima verossimilhança para todas as condições farmacológicas, calculados fixando como máxima ordem 2. Todos os valores possuem uma probabi-

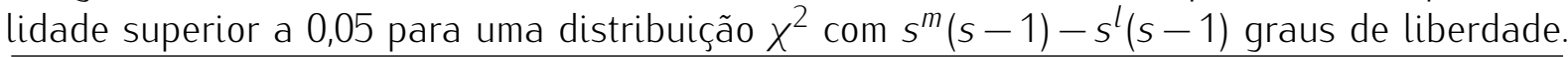

\begin{tabular}{rrrrrrrr}
\hline \multicolumn{3}{c}{ Ansiolítico } & Controle & \multicolumn{4}{c}{ Ansiogênico } \\
\hline & CPD & MDZ & & PTZ 10 mg/kg & PTZ 20 mg/kg & PTZ 30 mg/kg & SDZ \\
\hline $\mathrm{L}=1$ & 105,15 & 85,38 & 60,05 & 71,83 & 55,73 & 18,24 & 52,21 \\
$\mathrm{~L}=2$ & 2,03 & 1,56 & 1,38 & 1,14 & 3,53 & 1,89 & 1,68 \\
\hline
\end{tabular}

\subsection{Discussão}

A estratégia de considerar o comportamento exploratório do rato no interior do LCE como um processo de tomada de decisões e analisá-lo como se se tratasse de um processo de cadeias de Markov ofereceu informação importante sobre as preferências do animal. Neste sentido, as matrizes estocásticas captaram o comportamento médio dos ratos nos 5 minutos de sessão, e quando projetadas ao seu estado estacionário, vetores de valores de $\pi$, retornaram índices que caracterizam cada local do labirinto podendo ser úteis para diferenciar o comportamento do rato sob os efeitos de fármacos.

Observando as matrizes estocásticas, pode-se afirmar que em condições normais o rato 
prefere se deslocar em direção aos braços fechados, sobretudo quando ele se encontra nos braços abertos. Essa preferência representa o conflito e a aversão pelos braços abertos, indicando que o animal, mesmo quando sai a explorá-los, não se sente a vontade e prefere voltar para os braços fechados, como indicam as probabilidades maiores de virar em direção dos braços fechados que aparecem nas matrizes de transição. Poderia se pensar também que essas probabilidades refletem a interação entre as duas forças que, acredita-se, controlam o comportamento do animal e que dentro dessa representação reduzida podem ser equiparadas às preferências de direção. Por exemplo, uma maior preferência por ir em direção aos braços fechados indica um maior peso do componente aversivo, que incita o animal a evitar locais amedrontadores.

Esse resultado vê-se reforçado quando se calcula o vetor de valores de $\pi$, o qual deixa claro que sob condições controle é mais provável achar o animal nos bracos fechados, com uma probabilidade maior que $70 \%$. Ao distribuir essa probabilidade entre cada uma dos 11 locais que compõem o labirinto reduzido, pode-se observar que as probabilidades mais altas estão nas posições 9 e 10 (ver figura 3.7) que estão bem no meio do braço fechado e vão decaindo progressivamente a medida que o animal se aproxima do centro, chegando aos valores mais baixos no extremo do braço aberto.

Por outro lado, as matrizes de transição podem também refletir os efeitos farmacológicos de diferentes tipos de drogas, representando a maneira como o animal toma decisões sob os efeitos desses tratamentos. Desta maneira, sob os efeitos de um fármaco ansiogênico o padrão de decisões que o grupo controle apresentou vê-se acentuado, aumentando a probabilidade de se movimentar em direção dos braços fechados, como mostraram as matrizes de transições. Por sua vez, os vetores de valores de $\pi$ também representam uma acentuação do padrão observado nos grupos controle, aumentando ainda mais a probabilidade de se achar o rato nos braços fechados. Este resultado se ajusta perfeitamente à ideia de interação de forças e sua influência sob os efeitos de diferentes tipos de fármacos.

Além dos efeitos de fármacos ansiogênicos, as matrizes de transições e os vetores de $\pi$ representam também os efeitos de drogas ansiolíticas. Neste ponto encontra-se um dos resultados mais interessantes, porque tanto as matrizes de transições como os vetores de valores $\pi$ não apresentam padrões de preferência por uma direção ou por uma ou algumas posições. Desta maneira, os ratos sob os efeitos de fármacos ansiolíticos exploram o labirinto aleatoriamente, sem que seja possível determinar qual é a direção que ele irá tomar em um dado momento, ou em que posição é mais provável encontrá-lo. Este padrão das matrizes de transições se assemelha a um passeio aleatório (Wallisch et al., 2008) termo cunhado por 
Karl Pearson (Pearson, 1905) e que se refere precisamente a sistemas que mudam de estado de maneira aleatória.

Esses resultados são validados pelos resultados das avaliações da ordem da cadeia, nos que as cadeias de Markov de ordem um parecem ser apropiadas para capturar a informação suficiente para caracterizar o comportamento do rato no LCE. O que foi ratificado pelo teste de independência, cujos resultados indicam que as trajetórias que os animais fazem dentro do LCE não são independentes, e por tanto, há uma relação entre estar no estado $i$ tendo estado antes no estado $i$ para todos os grupos farmacológicos. Pudendo concluir que essas trajetórias seguem um padrão tipo Markov de uma ordem de pelo menos um.

Por outro lado, os resultados da avaliação da ordem da cadeia com os índices $A / C, B / C$ e estimador de máxima verossimilhança indicam que não se dispõe de informação suficiente para afirmar que seja necessário usar uma cadeia de ordem superior a um para caracterizar o comportamento exploratório de qualquer dos grupos farmacológicos. O que pode indicar que modelos de memória reduzida, como os modelos de cadeias de Markov, podem servir para capturar a informação necessária para reproduzir o processo de tomada de decisões dos ratos no LCE. Este resultado é interessante dado que foi encontrado ao se calcular o AIC, índice mais conservador com um termo de punição menor que o $B / C$, e com o estimador de máxima verossimilhança. Isto pode ser devido ao fato de que a exploração que o rato faz no interior do LCE não é guiada pela procura de uma recompensa, pois o rato não obtém nenhuma retroalimentação por exibir um determinado comportamento. Desta maneira, as trajetórias que o rato faz no interior do labirinto não seguem um padrão predominantemente marcado e é essa ausência de um padrão que se destaque que abre a possibilidade para a utilização de cadeias de Markov para a simulação do LCE.

Porém, é preciso mencionar que os graus de liberdade que corrigem as equações do AIC (3.12), do BIC (3.14) e que determinam o valor do $\chi^{2}$ a ser comparado no método de estimação de máxima verossimilhança, podem estar numa ordem de grandeza superior à do valor de $\eta_{k, m}$ obtido a partir dos registros dos animais. Isso pode se dever ao tamanho das amostras que está determinado pelo número de passos que os ratos fazem dentro do LCE. Neste sentido, é possível que a construção de um modelo de cadeias de Markov de tempo contínuo, a partir dos tempos de permanência do rato em cada local do labirinto, ofereça informação que permita confirmar os resultados aqui apresentados.

Em conclusão, consideramos que é possível a utilização de modelos tipo cadeias de Markov para simular e caracterizar o comportamento do rato no LCE sob efeitos de diferentes fármacos. Desta maneira, o cálculo das matrizes estocásticas e dos vetores de $\pi$ poderiam vir 
integrados no software de registro do animal e oferecer informação sobre o padrão de exploração do mesmo. Informação que poderia servir para classificar novos fármacos ou reavaliar os efeitos de fármacos já conhecidos. 


\section{Modelo conexionista para o comportamento exploratório do rato}

Uma vez atingidos os objetivos prévios de desenvolver métodos que permitam caracterizar e descrever o comportamento do rato, apresentados nos dois capítulos anteriores, neste capítulo será descrito o modelo computacional para o comportamento do rato no LCE. O modelo desenvolvido simula a maneira como ratos ou camundongos exploram ambientes novos, em outras palavras, simula uma exploração com um componente emocional. Este tipo de modelo se diferencia de modelos computacionais que descrevem a maneira como um organismo explora um ambiente guiado por uma recompensa (Voicu e Schmajuk, 2000) pelo fato de que a navegação é controlada pelo o conflito aproximação-evitação. A hipótese adotada nesta tese é a de que o comportamento do rato quando exposto ao LCE ou Arena é determinado pelo conflito aproximação-evitação.

O modelo se baseia em uma adaptação de um modelo conexionista capaz de processar informação conflitante (o modelo de Grossberg, 1980). A informação é conflitante porque provém de fontes diferentes, gerando um conflito para o organismo. Este conflito pode, em algumas ocasiões, levar o animal a evitar alguns locais e, em outras ocasiões, pode incitá-lo a explorá-los. No modelo de rede neural desenvolvido, a saída da rede determina a maneira como o animal explora o labirinto.

Os parâmetros da rede foram inicialmente ajustados para que a sua simulação reproduza o comportamento do rato no LCE, tanto para a condição controle como para condições sob efeitos de diferentes tipos de fármacos. Depois de se verificar que o organismo simulado reproduziu o comportamento do rato no LCE, ele foi levado para a Arena e testado nesse novo ambiente. A ideia foi utilizar o mesmo modelo para simular uma exploração típica de um rato submetido a diferentes tipos de fármacos em cada um dos labirintos, e comparar os valores dos parâmetros que melhor simulam cada labirinto na procura de entender o que caracteriza a exploração que se faz dentro de cada um.

Pretendeu-se com isso desenvolver um modelo computacional que reproduza a primeira 
exploração que um organismo realiza em um local, sem restringi-lo a um tipo específico de labirinto. Adicionalmente, atenção especial foi dada à maneira como diferentes tipos de fármacos afetam essa exploração, avaliando seus efeitos nos dois tipos de labirintos.

\subsection{Descrição do modelo}

O modelo computacional é um modelo de exploração com um componente emocional, dessa maneira pode-se considerá-lo como composto por dois sistemas integrados, um que simula o componente emocional e outro que está encarregado do sistema de navegação. O componente emocional é controlado pelo conflito aproximação-evitação que pode ser descrito como o resultado da competição entre duas tendências, uma que incita o organismo a explorar e outra que o incita a buscar proteção. Essas duas tendências podem ser representadas como dois sinais opostos que alimentam uma mesma rede. Essa rede possui duas possíveis saídas cada uma delas relacionada com um dos sinais de entrada.

A rede neural escolhida para modelar esse conflito é a conhecida como dipolo chaveado ("gated dipole") de Grossberg (Grossberg, 1980), por ser capaz de processar informação conflitante que provem de dois tipos diferentes de entradas. Originalmente, o modelo de dipolo chaveado de Grossberg foi desenvolvido para estudar uma situação de fuga e esquiva na qual um animal exposto a um estímulo aversivo, por exemplo um choque elétrico, consegue fugir desse estímulo apertando uma alavanca. Posteriormente, quando colocado na mesma situação o animal continuará emitindo o mesmo comportamento de apertar a alavanca, mesmo sem a presença do estímulo aversivo. A não apresentação do estímulo aversivo, porém, diminui a frequência de apresentação do comportamento até o ponto no qual o animal deixa de emiti-lo.

A rede que modela o sistema emocional possui duas unidades de entrada, uma que recebe informação que representa o estímulo aversivo e outra que recebe um sinal excitatório. Na presença do estímulo aversivo a saída da rede é diferente da saída na ausência do mesmo. Trabalhou-se com uma estrutura de rede similar à descrita em Grossberg, 1980 na qual há duas unidades de entrada, uma unidade de saída e três camadas de unidades de préprocessamento (ver figura 4.1 (a)), porém adicionou-se mais um sinal de entrada que somente estimula uma das unidades de entrada (ver figura 4.1 (b)). Isto com a finalidade de diferenciar os locais de ação dos fármacos, supondo que drogas ansiogênicas afetariam ao sistema em locais diferentes das drogas ansiolíticas.

As equações que descrevem o modelo são as seguintes: 


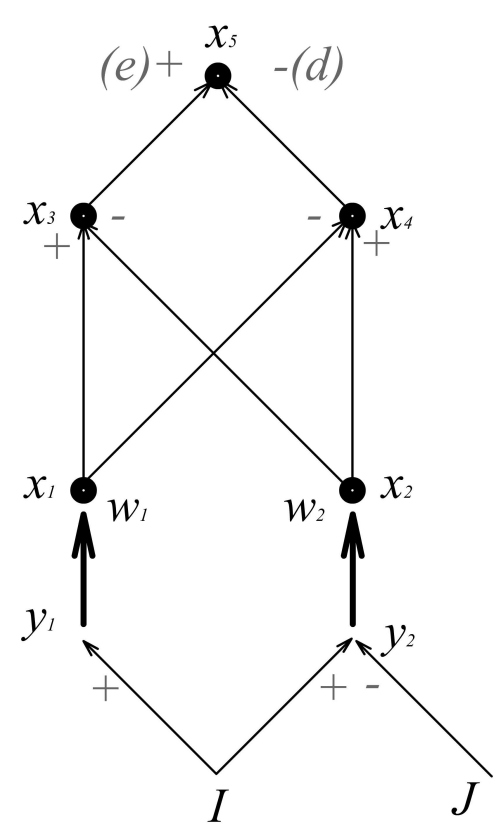

(a)

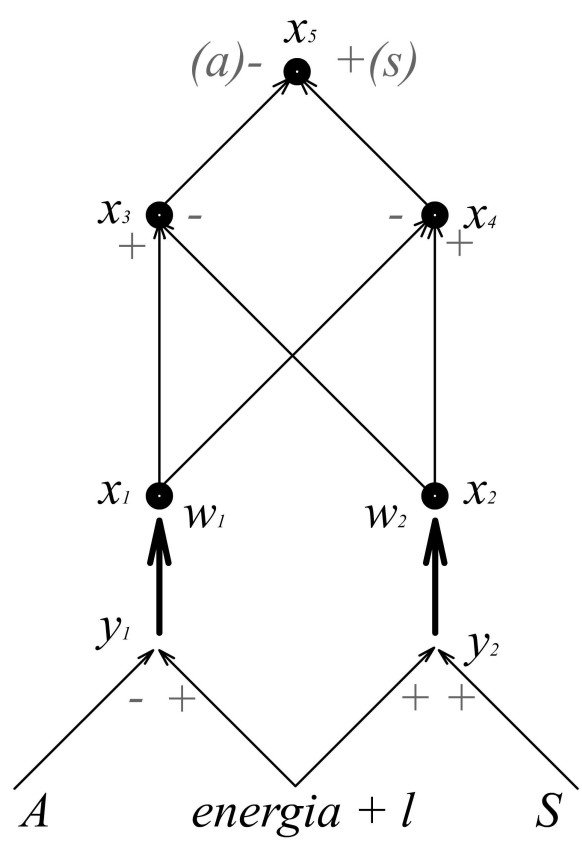

(b)

Figura 4.1: (a) Esquema original da rede de dipolo chaveado de Grossberg. (b) Esquema modificado que foi utilizado para modelar o sistema emocional. A entrada $A$ no esquema modificado representa a motivação para se deslocar na direção aos locais considerados aversivos, $S$ representa a motivação para se movimentar em direção aos locais considerados seguros, o termo energia representa o vigor do rato e o termo l representa a informação vinda do ambiente.

$$
\begin{aligned}
\frac{d y_{1}}{d t} & =-a y_{1}+\text { energia }+l+A \\
\frac{d y_{2}}{d t} & =-a y_{2}+\text { energia }+l+S \\
\frac{d w_{1}}{d t} & =b\left(M-w_{1}\right)-c y_{1} w_{1} \\
\frac{d w_{2}}{d t} & =b\left(M-w_{2}\right)-c y_{2} w_{2} \\
\frac{d x_{1}}{d t} & =-k x_{1}+m y_{1} w_{1} \\
\frac{d x_{2}}{d t} & =-k x_{2}+m y_{2} w_{2} \\
\frac{d x_{3}}{d t} & =-n x_{3}+p\left(x_{1}-x_{2}\right) \\
\frac{d x_{4}}{d t} & =-n x_{4}+p\left(x_{2}-x_{1}\right) \\
\frac{d x_{5}}{d t} & =-q x_{5}+\left(x_{4}-x_{3}\right) .
\end{aligned}
$$

As variáveis $x_{i}$ e $y_{i}$ que aparecem nas equações acima representam as atividades (saídas) 
das unidades mostradas na figura 4.1 (b). As variáveis $w_{1}$ e $w_{2}$ representam os pesos das sinapses conectando as unidades $y_{1}$ e $x_{1}$ e $y_{2}$ e $x_{2}$ respectivamente. Estas são as únicas sinapses modificáveis do modelo. A constante $M$ representa o máximo valor que os pesos dessas sinapses podem atingir (o mesmo valor para as duas sinapses). Os demais parâmetros que aparecem nas equações são constantes positivas. Os valores destes parâmetros, assim como os valores dos parâmetros que servem de sinais de entrada para a rede (ver abaixo), foram ajustados para que o modelo reproduza os comportamentos observados experimentalmente.

As unidades $y_{1}$ e $y_{2}$ do modelo recebem os sinais de entrada conforme descrito pelas equações 4.1 e a 4.2. Os sinais $A$ e $S$ representam as duas forças que caracterizam o conflito de aproximação-evitação. O sinal $A$ representa a motivação do animal a preferir permanecer ou explorar locais amedrontadores (sinal aversivo) e o sinal $S$ representa a motivação do animal a preferir permanecer ou explorar locais de aparente segurança (sinal excitatório). Os locais definidos como seguros são braços fechados, paredes e cantos e os locais definidos como amedrontadores são braços abertos, bordas dos braços abertos e espaços abertos

Os valores dos parâmetros $S$ e $A$ estão sujeitos à ação de fármacos ansiogênicos e ansiolíticos, podendo ser modulados por eles. Adicionalmente, o termo energia representa o vigor que um rato possui. Este parâmetro, por sua vez, pode ser afetado por um fármaco que afete a locomoção. Por último, o termo l representa o sinal vindo do ambiente informando ao animal que ele se encontra perto ou longe de um local amedrontador.

O sinal / foi calculado, para cada passo, seguindo a fórmula:

$$
l=\left(s_{x-1}+s_{x}+s_{x+1}\right)+\left(a_{x-1}+a_{x}+a_{x+1}\right),
$$

onde $x$ representa o local onde 0 rato se encontra, $x-1$ o local onde ele estava antes e $x+1$ o local justo na direção do seu movimento. A cada local do labirinto foi atribuído um valor de aversão $a_{i}$ e um valor de segurança $s_{i}$ dependendo da situação do animal em relação a ele: se está no local ou está se afastando ou se aproximando dele. Quando o local é um dos locais definidos como seguros e o animal estiver nele ou se aproximar dele, os seus valores são $s_{i}>0$ e $a_{i}=0$; por outro lado, se o local for definido como amedrontador e o animal estiver nele ou se aproximando dele os seus valores são $a_{i}<0$ e $s_{i}=0$.

Desta maneira, por exemplo, se o animal estiver na posição 9 de um braço fechado do LCE indo em direção ao centro do labirinto, como na figura 4.2, os valores de $s_{x-1}$ e $a_{x-1}$ $(x-1$ é a posição 10$)$ seriam $s_{10}>0$ e $a_{10}=0$ respectivamente; os valores de $s_{x}$ e $a_{x}$ ( $x$ é a posição 9) seriam $s_{9}>0$ e $a_{9}=0$; e os valores de $s_{x+1}$ e $a_{x+1}(x=1$ é a posição 8) seriam 
$s_{10}=0$ e $a_{10}<0$ respectivamente. Desta forma, a posição 8 , que se encontra na direção dos braços abertos quando o animal está na posição 9, é percebida pelo organismo como mais amedrontadora que a posição 10; porem, se o rato encontra-se na posição 7, a posição 8 será percebida como segura. A ideia por trás dessa representação é a de que as características de "segurança" ou de "aversão" de um lugar não dependem apenas da sua posição absoluta dentro do labirinto, mas também da posição do rato em relação a ele.

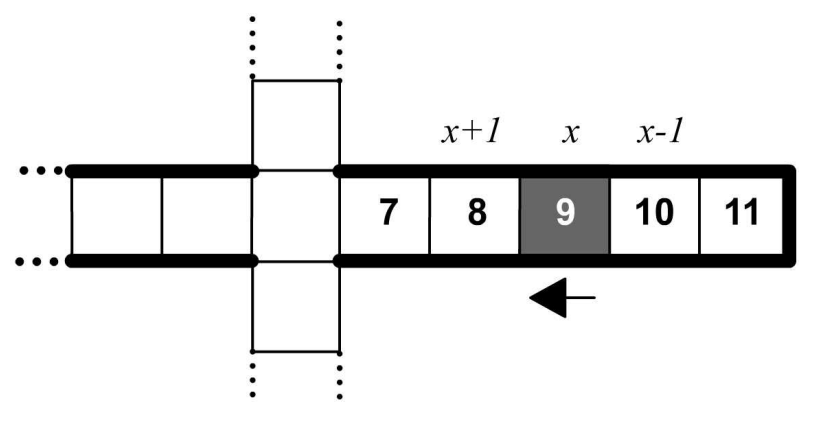

Figura 4.2: Representação das posições instantânea, passada e (possivelmente) futura do rato. A seta representa a direção na qual o animal transita num dado momento, indicando que o rato esteve na posição 10 (denominada $x-1$ ) antes de visitar a 9 (denominada de $x$ ), ficando a posição 8 na direção do movimento (denominada de $x+1$ ).

O comportamento do modelo depende dos sinais de entrada, os quais estimulam dois canais de processamento distintos: $y_{1} \longrightarrow x_{1} \longrightarrow x_{3}$ e $y_{2} \longrightarrow x_{2} \longrightarrow x_{4}$. Por exemplo, se 0 valor do sinal $S$ for maior que o de $A$ o canal da direita recebe uma entrada maior que 0 canal da esquerda. Devido ao sinal do canal direito ser maior que o esquerdo, a unidade $x_{2}$ terá uma saída maior que a de $x_{1}$ fazendo com que $x_{3}$ seja mais inibida que $x_{4}$. Isso provoca uma saída de $x_{4}$ maior que a de $x_{3}$ e faz com que $x_{5}$ seja estimulado positivamente, de maneira que o organismo tem uma maior probabilidade de se mover na direção que oferece mais segurança (letra $+(s)$ do lado da unidade $x_{5}$ no esquema (b) da figura 4.1). Por outro lado, se o sinal $A$ que entra pelo canal da esquerda for maior que o da direita, a atividade de $x_{1}$ será maior que a de $x_{2}$, a de $x_{3}$ maior que a de $x_{4}$ e, finalmente, $x_{5}$ será estimulado negativamente. Consequentemente, o animal terá uma maior probabilidade de se movimentar na direção do local amedrontador (letra $-(a)$ do lado da unidade $x_{5}$ no esquema (b) da figura 4.1). A saída da rede é comparada com valores que representam limiares que ela tem que atingir para que o organismo se mova em direção a um local seguro ou amedrontador. Se o valor da saída da rede for positivo e superior a um parâmetro denominado limiars, o animal possui uma probabilidade maior de se movimentar em direção ao local seguro; se a saída da rede for negativa e inferior a um parâmetro denominado limiar ${ }_{A}$, o animal tem uma probabilidade maior de se deslocar em direção ao local considerado como amedrontador. Esses limiares mudam com o tempo dificultando o deslocamento do animal e representando 
assim o decaimento da atividade do animal que é observado nos últimos minutos de uma sessão (Rosa et al., 2000).

Este modelo de rede, além de se ajustar aos requerimentos do projeto pelo tipo de informação que processa, possui um componente temporal que agrega precisão ao modelo permitindo obter medições tanto de padrões de deslocamentos quanto de padrões de preferência por locais, através da medição do tempo de permanência.

A saída da rede é posteriormente avaliada pelo sistema de navegação, o qual determina a decisão final sobre para onde o organismo vai se movimentar. O sistema de navegação discretiza espacialmente um labirinto (LCE ou Arena), dividindo-o em pequenos quadrados com aproximadamente o tamanho do animal de maneira que a cada instante de tempo o organismo se encontre em somente um local (ver figura 4.3 (a) e (e)). Além do chão, o organismo pode explorar as paredes e as bordas dos braços abertos, que são representados por quadrados que não pode ocupar (ver os quadrados de linhas tracejadas ao redor dos labirintos na figura 4.3 (a) e (e)). O organismo simulado explora o ambiente se movimentando do quadrado que atualmente ocupa para algum dos quadrados adjacentes e, no caso em que o organismo prefira explorar uma parede adjacente à sua posição atual, ele retornará a posição onde estava quando escolheu explorar a parede. Essa maneira de representar um deslocamento segue a premissa de que o organismo, ao explorar uma parede ou assomar sua cabeça pela borda dos braços abertos, tem suas patas traseiras apoiadas no chão do quadrado adjacente. Dessa maneira, uma vez terminada a exploração das paredes ou das bordas o organismo retorna ao quadrado adjacente no chão e continua sua exploração.

Para cada um dos locais adjacentes à posição atual é atribuído um valor aleatório que é modificado dependendo de duas condições: a direção definida pela rede que avalia o componente emocional e a direção da cabeça. O sistema de navegação se encarrega de escolher o local que possui o valor mais alto como o local que o organismo visitará no passo seguinte.

A interação do sistema de navegação com o LCE e a Arena está determinada por dois aspectos. O primeiro aspecto são os locais que o organismo pode ou não visitar, pois cada local do labirinto possui uma determinada configuração que limita a movimentação do organismo. Por exemplo, caso o organismo escolha explorar uma parede, essa exploração será considerada como uma exploração vertical ou "rearing". Assim, se o organismo se encontra na posição descrita na figura 4.3 (f) qualquer exploração dos quadrados 1, 2, 3, 6, 7, e 8 será considerada como vertical ou rearing. Seguindo a mesma lógica, quando o organismo se encontra dentro de um braço aberto do LCE como na figura 4.3 (g) qualquer exploração 
(a)

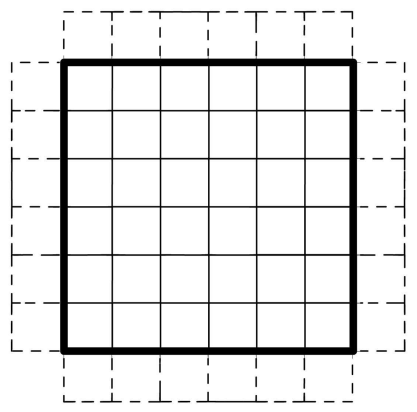

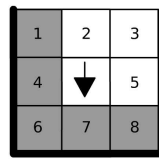

(b)

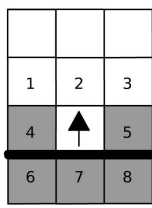

(c)

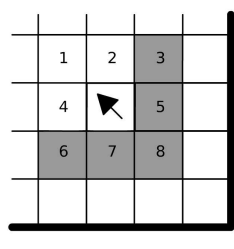

(d)

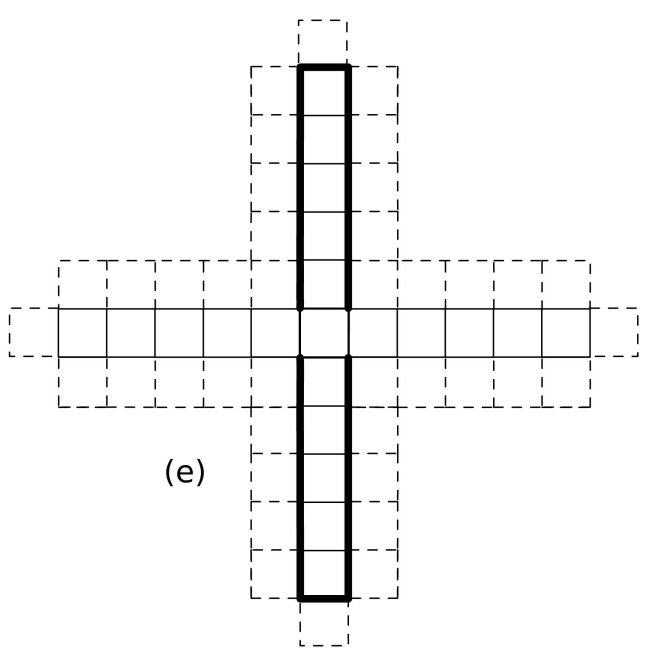

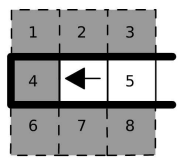

(f)

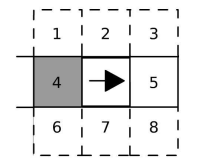

(g)

Figura 4.3: Discretização do espaço na Arena (a) e no LCE (e). Em b, c, d, f e g são apresentadas as atribuições de zona segura (quadrados cinza) ou zona amedrontadora (quadrados brancos) a cada um dos locais ao redor da posição que o organismo ocupa atualmente (representado no diagrama por uma seta que aponta na direção da cabeça do organismo). As figuras b, c e d representam as configurações de zonas para 3 locais da Arena: perto de um canto (b), encostado numa parede (c), e em direção ao centro (d). As figuras f e g mostram dois locais diferentes dentro do LCE: dentro dos braços fechados ( $f$ ) e dentro dos braços abertos (g).

aos quadrados 1, 2, 3, 6, 7 e 8 será considerada uma assomada na borda dos braços ou "head dipping".

O segundo aspecto que determina a interação entre o sistema de navegação e o labirinto são os valores de s e $a$ que cada local dentro do labirinto possui dependendo de sua localização absoluta e da sua posição em relação ao local que o rato está atualmente visitando. No LCE, como foi descrito anteriormente, qualquer posição que se encontre dentro dos braços fechados ou em direção a eles é considerada como um local que representa segurança. Do mesmo modo, qualquer posição nos braços abertos ou em direção a eles é considerada como um local amedrontador. Já na Arena, qualquer local que seja limítrofe às paredes ou que se encontre em direção a elas é considerado como seguro, e qualquer local que não faça limite com as paredes ou que esteja em direção ao centro é considerado como amedrontador. Desta maneira, num determinado momento, e dependendo da direção na qual o organismo esteja se deslocando, um local pode ser considerado como seguro ou amedrontador, como se pode ver 
na figura 4.3 (b, c, d, f e g).

Por último, é importante mencionar que, da mesma forma como feita nos estudos dos capítulos anteriores, a modelagem do LCE foi feita usando-se sua representação reduzida (Figura 4.4). Esse tipo de representação do LCE facilita a definição dos efeitos das forças que interagem e controlam o comportamento do animal, devido ao fato que o animal somente tem duas direções para as quais se locomover, direções que podem se equiparar com as duas possíveis preferências que o sistema emocional oferece como resultado.

\section{\begin{tabular}{|l|l|l|l|l|l|l|l|l|l|l|}
\hline 1 & 2 & 3 & 4 & 5 & 6 & 7 & 8 & 9 & 10 & 11 \\
\hline
\end{tabular}}

Figura 4.4: Esquema do LCE rebatido. Os quadrados numerados de 1 a 5 (cor cinza) representam os braços abertos. Os quadrados numerados de 7 a 11 (cor preta) representam os braços fechados, e o quadrado de número 6 representa a área central do labirinto.

\subsection{Método}

O modelo foi programado em Matlab (C1994-2010 The MathWorks, Inc.) e o sistema de equações diferenciais foi resolvido usando o método de Runge-Kutta de quarta ordem (Gilat e Subramaniam, 2000) com um valor de passo $k=0,05$. Depois da construção do programa, o próximo passo consistiu no ajuste dos seus parâmetros para adaptá-lo ao LCE. O ajuste de parâmetros foi realizado através de Algoritmos Genéticos (AG) (Mitchell, 1999) seguindo uma função de ajuste que será descrita com detalhes na seção seguinte. Uma vez atingido um bom ajuste em termos da similaridade entre as respostas do modelo e os registros dos animais, procedeu-se à identificação dos parâmetros cujas mudanças podem representar os efeitos de três diferentes fármacos: (a) drogas ansiolíticas, (b) drogas ansiogênicas e (c) drogas que aumentam a locomoção sem afetar a preferência pelos braços.

Depois de identificar os possíveis parâmetros capazes de representar os efeitos farmacológicos dos três fármacos mencionados acima, o passo a seguir foi testar o modelo na Arena. Dependendo dos resultados, o processo de ajuste de parâmetros foi repetido tomando como critério o comportamento do animal dentro da Arena para, finalmente, comparar os resultados obtidos no LCE com os resultados obtidos na Arena.

A seguir são descritos em detalhe os procedimentos que foram feitos para o ajuste de parâmetros e a identificação dos parâmetros cujas mudanças são capazes de reproduzir os efeitos dos três diferentes tipos de fármacos. 


\subsubsection{Ajuste do modelo}

Como escrito acima, o modelo foi inicialmente ajustado para reproduzir dados de ratos reais no LCE. Utilizando registros feitos no Laboratório de Comportamento Exploratório da USP de Ribeirão Preto, descritos nos anteriores capítulos (ver tabela 2.1, na página 13), para sua avaliação.

O ajuste dos parâmetros do modelo foi feito com algoritmos genéticos, por se tratar de uma excelente ferramenta de busca em espaços complexos que tem produzido bons resultados em diferentes aplicações (Wang, 1997 e Chen, Jakeman e Norton, 2008). Os AG usam alguns conceitos tomados da biologia evolutiva como mutação, cruzamento, seleção natural e os aplicam na construção de algoritmos de busca dentro de um espaço de parâmetros. A ideia é partir de um conjunto de grupos de números aleatórios, que representam alguns dos possíveis valores que cada um dos parâmetros pode assumir. Esse conjunto compõe a população na geração 0 , que é testada no problema em questão e avaliada segundo algum critério específico (função de fitness). Os parâmetros que fornecerem um melhor ajuste segundo o critério adotado formarão a geração seguinte. No processo de formação da nova geração entram em jogo os conceitos de seleção natural, introduzindo novos indivíduos, estabelecendo critérios para criar novos indivíduos a partir do cruzamento dos antigos ou provocando mutações. Esse processo leva a uma exploração aleatória do espaço de parâmetros, achando um conjunto deles que se ajusta aos critérios definidos. Todos os parâmetros do modelo foram ajustados usando AG, tanto aqueles que definem a estrutura da rede de Grossberg, quanto aqueles que descrevem o sistema emocional e o sistema de navegação. Uma lista com os parâmetros que foram ajustados é apresentada na tabela 4.1. Foram utilizados 500 indivíduos por geração, com elitismo de 5\%, reprodução aleatória dos melhores 100 indivíduos e inclusão de 275 novos indivíduos em cada geração, e uma taxa de mutação de 5\%. Tanto para o processo de cruzamento quanto para as mutações os parâmetros foram convertidos em números binários. Desta maneira, para o cruzamento era escolhida uma posição aleatória do número binário que determinava o ponto de corte e combinava-se a primeira parte do número de um individuo com a segunda parte de outro indivíduo e vice-versa para gerar dois filhos da nova geração. Na mutação era novamente escolhida aleatoriamente uma posição do número binário que representava um determinado parâmetro e trocava-se seu valor pelo valor oposto, de 0 para 1 e vice-versa.

O critério de ajuste estava baseado na ideia de reproduzir o comportamento padrão de um rato submetido a uma única sessão de 5 minutos no LCE sem tratamentos farmacológicos. É por isso que a função de ajuste, como é mostrada na seguinte equação, valorizava a proporção 
de entradas $(P E B F)$ e o tempo de permanência nos braços fechados (PTBF), juntamente com a semelhança entre o padrão de exploração simulado e o padrão de exploração de ratos reais. Essa semelhança foi calculada como a média dos coeficientes de correlação de Pearson (r) calculados entre o padrão simulado e 4 padrões de ratos reais registrados no Laboratório de Comportamento Exploratório da USP de Ribeirão Preto.

Os melhores indivíduos das diferentes gerações foram testados calculando-se os parâmetros clássicos usados para avaliar o comportamento do rato no LCE: número médio de entradas nos braços fechados, tempo de permanência nos braços fechados e número de cruzamentos entre os braços fechados e abertos. O teste usado foi o teste $t$ de amostras emparelhadas com um valor alfa de 0,05 . Adicionalmente, foram estimados os valores do índice $\pi$ para cada um dos locais do labirinto. Esta informação foi cruzada procurando achar um conjunto de parâmetros que se ajustasse bem a todos os diferentes critérios.

$$
\text { Ajuste }=P T B F * P E B F * \bar{r}
$$

Tabela 4.1: Relação de parâmetros do modelo que foram ajustados com os algoritmos genéticos

\begin{tabular}{|c|c|}
\hline Nome do Parâmetro & Descrição \\
\hline$s_{i}$ & Valor de segurança atribuído a cada local do labirinto \\
\hline$a_{i}$ & Valor de aversão atribuído a cada local do labirinto \\
\hline Limiars & $\begin{array}{l}\text { Valor que a saída da rede do sistema de emocional deve } \\
\text { superar para que se prefira visitar os locais considerados } \\
\text { como seguros }\end{array}$ \\
\hline LimiarA $_{A}$ & $\begin{array}{l}\text { Valor que a saída da rede do sistema de emocional deve } \\
\text { superar para que se prefira visitar os locais considerados } \\
\text { como amedrontadores }\end{array}$ \\
\hline$o, b, c, k, r, n, p, q$ & Parâmetros próprios do modelo \\
\hline A & $\begin{array}{l}\text { Valor da motivação para se deslocar na direção dos locais } \\
\text { considerados como amedrontadores }\end{array}$ \\
\hline S & $\begin{array}{l}\text { Valor da motivação para se deslocar na direção dos locais } \\
\text { considerados como seguros }\end{array}$ \\
\hline Energia & Nível de energia do animal num dado momento \\
\hline Cabeça & $\begin{array}{l}\text { Peso atribuído ao local que se encontre em direção da } \\
\text { cabeça no momento da tomada de decisão }\end{array}$ \\
\hline
\end{tabular}




\subsubsection{Identificação dos parâmetros cujas mudanças representam efeitos farmacológicos}

Posteriormente à etapa de ajuste de parâmetros, procedeu-se à exploração dos efeitos das variações de cada um dos parâmetros sobre o comportamento do modelo. Nesta etapa a atenção foi focada naqueles parâmetros que têm relação com aspectos etológicos ou comportamentais, como os parâmetros que descrevem o sistema emocional e o sistema de navegação. Foram avaliados os efeitos das variações aumentado-se ou diminuindo-se o valor de um parâmetro ou de um conjunto deles. O objetivo dessas variações foi o de identificar parâmetros que possam representar os efeitos de fármacos sobre o comportamento do rato. As proporções das variações (aumento ou diminuição) foram, no máximo, de 10 vezes o valor originalmente obtido com os AG.

Como critérios de avaliação foram utilizados a média de: entradas, tempo de permanência e distância percorrida em cada um dos dois tipos de braços, comparando-se os resultados simulados de um conjunto de ratos em condições controle com os obtidos a partir de cada uma das modificações dos parâmetros. Para comparar os efeitos das mudanças dos parâmetros no comportamento do organismo foram utilizados o teste $t$ de comparação de médias, quando foram comparados os desempenhos de dois grupos, e uma ANOVA de uma via, para comparações entre os desempenhos de mais de dois grupos. Em todos os casos o valor de alfa foi de 0,05. Adicionalmente, foram calculados o índice de exploração, como foi descrito no capítulo 2 e em Tejada et al., 2009, e calculadas as matrizes de transição e os vetores de valores de $\pi$, como foi descrito no capítulo 3, para cada condição farmacológica.

\subsubsection{Teste do modelo na Arena}

O passo seguinte após a consolidação do modelo para o LCE foi testá-lo na Arena. Isso foi feito aplicando o modelo desenvolvido para o LCE à Arena, sem nenhuma modificação além das restrições próprias da estrutura do labirinto, que para o caso significaram uma ampliação das possibilidades de movimentos que o modelo tinha no LCE.

O desempenho do organismo simulado na Arena foi avaliado usando os critérios clássicos de análise nesse labirinto, comparando a porcentagem de tempo de permanência e de deslocamentos realizados perto das paredes com os feitos na área central do labirinto. Foi utilizado o teste $t$ de comparação de médias para avaliar os efeitos das mudanças nos parâmetros quando comparados com o grupo controle, na procura de identificar quais modificações podem representar os efeitos dos três tipos de drogas trabalhadas no LCE. 
Na hipótese de o modelo treinado no LCE não apresentar um bom ajuste na Arena, a metodologia seguida é a de realizar nova exploração com AG com o objetivo de procurar um conjunto de parâmetros que represente melhor o comportamento do animal na Arena. Essa exploração seguiria os mesmos critérios da exploração com AG utilizados para o LCE.

\subsection{Resultados}

Os resultados serão organizados apresentando inicialmente o modelo desenvolvido para o LCE seguido pelos resultados encontrados para o modelo na Arena.

\subsubsection{Labirinto em Cruz Elevado}

Através da utilização dos algoritmos genéticos foram encontrados vários conjuntos de parâmetros com um bom ajuste. Porém, somente após 167 gerações obteve-se um conjunto de parâmetros que foi considerado satisfatório (ver os valores na tabela C.1 do apêndice C). Esse conjunto de parâmetros é capaz de gerar grupos de indivíduos que se assemelham com os resultados obtidos com animais controle. Desta forma, o modelo com esse conjunto de parâmetros será chamado aqui de modelo controle.

Os animais do modelo controle simulados fizeram em média mais entradas nos braços fechados $\left(t_{[20]}=7,7122\right.$ e $\left.P<0,05\right)$ e também permaneceram em média por mais tempo neles $\left(t_{[20]}=6,1293\right.$ e $\left.P<0,05\right)$. Além da semelhança com os resultados ao final da sessão de 5 minutos, o padrão de exploração observado no interior de cada braço é parecido com o padrão de exploração de ratos controle, como se pode ver na figura 4.5.

Como parte da avaliação dos resultados da simulação, foram calculadas as matrizes de probabilidades de transições e usadas para estimar os valores dos índices $\pi$ para cada grupo de ratos, seguindo o procedimento descrito no capítulo 3 do presente documento. Os valores das matrizes obtidos a partir das simulações se assemelham com as matrizes obtidas a partir de registros de animais, apresentando o mesmo padrão de preferência para retornar aos braços fechados quando estão explorando os braços abertos. Já no interior dos braços fechados essa preferência desaparece da mesma maneira como foi observado nos animais (ver figura 4.6 (a)). Os valores de $\pi$ calculados com os dados simulados (ver figura 4.6 (b)) apresentam o mesmo padrão observado nos animais reais, com uma probabilidade de se encontrar o organismo nos braços fechados de 68\%, valor similar ao encontrado em animais.

Com todos esses resultados pode-se afirmar que o conjunto de parâmetros escolhido 


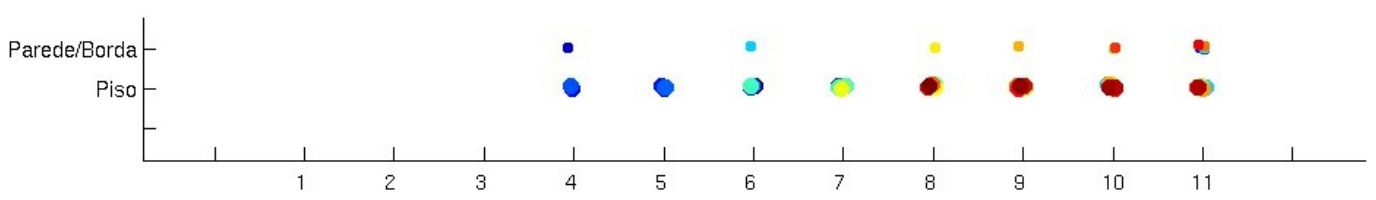

(a)

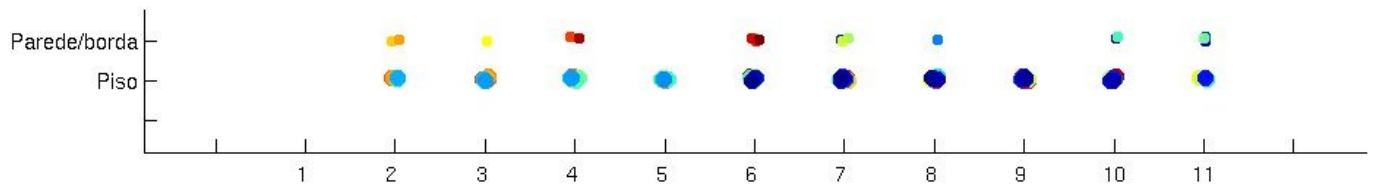

(b)

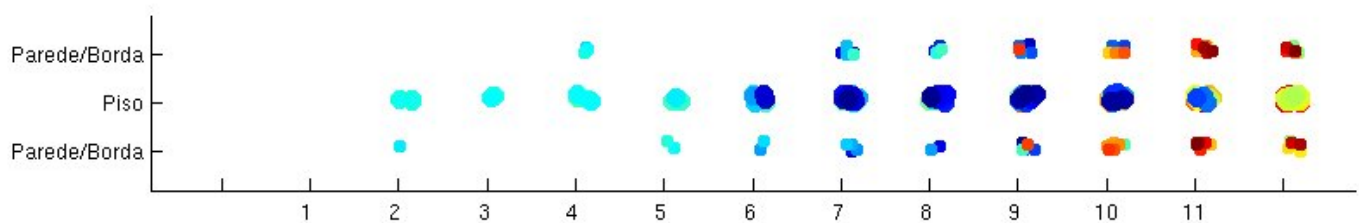

(c)

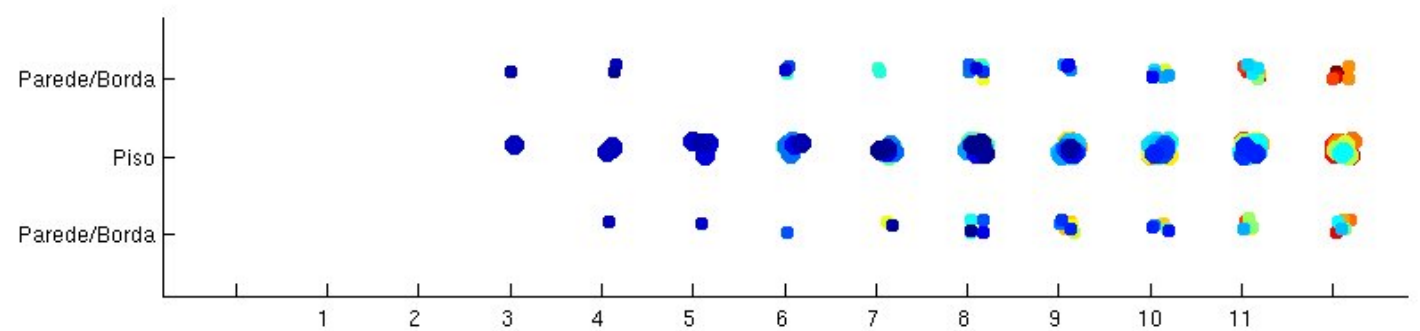

(d)

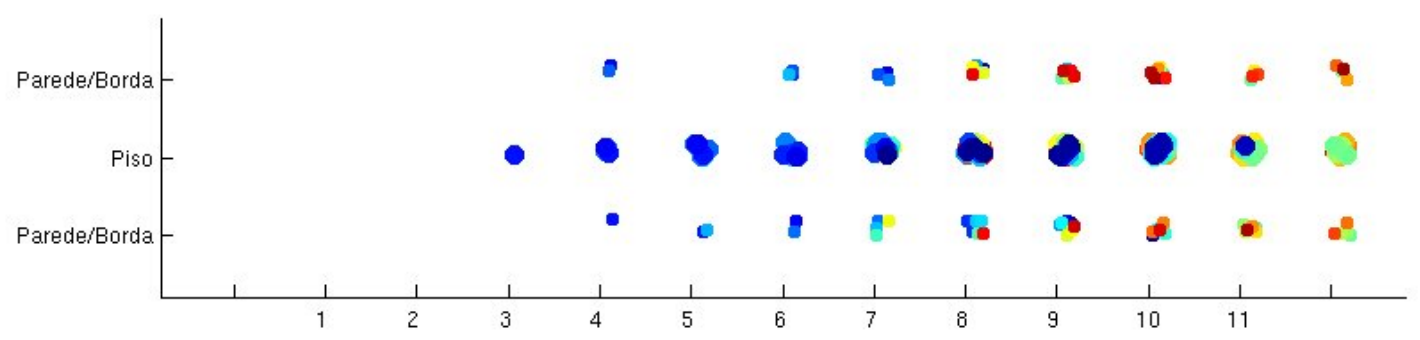

(e)

Figura 4.5: Gráficos que apresentam o padrão de exploração de animais controle reais (a e b) e simulados (c, d e e) submetidos ao LCE. Os números no eixo $x$ representam cada um dos 11 quadrados nos quais foi dividido o labirinto. No eixo y se identifica se o deslocamento foi feito no piso ou nas paredes. Os pontos na linha do piso representam uma visita do animal ao respectivo quadrado e os pontos na linhas das paredes, representam uma exploração feita a uma parede ou a uma borda. As cores representam o momento no qual acontecera a exploração, sendo azuis para as primeiras explorações, verde para aquelas que aconteceram na metade da sessão e vermelha para as que aconteceram no final. 


$$
\mathbb{Q}=\left(\begin{array}{ccccccccccc}
0 & 1,00 & 0 & 0 & 0 & 0 & 0 & 0 & 0 & 0 & 0 \\
0,44 & 0 & 0,56 & 0 & 0 & 0 & 0 & 0 & 0 & 0 & 0 \\
0 & 0,45 & 0 & 0,55 & 0 & 0 & 0 & 0 & 0 & 0 & 0 \\
0 & 0 & 0,44 & 0 & 0,56 & 0 & 0 & 0 & 0 & 0 & 0 \\
0 & 0 & 0 & 0,34 & 0 & 0,66 & 0 & 0 & 0 & 0 & 0 \\
0 & 0 & 0 & 0 & 0,36 & 0 & 0,64 & 0 & 0 & 0 & 0 \\
0 & 0 & 0 & 0 & 0 & 0,48 & 0 & 0,52 & 0 & 0 & 0 \\
0 & 0 & 0 & 0 & 0 & 0 & 0,53 & 0 & 0,47 & 0 & 0 \\
0 & 0 & 0 & 0 & 0 & 0 & 0 & 0,48 & 0 & 0,52 & 0 \\
0 & 0 & 0 & 0 & 0 & 0 & 0 & 0 & 0,51 & 0 & 0,49 \\
0 & 0 & 0 & 0 & 0 & 0 & 0 & 0 & 0 & 1,00 & 0
\end{array}\right)
$$

(a)

\begin{tabular}{ccccccccccc}
\hline 1 & 2 & 3 & 4 & 5 & 6 & 7 & 8 & 9 & 10 & 11 \\
\hline 0,02 & 0,05 & 0,05 & 0,04 & 0,06 & 0,10 & 0,14 & 0,15 & 0,15 & 0,16 & 0,08 \\
\hline
\end{tabular}

(b)

Figura 4.6: (a) Matriz estocástica com as probabilidades de transição calculadas para um grupo de 20 animais simulando uma situação controle. (b) Valores de $\pi$ calculados a partir da matriz estocástica, para cada um dos 11 locais nos que foi dividido o LCE rebatido.

reproduz adequadamente o comportamento de ratos controle. O modelo com esse conjunto de parâmetros (modelo controle) será utilizado como ponto de partida para identificar as variáveis cujas mudanças podem representar os efeitos de diferentes fármacos sobre o comportamento. Inicialmente, as mudanças sobre os parâmetros foram agrupadas em três subconjuntos: (a) aquelas que representam os efeitos de uma droga ansiogênica; (b) aquelas que representam uma droga ansiolítica; e, por último, (c) as que representam uma droga que afeta a locomoção.

Dentro do primeiro grupo trabalharam-se parâmetros que dificultassem a exploração dos braços abertos do labirinto diminuindo os sinais que estimulam o canal esquerdo da rede do sistema emocional. Por exemplo, usou-se valores baixos para parâmetros como A. Também se tentou incrementar as chances de que o organismo prefira transitar em direção aos braços fechados, diminuindo os valores de Limiars ou dificultando a preferência pelos braços abertos, aumentando os valores absolutos de LimiarA. Finalmente, e como produto da exploração, encontrou-se que modificações no parâmetro que representa a preferência por continuar a exploração na direção da cabeça produzem padrões de comportamento que se ajustam a este primeiro grupo.

Já no segundo grupo trabalhou-se com parâmetros opostos aos usados no primeiro grupo, explorando valores altos em parâmetros como $A$ ou valores baixos em $S$. Trabalharam-se também mudanças nos valores dos limiares, porém sem achar o padrão esperado.

Por último, no terceiro grupo está o parâmetro energia, para o qual valores altos pro- 
duzem aumento na locomoção sem afetar o padrão de preferências de espaços; da mesma maneira, a redução da energia diminui a atividade do organismo, também sem afetar a preferência pelos braços fechados. As tabelas 4.2, 4.3 e 4.4 resumem os melhores resultados. Estes foram obtidos no processo de avaliação dos efeitos das variações dos parâmetros, comparando-se através de um teste $t$ os resultados para um grupo de 20 ratos obtidos a partir de cada uma das mudanças dos parâmetros com os resultados para um grupo controle de mesmo tamanho de ratos simulados. Da mesma maneira, a tabela 4.5 apresenta o índice médio de exploração calculado para 10 amostras de ratos simulados com os mesmos parâmetros, onde cada uma das amostras simulava um grupo de 10 ratos submetidos ao LCE. Finalmente, na tabela 4.6 são apresentados os índices $\pi$ calculados para cada uma das 11 posições do labirinto e para cada um dos grupos de 10 ratos para os quais foi calculado o índice de exploração.

Nessas tabelas as mudanças nos parâmetros que reproduziram os efeitos de uma droga ansiolítica estão sinalizadas com a cor cinza claro, os que reproduzem os efeitos de uma droga ansiogênica com a cor cinza escuro e os que reproduzem os efeitos de drogas que aumentam a exploração com a cor preta.

Todas as três condições que se pretendia simular foram reproduzidas com a mudança isolada de um parâmetro. O parâmetro energia, tanto com valores altos quanto baixos, apresenta padrões claros dos efeitos de drogas que aumentam ou diminuem a locomoção. Da mesma maneira, valores altos no parâmetro $A$ mostraram um padrão de comportamento similar ao observado em ratos sob os efeitos de drogas ansiolíticas. De igual forma, valores absolutos altos no parâmetro Limiar e valores baixos nos parâmetros Cabeça e Limiars reproduzem o comportamento observado em ratos sob ação de drogas ansiogênicas.

Em termos gerais, a exploração dos parâmetros ofereceu resultados que se encaixam dentro do esperado. As mudanças nos parâmetros que aumentam a preferência pelos braços abertos têm padrões de comportamento parecidos aos dos animais submetidos a drogas ansiolíticas, aumentando o tempo e as entradas nos braços abertos ao mesmo tempo que apresentaram valores do índice de exploração inferiores aos do grupo controle. Eles também apresentam um padrão de valores do índice $\pi$ para os quais é igualmente provável achar o rato em qualquer dos locais do labirinto (ver tabelas 4.2, 4.3, 4.4 e 4.5, especificamente nas linhas de cor cinza escuro).

Da mesma maneira, mudanças nos parâmetros que aumentam a preferência pelos braços fechados têm padrões similares aos observados em animais sob efeitos de drogas ansiogênicas. Elas diminuem as entradas e o tempo de permanência nos braços abertos, apresentam valores 
Tabela 4.2: Resultados dos testes $t$ para diferenças de médias de entradas nos braços do labirinto rebatido, calculados entre um grupo de 20 ratos simulando condições controle (Ctrl) e um grupo de 20 ratos simulados a partir de conjuntos diferentes de parâmetros (Expl). Cada um dos conjuntos teve mudanças nos valores dos parâmetros especificados na primeira coluna. As modificações podiam ser VA para valores altos do parâmetro ou VB para valores baixos.

\begin{tabular}{|c|c|c|c|c|}
\hline ENTRADAS & \multicolumn{2}{|r|}{ Braços Fechados } & \multicolumn{2}{|r|}{ Braços Abertos } \\
\hline Parâmetro & \multicolumn{2}{|r|}{ "Diferença Ctrl - Expl } & \multicolumn{2}{|c|}{ Diferença Ctrl - Expl } \\
\hline LimiarA VA $_{A}$ & 2,45 & $t_{[38]}=2,05 ; P=0,05$ & 1,50 & $t_{[38]}=2,57 ; P=0,01$ \\
\hline Limiars VB & 2,50 & $t_{[38]}=2,48$ & 1,36 & $t_{[38]}=2,24 ; P=0,03$ \\
\hline Cabeça VA & 4,85 & $t_{[38]}=5,47$ & 2,20 & $t_{[38]}=4,36 ; P=0$ \\
\hline Cabeça VB & 4,55 & $t_{[38]}=4,48 ; P=0$ & 4,45 & $t_{[38]}=10,02 ; P=0$ \\
\hline Energia VB & 6,40 & $t_{[38]}=7,16 ; P=0$ & 1,80 & $t_{[38]}=3,63 ; P=0$ \\
\hline Energia VA & $-7,45$ & $t_{[38]}=-5,75 ; P=0$ & $-4,40$ & $t_{[38]}=-6,67 ; P=0$ \\
\hline A VA & 1,55 & $t_{[38]}=1,75 ; P=0,08$ & $-1,50$ & $t_{[38]}=-2,02 ; P=0,04$ \\
\hline Limiar $_{A}$ VA + energia VB & 4,70 & $t_{[38]}=5,04 ; P=0$ & 2,65 & $t_{[38]}=4,79 ; P=0$ \\
\hline Limiars VB + energia VB & 4,35 & $t_{[38]}=4,57 ; P=0$ & 2,25 & $t_{[38]}=3,87 ; P=0$ \\
\hline A VB + energia VA & $-3,65$ & $t_{[38]}=-2,33 ; P=0,03$ & $-2,85$ & $t_{[38]}=-3,27 ; P=0$ \\
\hline$S V A+\operatorname{Limiar}_{A} V A$ & 1,70 & $t_{[38]}=1,59 ; P=0,12$ & $-2,60$ & $t_{[38]}=-2,74$ \\
\hline
\end{tabular}

de índice de exploração superiores aos do grupo controle e possuem padrões de valores do índice $\pi$ nos quais é mais provável achar o rato nos braços fechados (ver tabelas 4.2, 4.3, 4.4 e 4.5 linhas na cor cinza claro).

Nas figuras 4.7 (a), (b) e (c) se comparam os resultados obtidos ao reproduzir os efeitos de drogas ansiolíticas e ansiogênicas em relação ao modelo de controle. As medidas usadas nessa comparação foram as médias de entradas, de porcentagem de tempo de permanência e de cruzamentos. Nessas figuras pode-se ver que as simulações se ajustam aos resultados esperados em termos dos critérios clássicos de avaliação dos efeitos das drogas. Os organismos simulados apresentaram diferenças significativas no número de entradas $\left(F_{g l_{[2 ; 5]}}=21,75\right)$, na porcentagem de tempo gasto $\left(F_{g l_{[2 ; 57]}}=15,75\right)$ e nos cruzamentos $\left(F_{g l[2 ; 5]}=23,99\right)$ nos braços abertos quando comparados com o grupo controle. Em todos os casos as mudanças foram significativas e na direção esperada: aumento de entradas e de tempo de permanência nos braços abertos como resultado das drogas ansiolíticas; e diminuição das entradas nesses mesmos braços como efeitos das drogas ansiogênicas.

Além disso, quando avaliadas através do índice $\pi$ (ver figura 4.8) as simulações apresentam um padrão de probabilidade de ocupação de espaço similares às observadas nos ratos reais (ver figura 3.7 na página 32).

O padrão mais fácil de ser reproduzido foi o de drogas ansiogênicas, que se conseguiu reproduzir com mudanças de até dois parâmetros. Por outro lado, o padrão de drogas ansiolí- 
Tabela 4.3: Resultados dos testes $t$ para diferenças de médias da porcentagem de tempo de permanência nos braços do labirinto rebatido, calculados entre um grupo de 20 ratos simulando condições controle $(\mathrm{Ctrl})$ e um grupo de 20 ratos simulados a partir de conjuntos diferentes de parâmetros (Expl). Cada um dos conjuntos teve mudanças nos valores dos parâmetros especificados na primeira coluna. As modificações podiam ser VA para valores altos do parâmetro ou VB para valores baixos.

\begin{tabular}{lrrrr}
\hline TEMPO & \multicolumn{3}{c}{ Braços Fechados } & \multicolumn{2}{c}{ Braços Abertos } \\
\hline \hline Parâmetro & \multicolumn{3}{c}{ Diferença Ctrl - Expl } & \multicolumn{2}{c}{ Diferença Ctrl - Expl } \\
\hline \hline Limiar VA & $-0,05$ & $t_{[38]}=-0,74 ; \mathrm{P}=0,46$ & 0,05 & $t_{[38]}=0,74 ; \mathrm{P}=0,46$ \\
Limiars VB & $-0,16$ & $t_{[38]}=-3,14 ; \mathrm{P}=0,003$ & 0,16 & $t_{[38]}=3,14 ; \mathrm{P}=0$ \\
Cabeça VA & 0,01 & $t_{[38]}=0,11 ; \mathrm{P}=0,92$ & $-0,01$ & $t_{[38]}=-0,11 ; \mathrm{P}=0,92$ \\
Cabeça VB & $-0,29$ & $t_{[38]}=-6,95 ; \mathrm{P}=0$ & 0,29 & $t_{[38]}=6,95 ; \mathrm{P}=0$ \\
Energia VB & 0,28 & $t_{[38]}=3,49 ; \mathrm{P}=0$ & $-0,28$ & $t_{[38]}=-3,49 ; \mathrm{P}=0$ \\
Energia VA & 0,03 & $t_{[38]}=0,47 ; \mathrm{P}=0,64$ & $-0,03$ & $t_{[38]}=-0,47 ; \mathrm{P}=0,64$ \\
A VA & 0,17 & $t_{[38]}=3,04 ; \mathrm{P}=0$ & $-0,17$ & $t_{[38]}=-3,81 ; \mathrm{P}=0$ \\
\hline LimiarA VA + energia VB & $-0,07$ & $t_{[38]}=-0,92 ; \mathrm{P}=0,36$ & 0,07 & $t_{[38]}=0,92 ; \mathrm{P}=0,36$ \\
LimiarS VB + energia VB & $-0,15$ & $t_{[38]}=-2,68 ; \mathrm{P}=0,01$ & 0,15 & $t_{[38]}=2,68 ; \mathrm{P}=0,01$ \\
A VB + energia VA & 0,19 & $t_{[38]}=2,96 ; \mathrm{P}=0,01$ & $-0,19$ & $t_{[38]}=-2,96 ; \mathrm{P}=0,01$ \\
S VA + Limiar VA & 0,24 & $t_{[38]}=3,78 ; \mathrm{P}=0$ & $-0,24$ & $t_{[38]}=-3,78 ; \mathrm{P}=0$
\end{tabular}

\section{$\square$ A VA $\square$ Controle $\square$ Limiar s VB + Energia VB}

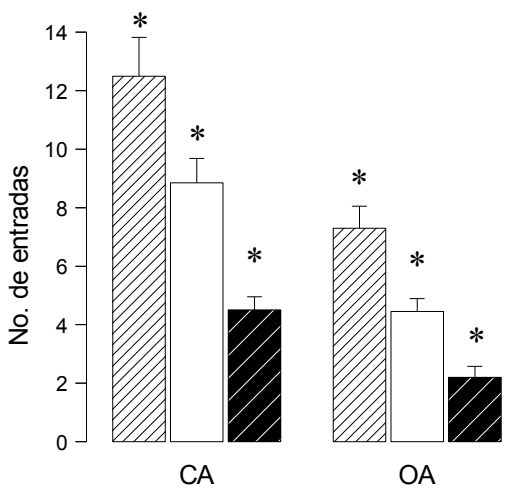

(a)

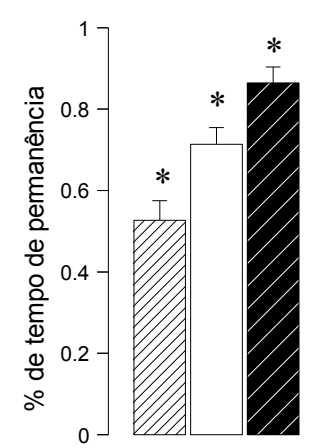

$\mathrm{CA}$

(b)

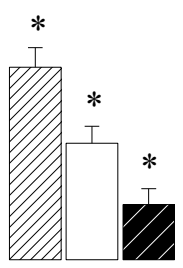

$\mathrm{OA}$

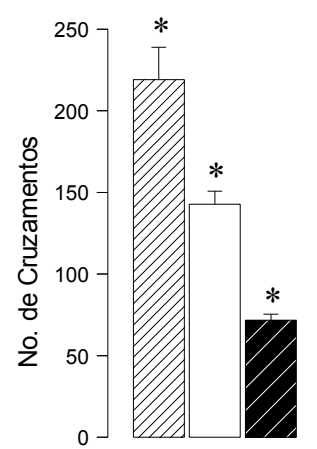

$\mathrm{CA}$

(c)

Figura 4.7: Gráfico de barras comparando (a) número de entradas, (b) porcentagem de tempo de permanência e (c) cruzamentos no labirinto rebatido de três grupos farmacológicos simulados: grupo controle, grupos submetido a drogas ansiogênicas (Limiars VB + energia VB ) e grupos submetido a drogas ansiolíticas ( $A \vee A)$. Os asteriscos representam diferenças significativas ( 0,05$)$ calculadas com uma ANOVA de uma via $(g l[2 ; 57])$.

ticas foi o mais difícil de reproduzir, necessitando de mudanças em três parâmetros diferentes para ser atingido.

Os parâmetros cujas variações não produziram comportamentos que se distanciaram significativamente dos do modelo de controle a ponto de poder ser consideradas como efeitos de drogas não foram apresentados. 
Tabela 4.4: Resultados dos testes $t$ para diferenças de médias dos cruzamentos no labirinto rebatido, calculados entre um grupo de 20 ratos simulando condições controle (Ctrl) e um grupo de 20 ratos simulados a partir de conjuntos diferentes de parâmetros (Expl). Cada um dos conjuntos teve mudanças nos valores dos parâmetros especificados na primeira coluna. As modificações podiam ser VA para valores altos do parâmetro ou VB para valores baixos.

\begin{tabular}{lrlrl}
\hline CRUZAMENTOS & \multicolumn{2}{c}{ Braços Fechados } & \multicolumn{2}{c}{ Braços Abertos } \\
\hline \hline Parâmetro & \multicolumn{2}{c}{ Diferença Ctrl - Expl } & \multicolumn{2}{c}{ Diferença Ctrl - Expl } \\
\hline \hline LimiarA VA & 39,60 & $t_{[38]}=3,61 ; \mathrm{P}=0$ & 1,40 & $t_{[38]}=0,26 ; \mathrm{P}=0,79$ \\
Limiars VB & 8,84 & $t_{[38]}=0,96 ; \mathrm{P}=0,34$ & $-9,30$ & $t_{[38]}=-0,98 ; \mathrm{P}=0,33$ \\
Cabeça VA & 35,15 & $t_{[38]}=3,12 ; \mathrm{P}=0$ & $-5,05$ & $t_{[38]}=-0,95 ; \mathrm{P}=0,35$ \\
Cabeça VB & $-15,7$ & $t_{[38]}=-1,92 ; \mathrm{P}=0,06$ & 22,35 & $t_{[38]}=8,72 ; \mathrm{P}=0$ \\
\hline Energia VB & 124,90 & $t_{[38]}=14,6 ; \mathrm{P}=0$ & $-0,85$ & $t_{[38]}=-0,22 ; \mathrm{P}=0,83$ \\
Energia VA & $-134,80$ & $t_{[38]}=-6,92 ; \mathrm{P}=0$ & $-46,55$ & $t_{[38]}=-5,13 ; \mathrm{P}=0$ \\
A VA & 68,20 & $t_{[38]}=4,76 ; \mathrm{P}=0$ & $-24,1$ & $t_{[38]}=-4,14 ; \mathrm{P}=0$ \\
\hline \hline LimiarA VA + energia VB & 76,35 & $t_{[38]}=7,79 ; \mathrm{P}=0$ & 7,35 & $t_{[38]}=1,42 ; \mathrm{P}=0,16$ \\
LimiarS VB + energia VB & 71,10 & $t_{[38]}=8,06 ; \mathrm{P}=0$ & 6,15 & $t_{[38]}=0,95 ; \mathrm{P}=0,35$ \\
A VB + energia VA & $-76,40$ & $t_{[38]}=-3,56 ; \mathrm{P}=0$ & $-37,25$ & $t_{[38]}=-6,45 ; \mathrm{P}=0$ \\
S VA + Limiar VA & 18,90 & $t_{[38]}=1,26 ; \mathrm{P}=0,22$ & $-80,7$ & $t_{[38]}=-7,78 ; \mathrm{P}=0$ \\
\hline
\end{tabular}

Tabela 4.5: Índice que avalia a atividade exploratória e o nível de ansiedade do rato no LCE, calculado para 10 amostras de animais simulados a partir de cada um dos parâmetros explorados. Cada amostra simulava um grupo de 10 ratos.

\begin{tabular}{lll}
\hline Parâmetros & Valor médio do índice & Erro padrão \\
\hline \hline LimiarA VA & 0,3398 & 0,01 \\
Limiars VB & 0,3447 & 0,02 \\
Cabeça VA & 0,5523 & 0,02 \\
Cabeça VB & 0,7062 & 0,01 \\
\hline Energia VB & 0,3771 & 0,01 \\
Energia VA & 0,3374 & 0,01 \\
A VA & 0,2815 & 0,01 \\
\hline LimiarA VA + energia VB & 0,3511 & 0,01 \\
LimiarS VB + energia VB & 0,3659 & 0,02 \\
A VB + energia VA & 0,3511 & 0,01 \\
S VA + energia VA & 0,2631 & 0,02 \\
S VA + LimiarA VA & 0,2873 & 0,03 \\
\hline
\end{tabular}

\subsubsection{Arena}

O modelo controle para o LCE descrito na seção acima oferece padrões de comportamento dentro do esperado para o animal que é submetido à Arena em condições de controle: o organismo simulado explora e permanece por mais tempo perto das paredes (ver tabela 4.7). Os resultados obtidos com as mudanças nos parâmetros que representam os efeitos farmacológicos típicos de drogas ansiolíticas mostraram um aumento significativo de cruzamentos 
Tabela 4.6: Valor médio do índice $\pi \pm 0$ erro padrão, calculados para cada uma das 11 posições nas quais foi dividido o labirinto rebatido e para cada uma das mudanças dos parâmetros. Cada amostra representa um grupo de 10 ratos.

\begin{tabular}{|c|c|c|c|c|c|c|c|c|c|c|}
\hline 1 & 2 & 3 & 4 & 5 & 6 & 7 & 8 & 9 & 10 & 11 \\
\hline \multicolumn{11}{|c|}{ Limiar $_{A}$ VA } \\
\hline 0,01 & 0,03 & 0,02 & 0,03 & 0,05 & 0,10 & 0,14 & 0,16 & 0,17 & 0,19 & 0,10 \\
\hline $\pm 0,01$ & $\pm 0,01$ & $\pm 0,01$ & $\pm 0,01$ & $\pm 0,01$ & $\pm 0,01$ & \pm 0 & $\pm 0,01$ & $\pm 0,01$ & $\pm 0,01$ & \pm 0 \\
\hline \multicolumn{11}{|c|}{ Limiars VB } \\
\hline 0,02 & 0,03 & 0,03 & 0,03 & 0,06 & 0,11 & 0,14 & 0,15 & 0,16 & 0,18 & 0,09 \\
\hline $\pm 0,01$ & $\pm 0,01$ & \pm 0 & \pm 0 & \pm 0 & \pm 0 & \pm 0 & \pm 0 & $\pm 0,01$ & $\pm 0,01$ & $\pm 0,01$ \\
\hline \multicolumn{11}{|c|}{ Cabeça VA } \\
\hline 0,02 & 0,04 & 0,04 & 0,04 & 0,05 & 0,09 & 0,13 & 0,15 & 0,16 & 0,18 & 0,10 \\
\hline \pm 0 & $\pm 0,01$ & \pm 0 & \pm 0 & $\pm 0,01$ & $\pm 0,01$ & $\pm 0,01$ & \pm 0 & $\pm 0,01$ & $\pm 0,02$ & $\pm 0,01$ \\
\hline \multicolumn{11}{|c|}{ Cabeça VB } \\
\hline 0,03 & 0,05 & 0,04 & 0,04 & 0,06 & 0,10 & 0,13 & 0,13 & 0,15 & 0,17 & 0,09 \\
\hline \pm 0 & $\pm 0,01$ & \pm 0 & \pm 0 & $\pm 0,01$ & $\pm 0,01$ & $\pm 0,01$ & $\pm 0,01$ & $\pm 0,01$ & $\pm 0,01$ & $\pm 0,01$ \\
\hline \multicolumn{11}{|c|}{ Energia VB } \\
\hline 0,01 & 0,02 & 0,03 & 0,03 & 0,05 & 0,1 & 0,15 & 0,16 & 0,17 & 0,18 & 0,09 \\
\hline $\pm 0,01$ & $\pm 0,01$ & $\pm 0,01$ & $\pm 0,01$ & $\pm 0,01$ & \pm 0 & \pm 0 & $\pm 0,01$ & $\pm 0,01$ & $\pm 0,02$ & $\pm 0,01$ \\
\hline \multicolumn{11}{|c|}{ Energia VA } \\
\hline 0,02 & 0,05 & 0,04 & 0,04 & 0,06 & 0,10 & 0,14 & 0,15 & 0,16 & 0,17 & 0,08 \\
\hline \pm 0 & \pm 0 & \pm 0 & \pm 0 & \pm 0 & \pm 0 & \pm 0 & \pm 0 & \pm 0 & \pm 0 & \pm 0 \\
\hline \multicolumn{11}{|c|}{$A \vee A$} \\
\hline 0,06 & 0,10 & 0,08 & 0,90 & 0,10 & 0,09 & 0,08 & 0,09 & 0,11 & 0,13 & 0,07 \\
\hline \pm 0 & \pm 0 & $\pm 0,01$ & \pm 0 & $\pm 0,01$ & $\pm 0,01$ & \pm 0 & \pm 0 & \pm 0 & \pm 0 & \pm 0 \\
\hline \multicolumn{11}{|c|}{ S VA } \\
\hline 0,05 & 0,10 & 0,10 & 0,10 & 0,10 & 0,10 & 0,09 & 0,09 & 0,10 & 0,11 & 0,06 \\
\hline \pm 0 & \pm 0 & \pm 0 & $\pm 0,01$ & $\pm 0,01$ & $\pm 0,01$ & $\pm 0,01$ & \pm 0 & $\pm 0,01$ & $\pm 0,01$ & \pm 0 \\
\hline \multicolumn{11}{|c|}{ Limiar $_{A}$ VA + energia VB } \\
\hline 0,03 & 0,06 & 0,05 & 0,05 & 0,06 & 0,10 & 0,14 & 0,14 & 0,15 & 0,15 & 0,07 \\
\hline \pm 0 & \pm 0 & \pm 0 & \pm 0 & \pm 0 & \pm 0 & $\pm 0,01$ & \pm 0 & \pm 0 & \pm 0 & \pm 0 \\
\hline \multicolumn{11}{|c|}{ Limiars VB + energia VB } \\
\hline 0,02 & 0,04 & 0,03 & 0,03 & 0,05 & 0,09 & 0,13 & 0,15 & 0,17 & 0,19 & 0,10 \\
\hline \pm 0 & \pm 0 & \pm 0 & \pm 0 & \pm 0 & $\pm 0,01$ & $\pm 0,01$ & $\pm 0,01$ & $\pm 0,01$ & $\pm 0,01$ & $\pm 0,01$ \\
\hline \multicolumn{11}{|c|}{ A VB + energia VA } \\
\hline 0,02 & 0,04 & 0,04 & 0,04 & 0,06 & 0,10 & 0,14 & 0,15 & 0,16 & 0,16 & 0,08 \\
\hline \pm 0 & $\pm 0,01$ & $\pm 0,01$ & \pm 0 & \pm 0 & $\pm 0,01$ & \pm 0 & \pm 0 & \pm 0 & $\pm 0,01$ & $\pm 0,01$ \\
\hline \multicolumn{11}{|c|}{ S VA + energia VA } \\
\hline 0,06 & 0,11 & 0,10 & 0,09 & 0,10 & 0,10 & 0,09 & 0,09 & 0,10 & 0,11 & 0,06 \\
\hline \pm 0 & \pm 0 & \pm 0 & \pm 0 & \pm 0 & \pm 0 & \pm 0 & \pm 0 & \pm 0 & \pm 0 & \pm 0 \\
\hline \multicolumn{11}{|c|}{$S V A+\operatorname{Limiar}_{A} V A$} \\
\hline 0,05 & 0,10 & 0,10 & 0,09 & 0,09 & 0,10 & 0,10 & 0,10 & 0,11 & 0,11 & 0,05 \\
\hline \pm 0 & \pm 0 & \pm 0 & \pm 0 & $\pm 0,01$ & \pm 0 & \pm 0 & \pm 0 & $\pm 0,01$ & $\pm 0,01$ & \pm 0 \\
\hline
\end{tabular}



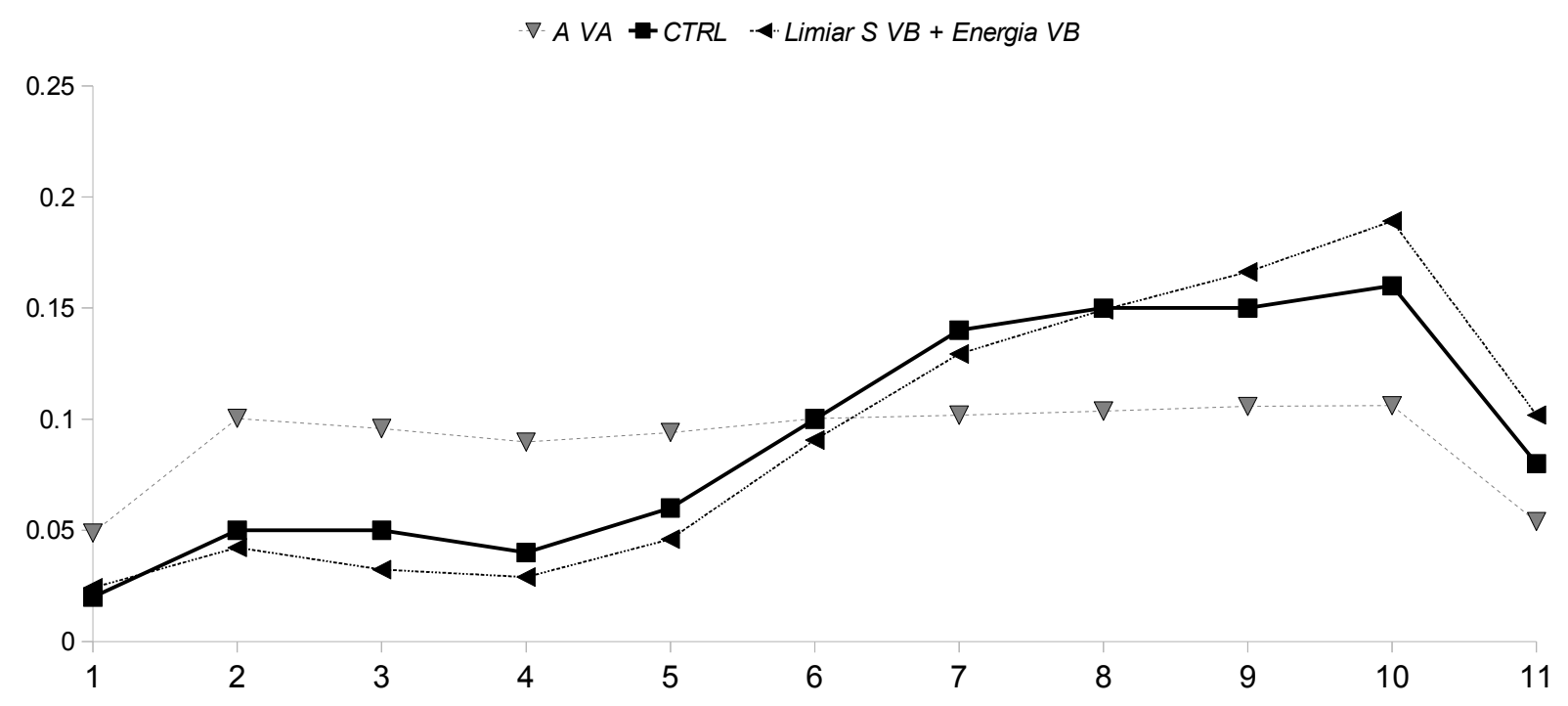

Figura 4.8: Valores de $\pi$ calculados para três simulações que representam os efeitos de drogas ansiolíticas (Esquerda VA), ansiogênicas (Limiars VB + energia VB) e um grupo controle todos submetidos ao labirinto rebatido.

$\left(t_{[38]}=-3,6706\right)$ e de tempo de permanência na área central $\left(t_{[38]}=-2,2414\right)$ (ver tabela 4.7). Porém, as mudanças nos parâmetros que representam os efeitos de drogas ansiogênicas não apresentam um padrão de diminuição dos cruzamentos $\left(t_{[38]}=-0,6531\right)$ e do tempo de permanência $\left(t_{[38]}=0,8364\right)$ na área central com respeito aos valores observados no grupo controle (ver tabela 4.7).

Já as mudanças nos parâmetros que representam drogas que aumentam a locomoção mostraram aumento significativo dos cruzamentos tanto na área central $\left(t_{[38]}=-5,077\right)$ como nas paredes $\left(t_{[38]}=-10,8041\right)$, mas sem apresentar diferenças no tempo de permanência tanto na área central $\left(t_{[38]}=-1,1217\right)$ quanto nas paredes $\left(t_{[38]}=1,1217\right)$ quando comparados com 0 grupo controle (ver tabela 4.7). Por sua vez, as mudanças nos parâmetros que simulam drogas que diminuem a locomoção apresentaram uma diminuição significativa nos cruzamentos tanto na área central $\left(t_{[38]}=6,1184\right)$ quanto nas paredes $\left(t_{[38]}=16,9359\right)$, sem apresentar diferenças no tempo de permanência na área central $\left(t_{[38]}=-1,5071\right)$ ou nas paredes $\left(t_{[38]}=1,4924\right)$ (ver tabela 4.7).

Apesar de os resultados terem sido compatíveis com os esperados para um grupo controle e para vários dos grupos que simulam os efeitos de diferentes fármacos, a morfologia da exploração do modelo de controle ajustado para o LCE dentro da Arena difere da observada em animais reais. Isso é devido ao fato de que os animais reais realizam um movimento padrão de dar várias voltas em torno das paredes da Arena. Na figura 4.9 se apresenta padrões de ratos reais submetido à Arena, registrados no Laboratório de Comportamento Exploratório da 
Tabela 4.7: Média de cruzamentos e porcentagem de tempo gasto na Arena de 20 ratos simulados sob diferentes conjuntos de parâmetros. Cada conjunto de parâmetros teve alguma modificação no parâmetro especificado na primeira coluna. As modificações podiam ser VA para valores altos do parâmetro ou VB para valores baixos.

\begin{tabular}{lllll}
\hline & \multicolumn{2}{c}{ Cruzamentos } & \multicolumn{2}{c}{ Porcentagem de tempo } \\
\hline Parâmetros modificados & Área central & Paredes & Área central & Paredes \\
\hline A VB & 39,60 & 64,15 & 0,40 & 0,60 \\
Controle & 36,35 & 57,25 & 0,39 & 0,61 \\
S VA + energia $\vee A$ & 53,65 & 62,85 & 0,47 & 0,53 \\
& & & & \\
Energia VA & 59,75 & 90,25 & 0,43 & 0,57 \\
Energia VB & 11,65 & 14,65 & 0,45 & 0,55 \\
\hline
\end{tabular}

USP de Ribeirão Preto, junto com padrões de exploração simulados. Neste ponto surge a necessidade de uma nova exploração do espaço de parâmetros na procura de modelos que façam esse tipo de exploração seguindo um padrão de círculos.

Nesta nova exploração, a função de ajuste utilizada centrou-se numa única característica, a tentativa de simular os círculos que são feitos pelo animal ao explorar a Arena caminhando perto das paredes. Para isso, as posições que se limitam com as paredes foram numeradas de 1 a 20 e se usou como função de ajuste o número máximo de posições perto da paredes que o organismo simulado visitou consecutivamente.

Com os AG foi encontrado um conjunto de parâmetros, após 230 gerações, que forneceu um ótimo ajuste aos dados experimentais. O organismo modelo, neste caso, visita em média 16 locais perto das paredes consecutivamente. Foi com o modelo para esse conjunto de parâmetros que se obteve os padrões de exploração da figura 4.10, onde se pode apreciar que o rato explora de maneira consecutiva pelo menos duas paredes da Arena, ao mesmo tempo que é possível observar que ele prefere ficar nos cantos, que é também onde mais se realizam explorações verticais.

O conjunto de parâmetros resultante desta segunda exploração com AG difere em alguns aspectos do conjunto obtido na primeira exploração. Na figura 4.11, são apresentados os valores médios e o erro padrão dos parâmetros dos melhores 10 organismos da geração 167 para o caso do ajuste ao LCE (modelo de controle para o LCE) e dos melhores 10 organismos da geração 230 para o caso da Arena. O conjunto de parâmetros obtidos para a Arena apresenta maior desvio, e valores diferentes para os parâmetros energia, $S$ e $A$. Porém, a relação entre os valores dos parâmetros permaneceu, pois os três foram deslocados proporcionalmente na vertical. 


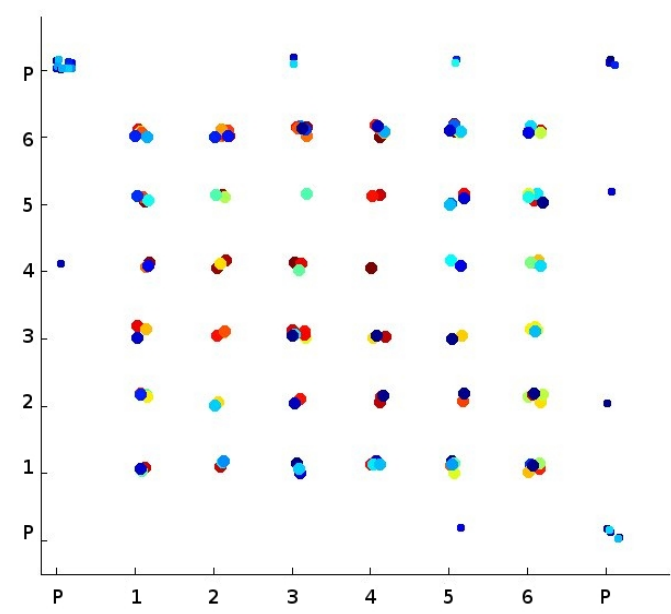

(a)

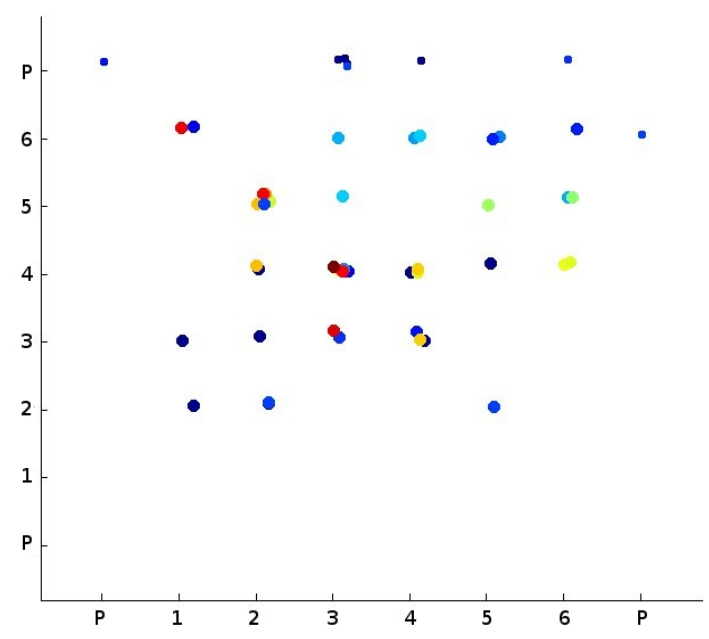

(c)

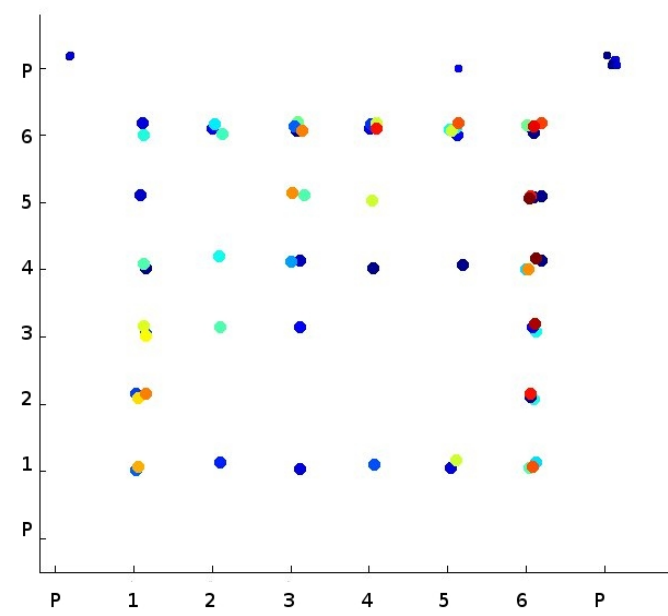

(b)

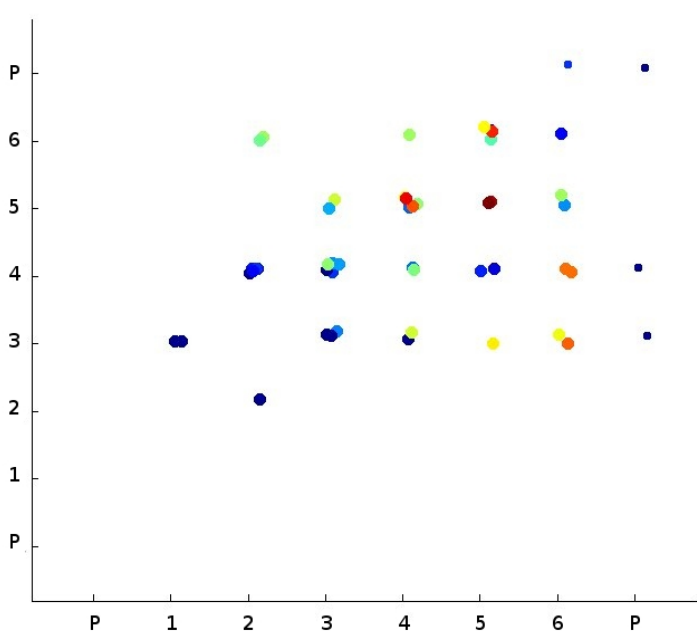

(d)

Figura 4.9: Gráficos que apresentam o padrão de exploração de animais controle reais (a e b) e simulados (c, e d) submetidos à Arena. Os números nos eixos $x$ e $y$ representam as paredes $(\mathrm{P})$ e cada um dos 6 quadrados nos quais foi dividido a Arena. Os pontos representam uma visita do animal ao respectivo quadrado ou uma exploração feita a uma parede $(\mathrm{P})$. As cores indicam o momento no qual acontecera a exploração, sendo azuis para as primeiras explorações, verde para aquelas que aconteceram na metade da sesão e vermelha para as que aconteceram no final.

\subsection{Discussão}

O modelo conexionista desenvolvido para simular o comportamento exploratório que faz um animal quando explora pela primeira vez um labirinto como o LCE ou a Arena apresentou resultados que se assemelham aos comportamentos observados em ratos reais em condições controle e sob os efeitos de diferentes fármacos. Essas semelhanças podem ser observadas tanto nos padrões das medições que resumem o comportamento dos animais no labirinto ao 


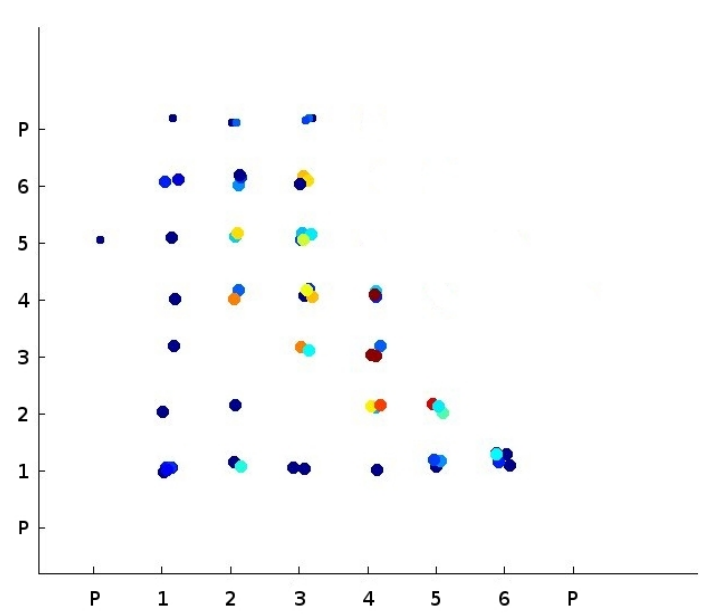

(a)

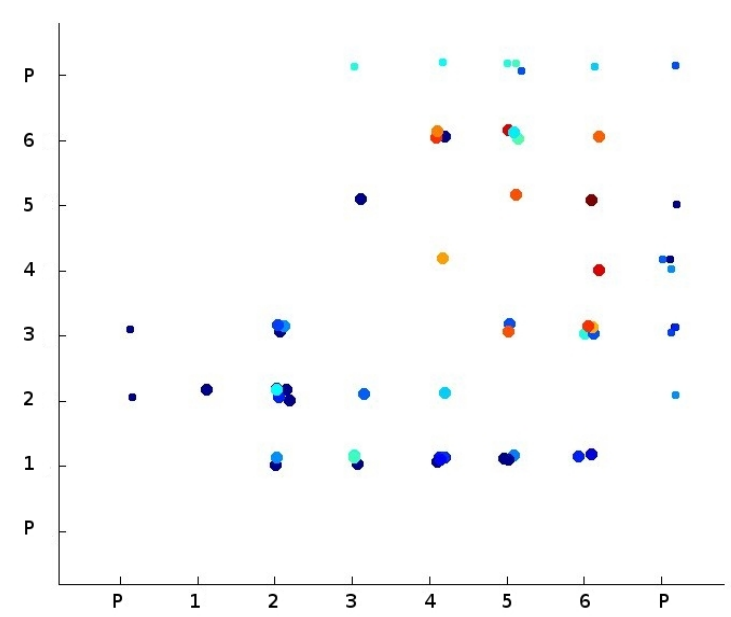

(b)

Figura 4.10: Gráficos que apresentam o padrão de exploração de organismos simulados na Arena com o conjunto de parâmetros obtido na procura da "exploração circular". Os números no eixo $x$ e $y$ representam as paredes $(P)$ e cada um dos 6 quadrados nos quais foi dividido o labirinto. Os pontos representa uma visita do animal ao respectivo quadrado ou uma exploração feita a uma parede $(\mathrm{P})$. As cores indicam o momento no qual acontecera a exploração, sendo azuis para as primeiras explorações, verde para aquelas que aconteceram na metade da sesão e vermelha para as que aconteceram no final.

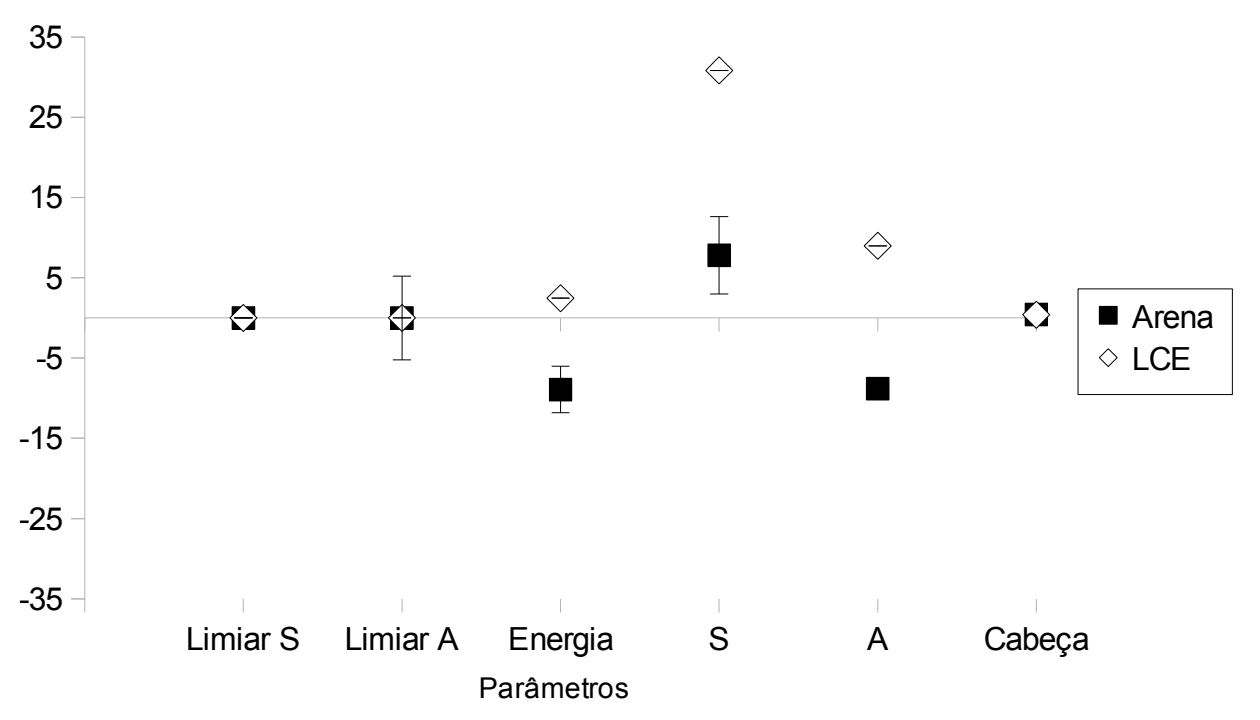

Figura 4.11: Valores dos parâmetros obtidos após a exploração com AG tendo como função de ajuste o LCE ou a Arena.

finalizar a exploração de 5 minutos (como número de cruzamentos nos diferentes locais ou tempo de permanência) quanto na morfologia do padrão de exploração (índice de exploração e matrizes de transições).

O modelo propõe um tipo de interação plausível entre as possíveis variáveis que controlam o comportamento do animal, baseado na ideia da competição de forças. Os valores finais 
usados para os parâmetros do modelo não foram obtidos de maneira arbitrária ou manual, o que poderia implicar algum tipo de viés, mas por um processo de busca no espaço de parâmetros com o uso de AG.

Os dois conjuntos de parâmetros achados, um para o LCE e o outro para a Arena, produzem comportamentos similares aos observados, sugerindo que o modelo conexionista escolhido tem condições de modelar o problema em questão. A grande similaridade entre os dois conjuntos de parâmetros, obtidos com funções de ajustes especificas para o LCE e a Arena, reafirma esta idéia, sugerindo que o modelo possui indícios de robustez que o permitem ser usado para modelar o comportamento do rato em diferentes labirintos. Como tanto a Arena como o LCE são usados para avaliar a ansiedade de animais a partir do comportamento que eles espontaneamente apresentam ao ser colocados num ambiente novo, pode-se dizer que o modelo tem condições de reproduzir o comportamento exploratório com um componente emocional. Desta maneira, ao passar do LCE para a Arena obtendo resultados consistentes, pelo menos nos indicadores que são calculados para caracterizar o comportamento do animal ao final dos 5 minutos de sessão, pode-se afirmar que o modelo é capaz de identificar a interação de forças que são comuns em ambos labirintos e que não dependem exclusivamente da organização espacial específica de um deles.

Outro aspecto interessante da utilização de AG para a exploração dos parâmetros é a emergência de padrões de comportamentos que não necessariamente constavam como condições a cumprir dentro das funções de ajuste (não mostrados). Dentre tais comportamentos foi obtido, por exemplo, um que apresentava uma maior exploração vertical dos cantos na arena, algo similar ao que animais reais apresentam (Lamprea et al., 2008).

Um aspecto que se procurou enfatizar no presente modelo é o da simulação de um componente temporal independente da locomoção. Esta é uma característica que oferece precisão ao modelo e ao mesmo tempo outorga a possibilidade de representar efeitos farmacológicos de drogas que afetam a locomoção sem afetar a preferência espacial. Este componente foi também uma peça chave no momento de se levar o modelo do LCE à Arena e de se conseguir observar possíveis efeitos farmacológicos dessa mudança. Pois sem ele seria impossível discriminar entre uma variação de um ou mais parâmetros que representem os efeitos de uma droga ansiolítica dos de uma variação que representa os efeitos de uma droga que aumenta a locomoção, devido ao fato de que para discriminar esse dois tipos de comportamentos é preciso ter estimações de dois aspectos diferentes do comportamento exploratório do animal.

O modelo revelou-se especialmente versátil no caso da simulação dos efeitos farmacológicos, devido ao fato de conseguir simular os efeitos de drogas ansiogênicas, ansiolíticas 
e daquelas que afetam a locomoção. Em alguns casos foi inclusive possível simular esses efeitos através da modificação isolada de diferentes parâmetros. Por exemplo, os efeitos de drogas ansiogênicas podem ser reproduzidos diminuindo o valor do parâmetro limiars, o que se interpreta como facilitando a escolha por locais que se encontrem nessa direção; também é possível reproduzir tais efeitos aumentando-se o valor do parâmetro limiara, o que se interpreta como diminuindo a preferência pelos locais que se encontrem nessa direção dificultando sua escolha. Essa versatilidade na maneira como são representados os efeitos de drogas pode ser considerada como outro ponto positivo do modelo. Com ele é possível reproduzir a condição na qual duas drogas diferentes, interagindo em locais diferentes, produzem os mesmos efeitos.

São também de destaque os parâmetros que possuem a capacidade de provocar um comportamento bidirecional, produzindo padrões de comportamento opostos com valores opostos, como é o caso do parâmetro energia. Este parâmetro é de especial atenção devido a que mudanças isoladas nele são capazes de reproduzir os efeitos de drogas que alteram a locomoção do animal sem por isso mudar a preferência do organismo por locais seguros. É um parâmetro que ao interagir com os dois canais do sistema emocional é capaz de aumentar ou diminuir o número de decisões que o sistema toma durante uma sessão, provocando aumento ou diminuição do número de passos que o animal faz.

É importante ressaltar que, para os dois labirintos, foi possível reproduzir o comportamento em condições de controle e sob efeito de fármacos ansiolíticos e que aumentam ou diminuem a locomoção do organismo. O fato de não se conseguir reproduzir o comportamento que se observa na Arena quando os animais são submetidos a drogas ansiogênicas pode ser um aspecto que diferencie as explorações feitas nos dois labirintos.

Uma possível razão que explique a não reprodução do padrão de exploração sob efeito de drogas ansiogênicas na Arena pode ser o fato de que o organismo dentro da Arena conta com mais possibilidades de escolha no momento de decidir a direção do próximo passo. Por exemplo, é possível que o organismo que explora a Arena submetido a drogas ansiogênicas faça um percurso perto das paredes, mas não necessariamente caminhando sempre nas posições limítrofes a elas. Em um tal caso, o organismo não apresentaria um padrão de deslocamento tão claro como o que é encontrado no LCE para esse tipo de drogas.

Por último, um outro aspecto a destacar é a maneira como foram definidas as motivações que interagem no modelo, pois não necessariamente têm que ser interpretadas como duas motivações de natureza diferente. Em outras palavras, as motivações podem ser consideradas não somente como uma motivação positiva confrontada com uma negativa, como no caso de, 
ou explorar um ambiente novo, ou se proteger. É possível também definir as motivações como duas motivações negativas que são confrontadas, por exemplo, fugir ou evitar. Estas são duas motivações similares, porém capaz de gerar comportamentos opostos. Isto não é necessariamente algo fora de contexto, já que, por exemplo, poder-se-ía considerar que quando o animal vai em direção aos braços abertos $(A)$ ele está procurando por onde fugir, e quando ele vai na direção contraria $(S)$ ele está procurando onde se esconder. 


\section{Conclusões finais}

No presente trabalho se fez uso de diferentes ferramentas vindas da modelagem matemática e computacional para tentar ampliar o conhecimento sobre o comportamento do rato quando submetido ao LCE. Inicialmente, trabalhou-se no sentido de tentar identificar regularidades no comportamento do rato que possam ser utilizadas para caracterizá-lo. Procurou-se por índices ou medidas que ofereçam informação sobre o que está acontecendo ao longo da trajetória do rato dentro do labirinto, e não somente sobre o que acontece ao redor do seu centro.

Trabalhou-se com as medidas que oferecem maior objetividade no momento de ser registradas: tempo de permanência e deslocamentos. Elas foram registradas considerando-se, além do local onde aconteceram, a direção de onde o rato estava vindo. A partir dessa combinação entre frequência e direção foi possível ampliar a resolução dos detalhes que comumente são observados no LCE. Porém, o aumento da resolução envolve também o aumento de variabilidade nos dados. Essa dificuldade foi contornada usando-se a representação rebatida do labirinto, na qual ele foi considerado, para efeitos de modelagem e caracterização estatística, como contendo apenas um braço aberto e outro fechado.

A análise das informações coletadas permitiu achar regularidades nos deslocamentos que foram avaliadas por meio de gráficos de frequência de transições versus ranking e levaram à estimação das probabilidades de o rato se deslocar numa determinada direção a partir de um dado ponto. Essas duas abordagens ofereceram informação acerca das preferências do animal dentro do LCE e como elas são afetadas pelos efeitos de drogas. Neste sentido, consolidou-se neste trabalho três medidas que podem ser utilizadas para identificar diferenças entre fármacos, através de índices numéricos capazes de capturar detalhes do que acontece no interior dos braços. Por exemplo, o índice de atividade exploratória possui a capacidade de resumir em um número a relação entre exploração e ansiedade. Da mesma maneira, as matrizes de transição permitem identificar para onde é mais provável que o rato transite quando se encontra num determinado local e os vetores de valores de $\pi$ permitem predizer onde poderia ser mais provável achar o rato ao longo da sessão. Estas medidas 
se apresentaram especialmente úteis para avaliar o desempenho do modelo computacional, permitindo melhorar seus ajustes e sua capacidade para reproduzir os efeitos das drogas.

A sensibilidade aos efeitos das drogas por parte dessas medidas varia, e isso é importante para ajudar a caracterizar os efeitos dessas drogas. Por exemplo, usando matrizes de transição é possível identificar facilmente uma droga ansiolítica, porém as diferenças entre um animal sob efeito de drogas ansiogênicas e um do grupo controle são mais sutis. Apesar disso, é possível que os índices para caracterizar o comportamento do rato no LCE propostos aqui se mostrem úteis em estudos com outro tipo de drogas diferentes das ansiolíticas e ansiogênicas que foram testadas. Espera-se também que, devido ao fato de que as medidas propostas são calculadas a partir dos deslocamentos, elas possam ser facilmente incorporadas em software de registro.

O cálculo das matrizes de transição ofereceu, além dos padrões de exploração que descrevem cada condição farmacológica, a possibilidade de construir um modelo computacional. Essa possibilidade surgiu depois de se calcular as matrizes de transição e se observar que elas acompanhavam as mudanças dos fármacos. Porém, apesar do ajuste que o modelo de cadeias de Markov apresentava, decidiu-se avaliar modelos de ordem superior numa tentativa de estimar de quanta informação o rato precisa para tomar uma decisão. Para isso, operacionalizou-se o conceito de quantidade de informação como o número de passos numa trajetória que condicionam uma decisão. Desta maneira, se a probabilidade de o rato se deslocar numa determinada direção dependesse de, por exemplo, as três últimas posições que ele visitou, a quantidade de informação que o rato utiliza seria maior do que se essa probabilidade dependesse somente da última posição.

Ao analisar os resultados, não se encontrou informação suficiente para afirmar que para calcular as probabilidades de transição é necessário contar com mais informação do que a da posição atual. Este é um resultado interessante que permite afirmar que o animal explora o labirinto sem seguir uma trajetória claramente definida, o que pode se dever ao fato de que o animal dentro do LCE não tem que cumprir uma determinada tarefa que oriente a maneira como ele deve explorar e, por conseguinte, condicione uma determinada trajetória. Este fato é comum para qualquer exposição inicial na qual os animais exploram de maneira desprevenida um determinado local, razão pela qual seria possível usar modelos de cadeias de Markov para estudar os padrões de exploração de labirintos como o LCE e a Arena e como eles são afetados por fármacos.

Indo um passo além da caracterização do padrão de exploração, o capítulo 4 apresenta um modelo baseado em competição de forças com parâmetros selecionados por AG para reproduzir 
o comportamento do animal. A abordagem adotada condiciona a maneira como essas forças interagem, porém não condiciona os valores que elas podem tomar. Isto permitiu que os parâmetros do modelo se ajustassem ao problema, chegando inclusive a mudar a maneira como as forças interagem, pois num dado momento um determinado parâmetro assumiu o valor 0 , anulando com isso o efeito de uma determinada força.

O modelo do capítulo 4 também foi utilizado para identificar possíveis pontos de ação de drogas, procurando por parâmetros mais sensíveis a essas ações. Um grande número de combinações de parâmetros dentro de determinadas faixas de valores foram testadas para se estudar o efeito de drogas. Este tipo de análise deixa aberta a possibilidade de se achar novas interações entre fármacos ou de prever efeitos de fármacos ainda não estudados no LCE. Da mesma maneira, pelo fato de ter trabalhado com um modelo conexionista, fica aberta a possibilidade de estabelecer relações entre os componentes do modelo e estruturas ou mecanismos cerebrais. Neste sentido, um possível passo a seguir seria relacionar as unidades da rede com estruturas cerebrais como a Substância Cinzenta Periaquedutal, a amígdala e o cortex pré-frontal, todas elas relacionadas com os sistemas de defesa do organismo (McNaughton e Corr, 2004), para o qual pode ser necessário a inclussão de mais comportamentos além do deslocamento do animal.

Seguindo com a ideia de flexibilidade que tem caracterizado a construção de modelos conexionistas para o comportamento do rato no $L C E$, as variáveis que definem a estrutura do labirinto podem assumir diferentes valores e com isso se pode conseguir representar um labirinto diferente. Este foi o caso para a Arena. O fato de se ter encontrado resultados similares para ambos os labirintos sugere que o modelo pode ser considerado como um modelo de exploração com um componente emocional sem necessariamente ficar circunscrito a um labirinto específico. Isto fortalece a ideia de que em ambos os labirintos há mecanismos subjacentes ao comportamento em comum, e que as drogas interagem de maneira similar com esses mecanismos.

Finalmente, pode-se afirmar que todas as diferentes ferramentas de modelagem matemática e computacional usadas nesta tese ofereceram informação acurada sobre o comportamento do rato no LCE. Informação que está expressa em termos de índices ou de equações, permitindo sua fácil reprodução. Espera-se que este tipo de informação seja de utilidade para os diferentes grupos de pesquisa que trabalham na área, tanto a nível teórico a partir das questões levantadas pelos modelos, quanto a nível prático na utilização dos índices de atividade exploratória aqui propostos. Espera-se também, que todas estas questões ajudem na construção de novos modelos que ajudem na comprensão do comportamento exploratório. 


\section{APÊNDICE $A-$ Cálculo do índice de atividade exploratória}

O seguinte código apresenta a maneira de calcular o índice de atividade exploratória fazendo uso das funções de ajuste de Matlab, supondo que as frequências de transições estão armazenadas em um vetor chamado $T$ o valor do índice de atividade exploratório seria armazenado na variável $k$.

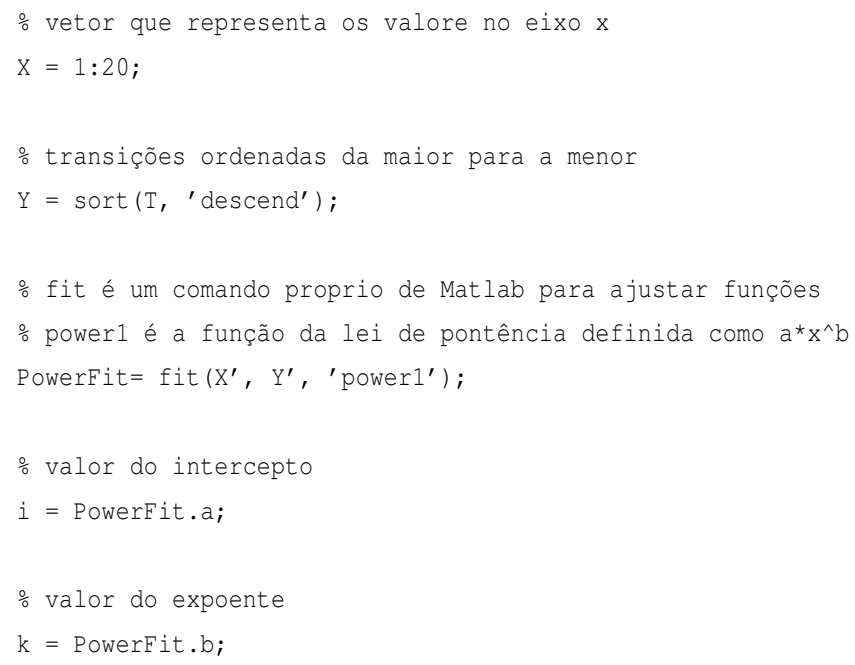




\section{APÊNDICE B - Cálculo dos vetores de valores de $\pi$}

Os vetores de valores de $\pi$ podem ser calculados de duas maneiras: solucionando o sistema de equações ou multiplicando as matrizes estocásticas por elas mesmas iteradamente um número determinado de vezes. A seguir, são apresentados dois segmentos de código de Matlab para calcular os valores de $\pi$ de uma ou outra maneira.

\section{B.1 Cálculo solucionando o sistema de equações}

As duas equações que são utilizadas surgem da definição dos valores de $\pi$ :

$$
\begin{aligned}
\pi & =\pi \mathbb{P}, \\
\sum_{i=1}^{11} \pi_{i} & =1 .
\end{aligned}
$$

O seguinte código para Matlab resolve essas equações e obtém os valores de $\pi$, partindo de uma matriz estocástica denominada $P$ com dimensões $11 \times 11$, dando como resultado um vetor fila de 11 elementos chamado $P i$, na notação de Matlab o valor $\pi_{1}=P(1)$, o valor $\pi_{2}=P(2)$ e assim respectivamente.

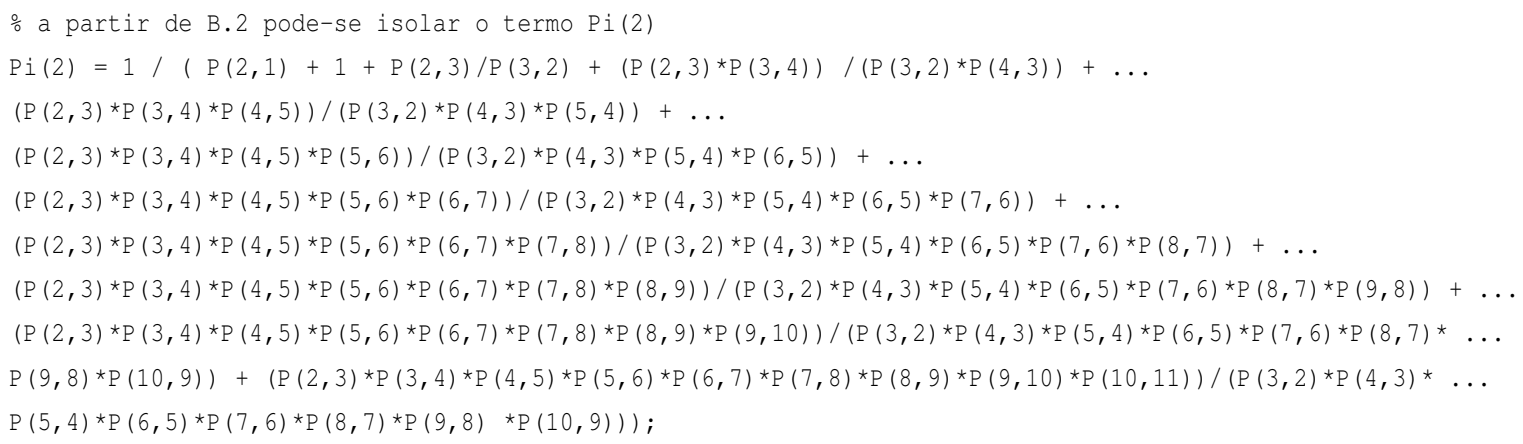




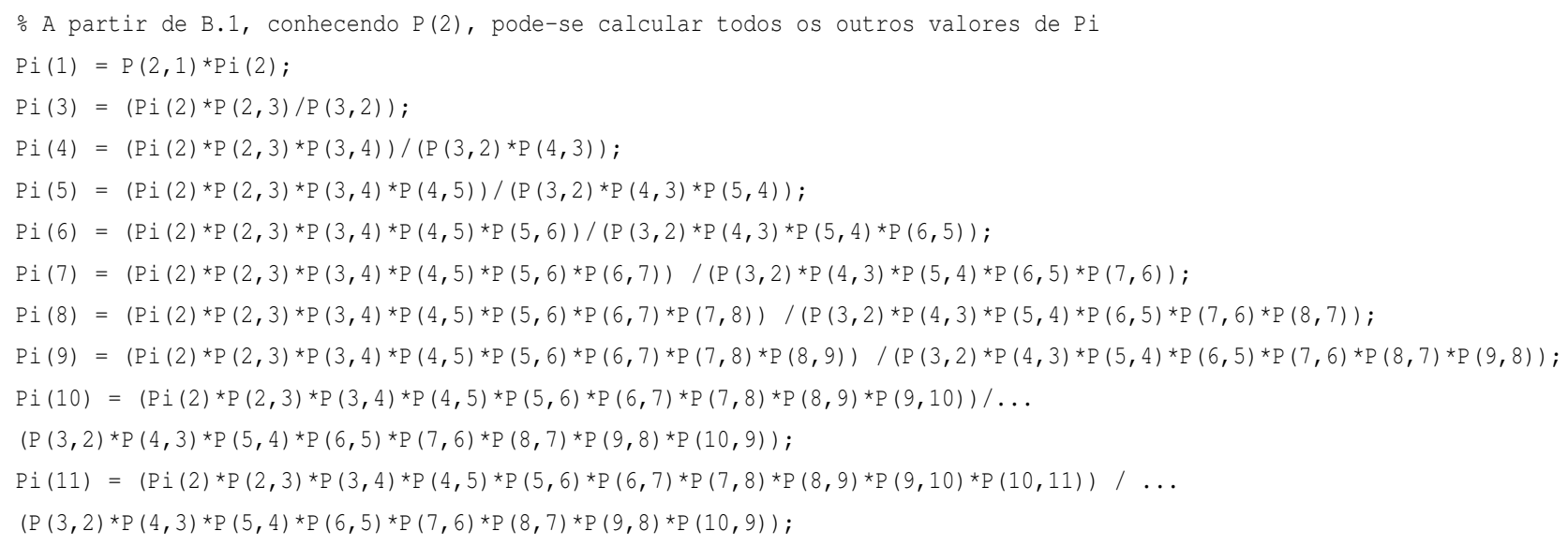

\section{B.2 Cálculo multiplicando a matriz estocástica}

Os valores de $\pi$ também podem ser estimados multiplicando as matrizes estocásticas por elas mesmas iteradamente um número determinado de vezes

$$
\mathbb{P}^{n}=\mathbb{P} \times \mathbb{P} \times \mathbb{P} \times \mathbb{P} \times \ldots \times \mathbb{P}
$$

obtendo os valores de $\pi$ em cada uma das linhas da matriz resultante. Porém, dada a caraterística da matriz estocástica do LCE (ver Figura 3.3) de possuir valores somente em duas diagonais, a multiplicação gera matrizes com zeros intercalados periodicamente como é apresentado na figura B.1. Devido a isso, para o cálculo dos valores de $\pi$ é preciso multiplicar $n$ e $n+1$ vezes a matriz estocástica, somar as linhas de essas duas matrizes e dividir entre dois. No seguinte código para Matlab é apresentado o procedimento, no qual a matriz estocástica (de $11 \times 11$ ) é novamente denominada por $P$ dando como resultado um vetor fila de 11 elementos chamado $P i$.

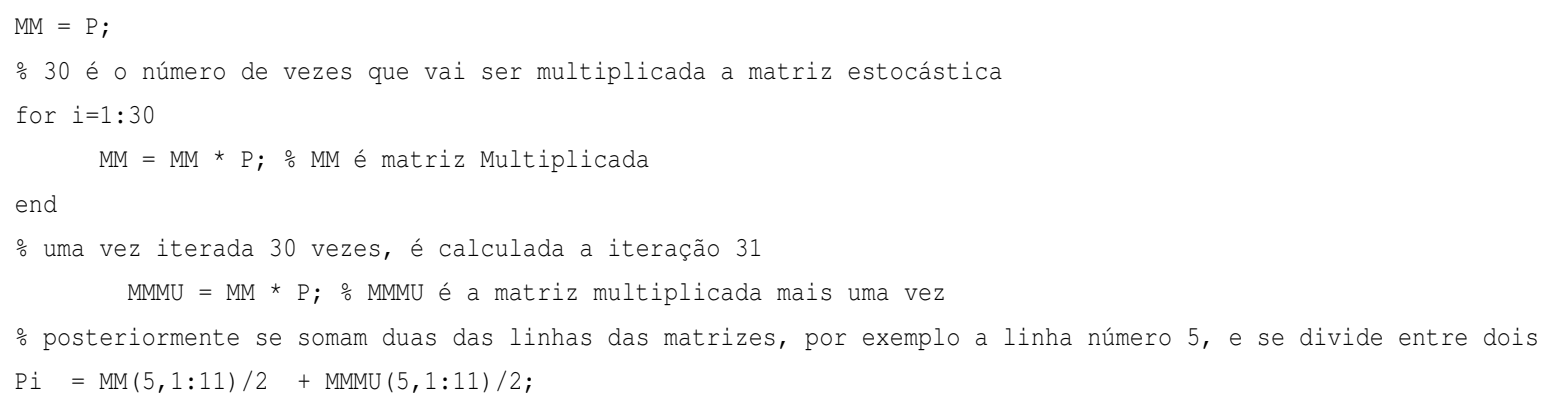

Ao comparar os resultados obtidos com ambos métodos, podemos dizer que após multiplicar 30 vezes a matriz estocástica os valores de $\pi$ obtidos se aproximam muito bem aos valores 


$$
\mathbb{P} \times \mathbb{P}=\left(\begin{array}{ccccccccccc}
0 & \pi_{2} & 0 & \pi_{4} & 0 & \pi_{6} & 0 & \pi_{8} & 0 & \pi_{10} & 0 \\
\pi_{1} & 0 & \pi_{3} & 0 & \pi_{5} & 0 & \pi_{7} & 0 & \pi_{9} & 0 & \pi_{11} \\
0 & \pi_{2} & 0 & \pi_{4} & 0 & \pi_{6} & 0 & \pi_{8} & 0 & \pi_{10} & 0 \\
\pi_{1} & 0 & \pi_{3} & 0 & \pi_{5} & 0 & \pi_{7} & 0 & \pi_{9} & 0 & \pi_{11} \\
0 & \pi_{2} & 0 & \pi_{4} & 0 & \pi_{6} & 0 & \pi_{8} & 0 & \pi_{10} & 0 \\
\pi_{1} & 0 & \pi_{3} & 0 & \pi_{5} & 0 & \pi_{7} & 0 & \pi_{9} & 0 & \pi_{11} \\
0 & \pi_{2} & 0 & \pi_{4} & 0 & \pi_{6} & 0 & \pi_{8} & 0 & \pi_{10} & 0 \\
\pi_{1} & 0 & \pi_{3} & 0 & \pi_{5} & 0 & \pi_{7} & 0 & \pi_{9} & 0 & \pi_{11} \\
0 & \pi_{2} & 0 & \pi_{4} & 0 & \pi_{6} & 0 & \pi_{8} & 0 & \pi_{10} & 0 \\
\pi_{1} & 0 & \pi_{3} & 0 & \pi_{5} & 0 & \pi_{7} & 0 & \pi_{9} & 0 & \pi_{11} \\
0 & \pi_{2} & 0 & \pi_{4} & 0 & \pi_{6} & 0 & \pi_{8} & 0 & \pi_{10} & 0
\end{array}\right)
$$

(a)

$$
\mathbb{P} \times \mathbb{P} \times \mathbb{P}=\left(\begin{array}{ccccccccccc}
\pi_{1} & 0 & \pi_{3} & 0 & \pi_{5} & 0 & \pi_{7} & 0 & \pi_{9} & 0 & \pi_{11} \\
0 & \pi_{2} & 0 & \pi_{4} & 0 & \pi_{6} & 0 & \pi_{8} & 0 & \pi_{10} & 0 \\
\pi_{1} & 0 & \pi_{3} & 0 & \pi_{5} & 0 & \pi_{7} & 0 & \pi_{9} & 0 & \pi_{11} \\
0 & \pi_{2} & 0 & \pi_{4} & 0 & \pi_{6} & 0 & \pi_{8} & 0 & \pi_{10} & 0 \\
\pi_{1} & 0 & \pi_{3} & 0 & \pi_{5} & 0 & \pi_{7} & 0 & \pi_{9} & 0 & \pi_{11} \\
0 & \pi_{2} & 0 & \pi_{4} & 0 & \pi_{6} & 0 & \pi_{8} & 0 & \pi_{10} & 0 \\
\pi_{1} & 0 & \pi_{3} & 0 & \pi_{5} & 0 & \pi_{7} & 0 & \pi_{9} & 0 & \pi_{11} \\
0 & \pi_{2} & 0 & \pi_{4} & 0 & \pi_{6} & 0 & \pi_{8} & 0 & \pi_{10} & 0 \\
\pi_{1} & 0 & \pi_{3} & 0 & \pi_{5} & 0 & \pi_{7} & 0 & \pi_{9} & 0 & \pi_{11} \\
0 & \pi_{2} & 0 & \pi_{4} & 0 & \pi_{6} & 0 & \pi_{8} & 0 & \pi_{10} & 0 \\
\pi_{1} & 0 & \pi_{3} & 0 & \pi_{5} & 0 & \pi_{7} & 0 & \pi_{9} & 0 & \pi_{11}
\end{array}\right)
$$

(b)

Figura B.1: Resultado da multiplicação da matriz estocástica em (a) um número par de vezes e em (b) um número ímpar.

de $\pi$ calculados solucionando as equações para qualquer dos grupos estudados. Razão pela qual sugerimos 30 iterações para o cálculo dos valores de $\pi$. 


\section{APÊNDICE C - Relação dos valores dos parâmetros usados no modelo do LCE e da Arena}

Tabela C.1: Relação dos valores dos parâmetros achados com AG para o modelo do LCE e da Arena

\begin{tabular}{|l|r|r|}
\hline Nome do Parâmetro & LCE & Arena \\
\hline$s_{i}$ & 30,2003 & $-1,8312$ \\
$a_{i}$ & 15,2612 & $-5,7349$ \\
Limiars & 0,0016 & 0,0052 \\
LimiarA & $-0,0011$ & $-0,0025$ \\
$o$ & 52,4436 & 5,9390 \\
$b$ & 14,5673 & 6,3430 \\
$c$ & 0,8747 & 6,1621 \\
$k$ & 12,1449 & 4,0207 \\
$r$ & 0,6237 & 4,5653 \\
$n$ & 1,9119 & 4,5656 \\
$p$ & 13,1084 & 12,0756 \\
$q$ & 11,8671 & 7,8122 \\
Energia & 2,4573 & $-8,9202$ \\
S & 30,8412 & 7,8087 \\
A & 8,9860 & $-8,8215$ \\
Cabeça & 0,4100 & 0,4140 \\
\hline
\end{tabular}




\section{Referências}

AKAIKE, H. A new look at the statistical model identification. Automatic Control, IEEE Transactions on, v. 19, n. 6, p. 716-723, Dec 1974. ISSN 0018-9286. Disponível em: $<$ http://ieeexplore.ieee.org/stamp/stamp.jsp?tp=Earnumber $=1100705>$.

ANSELONI, V. Z.; BRANDÃO, M. L. Ethopharmacological analysis of behaviour of rats using variations of the elevated plus-maze. Behav Pharmacol, Laboratório de Psicobiologia, FFCLRP, Ribeirão Preto, SP, Brasil., v. 8, n. 6-7, p. 533-40, Nov 1997. ISSN 0955-8810. Disponível em: <http://view.ncbi.nlm.nih.gov/pubmed/9832967>.

BELZUNG, C.; GRIEBEL, G. Measuring normal and pathological anxiety-like behaviour in mice: a review. Behavioural Brain Research, v. 125, n. 1-2, p. 141-149, 2001. ISSN 0166-4328. Disponível em: <http://www.sciencedirect.com/science/article/B6SYP_448YK1KP/2/38f82bf637492d0e4e5475fb3728d33a> .

BERTOGLIO, L. J.; CAROBREZ, A. P. Behavioral profile of rats submitted to session 1-session 2 in the elevated plus-maze during diurnal/nocturnal phases and under different illumination conditions. Behav Brain Res, v. 132, n. 2, p. 135-43, maio 2002. ISSN 0166-4328. Disponível em: <http://www.ncbi.nlm.nih.gov/pubmed/11997144>.

BEVINGTON, P. R.; ROBINSON, D. K. Data Reduction and Error Analysis for The Physical Sciences. Subsequent. [S.l.]: McGraw-Hill Companies, 1992. ISBN 0079112439.

CARDENAS, F.; LAMPREA, M. R.; MORATO, S. Vibrissal sense is not the main sensory modality in rat exploratory behavior in the elevated plus-maze. Behav Brain Res, v. 122, n. 2, p. 169-74, ago. 2001. ISSN 0166-4328. Disponível em: <http://www.ncbi.nlm.nih.gov/pubmed/11334647>.

CAROBREZ, A. P.; BERTOGLIO, L. J. Ethological and temporal analyses of anxiety-like behavior: the elevated plus-maze model 20 years on. Neuroscience and Biobehavioral Reviews, v. 29, n. 8, p. 1193-1205, 2005. ISSN 0149-7634. Disponível em: <http://www.ncbi.nlm.nih.gov/pubmed/16084592>.

CAROLA, V. et al. Evaluation of the elevated plus-maze and open-field tests for the assessment of anxiety-related behaviour in inbred mice. Behavioural Brain Research, v. 134, n. 1-2, p. 49-57, ago. 2002. ISSN 0166-4328. Disponível em: <http://www.sciencedirect.com/science/article/B6SYP-44N047M-1/2/08a9c103df5370103529cd2260fd1314>.

CHEN, S. H.; JAKEMAN, A. J.; NORTON, J. P. Artificial intelligence techniques: An introduction to their use for modelling environmental systems. Math. Comput. Simul., v. 78, n. 2-3, p. 379-400, 2008. ISSN 0378-4754. Disponível em: <http://www.sciencedirect.com/science/article/B6V0T-4RMNYGW-3/2/1f4fc2378bec695f3c2b478776e674d9>. 
CRUZ, A. P.; FREI, F.; GRAEFF, F. G. Ethopharmacological analysis of rat behavior on the elevated plus-maze. Pharmacol Biochem Behav, v. 49, n. 1, p. 171-6, Sep 1994. ISSN 0091-3057. Disponível em: <http://view.ncbi.nlm.nih.gov/pubmed/7816869>.

DAWSON, G. R.; TRICKLEBANK, M. D. Use of the elevated plus maze in the search for novel anxiolytic agents. Trends Pharmacol Sci, v. 16, n. 2, p. 33-6, fev. 1995. ISSN 0165-6147. Disponível em: <http://www.ncbi.nlm.nih.gov/pubmed/7762079>.

DIESTEL, R. Graph theory, volume 173 of Graduate Texts in Mathematics. Heidelberg: Springer-Verlag, 2005. 92 p. ISSN 3540261834.

FRUSSA-FILHO, R.; RIBEIRO, R. de A. One-trial tolerance to the effects of chlordiazepoxide in the elevated plus-maze is not due to acquisition of a phobic avoidance of open arms during initial exposure. Life Sciences, v. 71, n. 5, p. 519-525, jun. 2002. ISSN 0024-3205. Disponível em: <http://www.sciencedirect.com/science/article/B6T99-45PK7G5-4/2/d86a9fdc8c82613b792582fb83caf0d5>.

GARCIA, A. M. B.; CARDENAS, F. P.; MORATO, S. Effect of different illumination levels on rat behavior in the elevated plus-maze. Physiol Behav, v. 85, n. 3, p. 265-70, jun. 2005. ISSN 0031-9384. Disponível em: <http://www.ncbi.nlm.nih.gov/pubmed/15927214>.

GIDDINGS, J. M. Modeling the Behavior of Rats in an Elevated Plus-Maze. Dissertação (Mestrado) - Acadia University, 2002. Disponível em: <http://www.cs.usask.ca/faculty/spiteri/students/jgiddings_bsc_thesis.pdf>. Acesso em: 1 abr. 2010.

GILAT, A.; SUBRAMANIAM, V. Métodos Numéricos para Engenheiros e Cientistas. Artmed. [S.l.: s.n.], 2000. ISBN 9788577802050.

GROSSBERG, S. How does a brain build a cognitive code? Psychol Rev, v. 87, n. 1, p. 1-51, Jan 1980. ISSN 0033-295X. Disponível em: <http://view.ncbi.nlm.nih.gov/pubmed/7375607>.

GUTTORP, P. Stochastic modeling of scientific data. [S.L.]: Chapman \& Hall/CRC, 1995. ISSN 0412992817.

HANDLEY, S. L.; MITHANI, S. Effects of alpha-adrenoceptor agonists and antagonists in a maze-exploration model of 'fear'-motivated behaviour. Naunyn Schmiedebergs Arch Pharmacol, v. 327, n. 1, p. 1-5, ago. 1984. ISSN 0028-1298. Disponível em: <http://www.ncbi.nlm.nih.gov/pubmed/6149466>.

HAYKIN, S. Neural Networks and Learning Machines. 3. ed. [S.l.]: Prentice Hall, 2008. ISBN 0131471392.

HOLMES, A.; RODGERS, R. J. Responses of swiss-webster mice to repeated plus-maze experience: further evidence for a qualitative shift in emotional state? Pharmacol Biochem Behav, v. 60, n. 2, p. 473-88, jun. 1998. ISSN 0091-3057. Disponível em: <http://www.ncbi.nlm.nih.gov/pubmed/9632231>.

KEMENY, J.; SNELL, J. Finite markov chains. NJ: Springer, 1976. ISSN 0-387-90192-2.

KLIETHERMES, C.; FINN, D.; CRABBE, J. Validation of a modified mirrored chamber sensitive to anxiolytics and anxiogenics in mice. Psychopharmacology, Springer, v. 169, n. 2, p. 190-197, 2003. ISSN 0033-3158. Disponível em: <http://www.ncbi.nlm.nih.gov/pubmed$112783153>$. 
LAMPREA, M. R. et al. Thigmotactic responses in an open-field. Braz J Med Biol Res, v. 41, n. 2, p. 135-40, fev. 2008. ISSN 1414-431X. Disponível em: < http://www.ncbi.nlm.nih.gov/pubmed/18297193>.

LISTER, R. G. Ethologically-based animal models of anxiety disorders. Pharmacol Ther, v. 46, n. 3, p. 321-40, 1990. ISSN 0163-7258. Disponível em: <http://www.ncbi.nlm.nih.gov/pubmed/2188266>.

MCNAUGHTON, N.; CORR, P. J. A two-dimensional neuropsychology of defense: fear/anxiety and defensive distance. Neurosci Biobehav Rev, v. 28, n. 3, p. 285-305, May 2004. ISSN 0149-7634. Disponível em: < http://view.ncbi.nlm.nih.gov/pubmed/15225972>.

MIRANDA, D. et al. Modelado del comportamiento de ratas en laberinto en cruz elevado basado en redes neuronales artificiales. Revista Colombiana de Física, v. 41, n. 2, p. 406-408, 2009. ISSN 0120-2650. Disponível em: <http://revcolfis.org/publicaciones/vol41erline 2.htm>.

MITCHELL, M. An Introduction to Genetic Algorithms. [S.L.]: The MIT Press:London, 1999. ISSN 0262631857.

MONTGOMERY, K. C. The relation between fear induced by novel stimulation and exploratory behavior. J Comp Physiol Psychol, v. 48, n. 4, p. 254-60, Aug 1955. ISSN 0021-9940. Disponível em: <http://view.ncbi.nlm.nih.gov/pubmed/13252152>.

MORATO, S. O papel da visão na aversão aos espaços abertos no labirinto em cruz elevado. Psicologia USP, v. 17, n. 4, p. 159-174, 2006. ISSN 0103-6564.

PEARSON, K. The problem of the random walk. Nature, v. 72 , n. 1865, p. 294, 1905. ISSN 0028-0836. Disponível em: <http://www.nature.com/nature/journal/v72/n1865/abs/072294b0.html>.

PELLOW, S. et al. Validation of open:closed arm entries in an elevated plus-maze as a measure of anxiety in the rat. J Neurosci Methods, v. 14, n. 3, p. 149-67, Aug 1985. ISSN 0165-0270. Disponível em: <http://view.ncbi.nlm.nih.gov/pubmed/2864480>.

PELLOW, S.; FILE, S. E. Anxiolytic and anxiogenic drug effects on exploratory activity in an elevated plus-maze: a novel test of anxiety in the rat. Pharmacol Biochem Behav, v. 24, n. 3, p. 525-9, Mar 1986. ISSN 0091-3057. Disponível em: < http://view.ncbi.nlm.nih.gov/pubmed$12871560>$.

PRUT, L.; BELZUNG, C. The open field as a paradigm to measure the effects of drugs on anxiety-like behaviors: a review. fev. 2003. 3-33 p. Disponível em: < http://www.ncbi.nlm.nih.gov/pubmed/12600700>.

RAMOS, A. Animal models of anxiety: do i need multiple tests? Trends Pharmacol Sci, v. 29, n. 10, p. 493-8, out. 2008. ISSN 0165-6147. Disponível em: <http://www.ncbi.nlm.nih.gov/pubmed/18755516>.

RAMOS, A. et al. A genetic and multifactorial analysis of anxiety-related behaviours in lewis and shr intercrosses. Behav Brain Res, v. 96, n. 1-2, p. 195-205, nov. 1998. ISSN 0166-4328. 
RAMOS, A. et al. Integrating the open field, elevated plus maze and light/dark box to assess different types of emotional behaviors in one single trial. Behav Brain Res, v. 193, n. 2, p. 277-88, nov. 2008. ISSN 0166-4328. Disponível em: <http://www.ncbi.nlm.nih.gov/pubmed/18590774>.

RODGERS, R. J. et al. Animal models of anxiety: an ethological perspective. Braz J Med Biol Res, v. 30, n. 3, p. 289-304, mar. 1997. ISSN 0100-879X. Disponível em: $<$ http://www.ncbi.nlm.nih.gov/pubmed/9246227>.

RODGERS, R. J.; JOHNSON, N. J. Factor analysis of spatiotemporal and ethological measures in the murine elevated plus-maze test of anxiety. Pharmacol Biochem Behav, Department of Psychology, University of Leeds, UK., v. 52, n. 2, p. 297-303, Oct 1995. ISSN 0091-3057. Disponível em: <http://view.ncbi.nlm.nih.gov/pubmed/8577794>.

RODGERS, R. J.; JOHNSON, N. J. Behaviorally selective effects of neuroactive steroids on plus-maze anxiety in mice. Pharmacol Biochem Behav, Ethopharmacology Laboratory, School of Psychology, University of Leeds, UK., v. 59, n. 1, p. 221-32, Jan 1998. ISSN 0091-3057. Disponível em: <http://www.ncbi.nlm.nih.gov/pubmed/9443559>.

ROSA, V. P. et al. Temporal analysis of the rat's behavior in the plus-maze: effect of midazolam. Pharmacol Biochem Behav, v. 67, n. 1, p. 177-82, set. 2000. ISSN 0091-3057. Disponível em: <http://www.ncbi.nlm.nih.gov/pubmed/11113498>.

SALUM, C.; ROQUE, A.; MORATO, S. Anxiety-like behavior in rats: a computational model. Neural Netw, v. 13, n. 1, p. 21-9, jan. 2000. ISSN 0893-6080. Disponível em: <http://www.ncbi.nlm.nih.gov/pubmed/10935456>.

SALUM, C.; ROQUE, A.; MORATO, S. Conflict as a determinant of rat behavior in three types of elevated plus-maze. Behav Processes, v. 63, n. 2, p. 87-93, jun. 2003. ISSN 0376-6357. Disponível em: <http://www.ncbi.nlm.nih.gov/pubmed/12763271>.

SCHWARTING, R. K. W.; BORTA, A. Analysis of behavioral asymmetries in the elevated plus-maze and in the t-maze. J Neurosci Methods, v. 141, n. 2, p. 251-60, fev. 2005. ISSN 0165-0270. Disponível em: <http://www.ncbi.nlm.nih.gov/pubmed/15661307>.

SCHWARZ, G. Estimating the dimension of a model. The annals of statistics, Institute of Mathematical Statistics, v. 6, n. 2, p. 461-464, 1978. ISSN 0003-4851. Disponível em: <http://projecteuclid.org/DPubS/Repository/1.0/Disseminate?view=bodyqid=pdf_1\&handle=euclid.aos/1176344136>.

SHANNON, C. E. The Mathematical Theory of Communication. [S.l.]: University of Illinois Press, 1948. 379-423 p. ISBN 0252725468.

TEJADA, J. et al. Characterization of rat behavior in the elevated plus-maze using a directed graph. J Neurosci Methods, v. 184, n. 2, p. 251-5, nov. 2009. ISSN 1872-678X. Disponível em: <http://www.ncbi.nlm.nih.gov/pubmed/19699234>.

TONG, H. Determination of the order of a Markov chain by Akaike's information criterion. Journal of Applied Probability, Applied Probability Trust, v. 12, n. 3, p. 488-497, 1975. ISSN 0021-9002. Disponível em: < http://www.jstor.org/page/termsConfirm.jsp?redirectUri=/stable/pdfplus/3212863.pdf>. 
TREIT, D.; MENARD, J.; ROYAN, C. Anxiogenic stimuli in the elevated plus-maze. Pharmacol Biochem Behav, v. 44, n. 2, p. 463-9, fev. 1993. ISSN 0091-3057. Disponível em: $<$ http://www.ncbi.nlm.nih.gov/pubmed/8446680>.

VOICU, H.; SCHMAJUK, N. Exploration, navigation and cognitive mapping. Adaptative Behaviour, v. 8, p. 207-224, 2000. ISSN 1059-7123. Disponível em: <http://adb.sagepub.com/cgi/reprint/8/3-4/207>.

WALF, A. A.; FRYE, C. A. The use of the elevated plus maze as an assay of anxiety-related behavior in rodents. Nat Protoc, v. 2, n. 2, p. 322-8, 2007. ISSN 1750-2799. Disponível em: <http://www.ncbi.nlm.nih.gov/pubmed/17406592>.

WALLISCH, P. et al. Matlab for Neuroscientists: An Introduction to Scientific Computing in Matlab. Burlington: Academic Press, 2008. ISBN ISBN-13: 978-0-12-374551-4.

WANG, Q. Using genetic algorithms to optimise model parameters. Environmental Modelling and Software, Elsevier, v. 12, n. 1, p. 27-34, 1997. ISSN 1364-8152.

Disponível em: <http://www.sciencedirect.com/science/article/B6VHC-3SWKDHD-4/2|55fcf036a302dbb4e96eee0ce77d45f8>. 